THAIS HAE OK BRANDINI PARK

\title{
O REGIME JURÍDICO DO JURO EM NEGÓCIO FINANCEIRO
}

Dissertação de Mestrado

Orientador: Prof. Dr. José Tadeu De Chiara

FACULDADE DE DIREITO DA UNIVERSIDADE DE SÃO PAULO

São Paulo - SP 
THAIS HAE OK BRANDINI PARK

\section{O REGIME JURÍDICO DO JURO EM NEGÓCIO FINANCEIRO}

Dissertação de Mestrado apresentada como requisito para a obtenção do grau de Mestre na área de concentração de Direito Econômico e Financeiro, sob a orientação do Prof. Dr. José Tadeu De Chiara.

FACULDADE DE DIREITO DA UNIVERSIDADE DE SÃO PAULO

São Paulo - SP 
Banca Examinadora 


\section{DEDICATÓRIA}

Dedico o presente trabalho para todos aqueles que me ensinaram que a verdadeira bênção não está na colheita dos bons frutos, mas na companhia daqueles que nos ajudaram a plantá-los.

Aos meus pais, por todos os discursos, que sempre foram de ensino, por todos os abraços, que sempre foram de carinho, por todas as palavras, que sempre foram de apoio, por todos os gestos, que sempre foram de amor.

Ao Kil, irmão querido que serve de exemplo por sua dedicação e consistência naquilo que faz.

À Tatiane, que não encontra sacrifícios para socorrer-me em qualquer circunstância e, cuja companhia diária foi capaz de suprimir minha saudade de casa.

À Talita, que superando as limitações territoriais, se fez presente a todo momento, não apenas dividindo meus medos, mas os vivenciando comigo.

Ao José Gustavo, que imprime devoção a tudo aquilo que realiza.

Ao João, que destinou algumas de suas preciosas horas para me ensinar metodologia quantitativa, mas também para me acompanhar nos momentos de descanso.

Ao meu querido marido, que pacientemente compreendeu e perdoou a supressão das horas de nosso convívio. Que ouviu, opinou, tornou possível e amou.

À Larissa, minha querida quase-irmã.

À Karina, que incutiu significado a palavra generosa.

À Glaucia, amiga leal e bondosa.

À memória de Amanda, que continua me ensinando o real valor de todas as coisas. 


\section{AGRADECIMENTO}

Agradeço a meu orientador e mestre Prof. Dr. José Tadeu De Chiara, pela oportunidade de realizar o mestrado e, ainda, por todas as horas despendidas em seu escritório e nos encontros informais, que evidenciaram não apenas seu comprometimento com o ensino, sua consistência e honestidade intelectual, mas além, sua gentileza, e generosidade.

Agradeço a contribuição que recebi pelos comentários dos professores José Maurício Conti e Haroldo Malheiros Duclerc Verçosa na argüição de qualificação.

Por fim, agradeço a todos os funcionários da Faculdade de Direito da Universidade de São Paulo, em especial a Márcia e aos bibliotecários: Aurélio, Jair, Margareth, Sônica, Maria Lúcia, Cátia, Gabriela, Ivan, Eduardo, Carolina, Regina, Dona Augustinha e Nilda. 
"Pode afirmar-se sem rodeios: a energia do amor com que um povo está preso ao seu direito e o defende, está na medida do trabalho e dos esforços que lhe custou. Não é o simples hábito, mas o sacrifício, que forja entre o povo e o seu direito a mais sólida das cadeias, e quando Deus quer a prosperidade de um povo, não lhe dá aquilo de que ele necessita, não lhe facilita mesmo o trabalho para o adquirir, mas torna-lho mais duro e mas difícil. Não hesito, pois, em proclamar a este respeito: a luta que exige o direito para desabrochar, não é uma fatalidade, mas uma graça."

(Rudolf Von Ihering) 


\section{ÍNDICE}

LISTA DE FIGURAS..................................................................................................viii

LISTA DE ABREVIATURAS.................................................................................... ix

RESUMO...................................................................................................................... xi

ABSTRACT ..................................................................................................................

INTRODUÇÃ

1. O NEGÓCIO FINANCEIRO.......................................................................... 16

1.1. A ATIVIDADE DE INTERMEDIAÇÃO FINANCEIRA E O NEGÓCIO FINANCEIRO

1.2. O NEGÓCIO FINANCEIRO E A RENDA SOCIAL_...................................... 28

2. INTRODUÇÃO AO OBJETO DE ESTUDO.....................................................34

2.1. JUROS E A NOÇÃO DE PREÇO....................................................................... 34

2.2. BREVE PERSPECTIVA HISTÓRICA.............................................................. 41

3. O REGIME JURÍDICO DO JURO EM NEGÓCIO FINANCEIRO........ 46

3.1. JUROS REMUNERATÓRIOS E JUROS MORATÓRIOS.................................. 46

3.2. JUROS COMPOSTOS E ANATOCISMO: UMA PROBLEMÁTICA DE

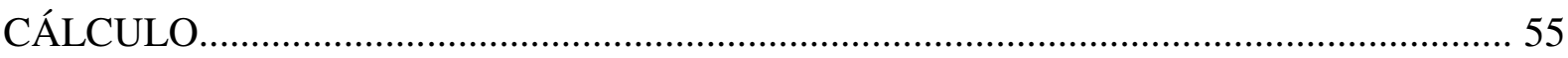

3.3. COMISSÃO DE PERMANÊNCIA...................................................................... 72

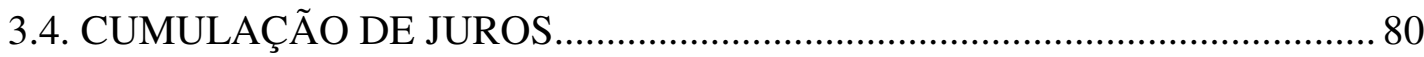

3.5. LIMITAÇÃO DA TAXA DE JUROS.............................................................. 85

4. JUROS E A PERSPECTIVA MACROJURÍDICA............................................ 98

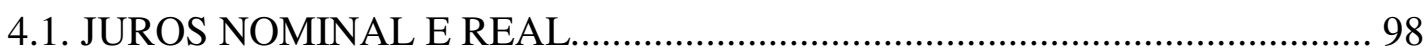


4.2. TAXA BÁSICA DE JUROS E AS PERDAS E DANOS NAS OBRIGAÇÕES EM DINHEIRO .106

4.3. A COBRANÇA DO CRÉDITO TRIBUTÁRIO EM FACE DA TAXA BÁSICA DE JUROS.

4.4. JUROS COMO INSTRUMENTO DE POLÍTICA MONETÁRIA .115

4.5. A FIXAÇÃO DA TAXA BÁSICA DE JUROS E O PROBLEMA DE LEGITIMIDADE

5. CONCLUSÃO .132

REFERÊNCIAS PRIMÁRIAS (JURISPRUDÊNCIA)........................................136

SUPREMO TRIBUNAL FEDERAL (STF)............................................................136

SUPERIOR TRIBUNAL DE JUSTIÇA (STJ)........................................................137

TRIBUNAL DE JUSTIÇA DO ESTADO DE SÃO PAULO (TJ-SP)........................139

TRIBUNAL DE JUSTIÇA DO RIO GRANDE DO SUL (TJ-RS)...........................142

REFERÊNCIAS SECUNDÁRIAS (BIBLIOGRAFIA).....................................143

LIVROS

ARTIGOS, PERIÓDICOS E TRABALHOS PUBLICADOS.....................................147

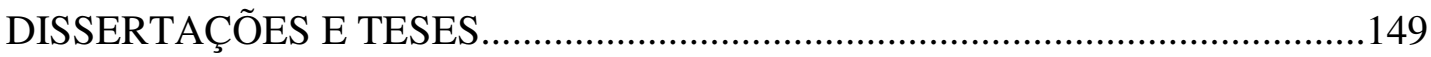

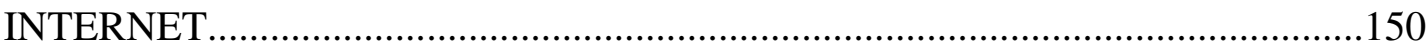




\section{LISTA DE FIGURAS}

FIGURA 1: CÁLCULO DE JUROS SIMPLES................................................................57

FIGURA 2: CÁLCULO DE JUROS COMPOSTOS......................................................57

FIGURA 3: CÁLCULO DE AMORTIZAÇÃO PELO SISTEMA FRANCÊS............59

FIGURA 4: APLICAÇÃo DE JUROS SIMPLES NO CÁLCULO DE AMORTIZAÇÃO FRANCÊS...............................................................................................60

FIGURA 5: APLICAÇÃO DE JUROS COMPOSTOS NO CÁlCULO DE AMORTIZAÇÃO FRANCÊS.............................................................................................60

FIGURA 6: IDENTIFICAÇÃO DE UMA TAXA DE JUROS SIMPLES E UMA TAXA DE JUROS COMPOSTOS NUM EXEMPLO DADO............................................61 


\section{LISTA DE ABREVIATURAS}

ADCT: Ato das Disposições Constitucionais Transitórias

ADIn: Ação Direta de Inconstitucionalidade

Agr: Agravo de instrumento

AgRg: Agravo regimental

Ap: Apelação

art.: artigo

arts.: artigos

Bacen: Banco Central do Brasil

$\mathrm{C}$ : bens e serviços de consumo

C': fluxo da renda aplicada em gastos de consume

DOU: Diário Oficial da União

CAMOB: Caixa de Mobilização Bancária

CDB: Certificado de depósito bancário

CF: Constituição Federal

CMN: Conselho Monetário Nacional

Copom: Comitê de Política Monetária

DPMFi: Dívida Pública Mobiliária Federal Interna

EC: Emenda Constitucional

ED: Embargos de Declaração

EI: Embargos Infringentes

I: bens e serviços de capital

IGP-DI: Índice Geral de Preços - Disponibilidade Interna

IPC: Índice de Preços ao Consumidor

LBC: Letra do Banco Central do Brasil

LFT: Letras Financeiras do Tesouro

Libor: London Interbank Offered Rate

LTN: Letras do Tesouro Nacional

M: quantidade de moeda

MNI: Manual de Normas e Instruções do Banco Central do Brasil 
ORTN: Obrigações Reajustáveis do Tesouro Nacional

P: nível geral de preços

P': fluxo de renda poupada

Pr: Produto social

RDB: Recibo de depósito bancário

RE: Recurso extraordinário

REsp: Recurso especial

Ri: Riqueza disponível

Rs: Riqueza social

SBPE: Sistema Brasileiro de Poupança e Empréstimo

SELIC: Sistema Especial de Liquidação e Custódia

SFH: Sistema Financeiro de Habitação

STN: Secretaria do Tesouro Nacional

Sumoc: Superintendência da Moeda e do Crédito

T: volume físico das transações

$\mathrm{T}^{\prime}$ : trabalho

TJLP: Taxa de juros de longo prazo

TR: Taxa referencial de juros

URV: Unidade Real de Valor

V: velocidade de circulação de moeda 


\section{RESUMO}

PARK, Thais Hae Ok Brandini. O regime jurídico do juro em negócio financeiro. 150p. Dissertação (Mestrado em Direito). Faculdade de Direito, Universidade de São Paulo, São Paulo. 2009.

Este trabalho tem como objetivo analisar o regime jurídico do juro em negócio financeiro e a expressão dos efeitos que se colhem no plano da ordem social. O que se pretende demonstrar é como o direito regula a matéria em face do papel que o juro desempenha no encaminhamento do fluxo monetário, influenciando de maneira decisiva o crédito e, por conseguinte, a atividade produtiva do Estado. Para tanto, dividiu-se o presente estudo num exame do juro sob uma perspectiva micro e macrojurídica. Primeiro, o juro foi apresentado em face da noção de preço, momento em que a análise da especulação como motivação da liquidez revelou que os fluxos monetários em direção aos particulares se ajustam em função da participação do Estado na renda social. Em seguida, foi realizado um estudo detalhado acerca do regime jurídico brasileiro do juro, bem como da limitação dos juros em função dos princípios do equilíbrio econômico-financeiro e da vedação ao enriquecimento sem causa. A última parte do trabalho pretendeu expor a multilateralidade de efeitos decorrente da prática de juros, concluindo-se pela necessidade em se considerar na sua composição sua vertente dinâmica, com exame detalhado da taxa básica de juros e suas peculiaridades. Concluiu-se, portanto, que a manipulação da taxa básica de juros como hoje é feita, a despeito de conformada aos limites dos textos normativos que regulam o sistema financeiro, revela a ilegitimidade da atuação do Estado, decorrente do desvio de função dos mecanismos de controle da moeda e do crédito.

PALAVRAS-CHAVE: regime jurídico, juros, crédito, liquidez, anatocismo, taxa básica de juros, política monetária. 


\begin{abstract}
PARK, Thais Hae Ok Brandini. O regime jurídico do juro em negócio financeiro. 150p. Dissertação (Mestrado em Direito). Faculdade de Direito, Universidade de São Paulo, São Paulo. 2009.

This paper aims to examine the body of law which governs the interest rate in the credit and its effects in social order. The purpose is to demonstrate how the law governs that matter in view of the role played by the interest in conducting the cash flow, influencing the credit and, therefore, the productive activity of the State. Thus, the present study was divided into the examination of interest rate from a micro and a macro legal perspective. First of all, a study of interest rate by the notion of price was presented. At the moment, the analysis of speculation as motivation of liquidity revealed that cash flows towards individuals adjust according to the State's participation in social income. Second, it was conducted a detailed study on the interest rate legal system as well as their limitation imposed by the principles of economic and financial balance and the unjust enrichment. The last part of the work sought to explain the multilateral effects that arise from the practice of interest rate. At the time, it was studied the need to consider the dynamic aspect in the composition of interest rate, with a detailed examination of the SELIC rate and its specificities. Therefore, it was concluded that the management of SELIC rate as is done today, despite conformed to the limits of the law which regulate the financial system, reveals the State's action illegitimacy, resulted from the misuse of the mechanisms of money and credit control.
\end{abstract}

KEYWORDS: body of law, interest rate, credit, liquidity, capitalized interest, basic interest rate, monetary policy. 


\section{INTRODUÇÃO}

Para uma análise adequada do regime jurídico do juro em negócio financeiro e a expressão dos efeitos que se colhem no plano da ordem social, é imprescindível que se faça a distinção do negócio que o fundamenta. Isto porque será em razão deste substrato, e da reformulação de suas funções no percurso da história, que se comporão as funções desempenhadas pelos juros.

Por este motivo é que o trabalho tratará inicialmente do negócio jurídico de crédito, operacionalizado pela atividade de intermediação financeira, que se particulariza em razão da origem de recursos, da natureza de suas prestações e de seu âmbito de eficácia.

Investigando, assim, seus delineamentos, será introduzida em seguida a figura do juro em face da noção de preço, a fim de compreender melhor as alterações legislativas acerca da matéria, bem como os parâmetros em que devem ser fixado seus limites. Como se verá, demonstrar-se-á que o juro desempenha um papel fundamental no encaminhamento do fluxo monetário, influenciando de maneira decisiva o crédito e, por conseguinte, a atividade produtiva do Estado, função esta nem sempre observada quando de sua regulamentação.

Por conseguinte, a opção pelo estudo do juro em negócio financeiro justifica-se em razão da função que desempenha na ordem social, de instrumentar mecanismos de controle de moeda e crédito e, ainda, a situação reclama maior atenção, quando esta função precípua está sofrendo distorções para financiar a estrutura do Estado.

Para tanto, o trabalho utilizou uma metodologia consistente no estudo da bibliografia selecionada e da jurisprudência do Poder Judiciário e dividiu-se na seguinte estrutura: uma análise do juro em negócio financeiro sob uma perspectiva microjurídica, em que se discutiu primordialmente a atividade de intermediação financeira e o negócio financeiro, bem como o regime jurídico brasileiro do juro; e a análise do juro em negócio financeiro sob uma perspectiva macrojurídica, com um estudo do juro em face da multilateralidade de efeitos decorrentes de sua prática. 
É importante deixar assinalado que, quando necessário, o presente trabalho socorreu-se à metodologia quantitativa, sem perder de vista que, à economia cumpre apenas fornecer o exame de como se comportam os fenômenos no plano da ordem social, enquanto que ao direito cumpre regulá-los. Diz-se, pois, que aquela descreve e, este prescreve.

O primeiro capítulo tem por finalidade delinear o negócio jurídico de crédito, com uma análise estrutural do negócio financeiro, a partir da atividade de intermediação financeira, pontuando os principais equívocos que são cometidos ao se confundir o negócio de crédito com o negócio a crédito e o negócio de mútuo. Ainda neste contexto, dedicou-se parte do trabalho a elucidar os efeitos que se colhem na renda social a partir da manipulação deste negócio financeiro, defendendo-se que é a partir do crédito que se operacionaliza a antecipação da renda antes que se altere o produto social e, por conseguinte, que se viabiliza o desenvolvimento da atividade econômica do Estado.

O segundo capítulo apresentou a figura do juro em face da noção de preço, donde se defendeu que sua composição resulta da comparação entre diferentes situações de liquidez, expressa em razão da equivalência entre as disponibilidades monetárias e a preferência pela liquidez e da eficiência marginal dos capitais.

Ainda nesta oportunidade, a especulação como motivação da liquidez revelou que os fluxos monetários em direção aos particulares se ajustam em função da participação do Estado na renda social, o que foi estudado em minúcias no último momento. Finalmente, uma breve perspectiva histórica dos juros foi necessária para evidenciar que suas funções reformularam-se à medida que se reformulavam as funções cumpridas pelo crédito.

O capítulo três tem o intuito de sistematizar o regime jurídico brasileiro do juro, iniciado com a diferenciação entre os juros remuneratórios e moratórios e o regime a que se submetem. Prosseguiu-se com o exame acerca dos juros simples e compostos em face da vedação a prática do anatocismo, onde se defendeu que este, referindo-se a forma de cobrança, não se coaduna àquele, referindo-se a forma de cálculo. Discussão esta inovada com o advento da Medida Provisória 2.170, de 23.8.01 que permitiu a capitalização de juros em período inferior a um ano nos negócios financeiros, momento em que foi defendida sua constitucionalidade. Apresentou-se também uma nova figura de juros remuneratórios, denominado comissão de permanência, discutindo suas peculiaridades. Por 
fim, a análise do juro, sob a perspectiva microjurídica, concluiu-se com um estudo acerca da cumulatividade e limitação em função dos princípios do equilíbrio econômicofinanceiro e da vedação ao enriquecimento sem causa.

O último capítulo pretendeu expor a multilateralidade de efeitos que se colhem decorrente da prática de juros, evidenciando o seu papel no encaminhamento do fluxo monetário. Neste momento, foi analisada, a partir do conceito de juros nominal e real, a necessidade de considerar em sua composição a vertente dinâmica que assegura a equivalência das diferentes situações de liquidez. Com a alteração da legislação que introduziu como parâmetro a taxa de juros para a mora do pagamento de impostos devidos à Fazenda Nacional (art. 406 do Código Civil), conclui-se que a despeito da superação da fixação de juros em termos nominais, a taxa básica, por si só, não basta para resguardar o equilíbrio da relação jurídica.

Outrossim, estudou-se sobre a taxa básica de juros sua estrutura e natureza e, por conseguinte, a impossibilidade de sua cumulação com as perdas e danos, sob pena de configuração do bis in idem, bem como a possibilidade de sua cobrança a títulos de juros moratórios decorrentes do crédito tributário.

Finalmente, a despeito de constatado que ao juro compete desempenhar a função de instrumentar políticas de controle de moeda e de crédito e, conseqüentemente, de orientar a atividade produtiva do Estado, um estudo acerca da fixação da taxa básica de juros no decorrer da história revelou que sua utilização apenas se deu com a finalidade de administrar necessidades de liquidez do Estado, o que provocava seu endividamento, em razão da composição da Dívida Pública. Concluiu-se, portanto, que a manipulação da taxa básica de juros como hoje é feita, a despeito de conformada aos limites dos textos normativos que regulam o sistema financeiro, revela a ilegitimidade da atuação do Estado, decorrente do desvio de função dos mecanismos de controle da moeda e do crédito.

Todas essas razões justificam a relevância do tema enfrentado nessa dissertação, com a tentativa de abordar as principais controvérsias decorrentes da matéria, superando os argumentos que tenham apenas como objetivo impedir a cobrança considerada excessiva dos encargos decorrentes do negócio financeiro, sem que se perquira acerca dos efeitos colhidos na ordem social. 


\section{CAPÍTULO 1. O NEGÓCIO FINANCEIRO}

\subsection{A ATIVIDADE DE INTERMEDIAÇÃO FINANCEIRA E O NEGÓCIO FINANCEIRO}

A análise da atividade de intermediação financeira nos remete ao processo de desmaterialização do instrumento monetário que, no decorrer da história, sofre a sobreposição gradativa de novos mecanismos. Este processo de transformação da moeda resulta da necessidade em se eliminar os inconvenientes dos mecanismos anteriormente utilizados, permitindo que este instrumento cumpra com lealdade suas funções.

Originalmente, as notas de banco eram certificados de depósitos de moeda metálica que davam ao portador direito de reembolso à vista desta quantidade de metal. Todavia, tais notas deixam de ser representativas de moeda metálica e passam a ser representativas de crédito a partir do momento em que são associadas com as operações de desconto de letras de câmbio - pela qual o credor apresentava o documento ao banco, antes de seu vencimento, recebendo seu valor em notas bancárias, ao preço de juro.

Pela primeira vez, as notas bancárias passam a ser criadas sem um encaixe metálico correspondente, condição que cessará quando o devedor reembolsar a letra de câmbio junto ao banco, na data de seu vencimento. ${ }^{1}$

A letra de câmbio, a despeito de utilizada como instrumento de pagamento, transporte de fundos e instrumento de crédito $^{2}$, apresentava os inconvenientes do valor do título corresponder a uma soma referente a operação comercial realizada, variável em função da data de seu vencimento, e não poderia ser transmitida ao portador, bem como dependia da credibilidade de seus sacados, nem sempre conhecidos.

A associação das operações de desconto e emissão das notas de banco não apenas beneficiavam os banqueiros, com o pagamento de juro pela letra de câmbio que

\footnotetext{
${ }^{1}$ Esta operação foi realizada, à primeira vista, pelo banqueiro Johan Palmstruch, em meados do século XVIII, em Estocolmo. HUGON, 1972, p. 39.

${ }^{2} \mathrm{~A}$ possibilidade da letra de câmbio ser transferível por endosso, substituir a transferência dos capitais em moeda metálica e ser antecipada pela operação de desconto, tornou possível sua utilização como instrumento de pagamento, transporte de fundos e instrumento de crédito, respectivamente.
} 
antecipavam, mas os titulares do documento que, com as notas de banco, não precisavam se preocupar com os inconvenientes da letra de câmbio; assim, o público passa a adquirir o hábito de utilizar as notas de banco como instrumento de pagamento.

Contudo, momentos de crise provocavam uma corrida aos bancos para conversão desta nota bancária, o que gerou a necessidade da suspensão provisória de sua conversibilidade: em 1797 na Inglaterra quando em guerra contra a França, em 1866 na França quando em guerra contra a Áustria, em 1872 e 1885 na Rússia quando em guerra contra Turquia e Criméia e, em 1914 com a Guerra Mundial. Finalmente, com a determinação do curso forçado da nota bancária com a Crise de 29, consagrou-se a inconversibilidade deste papel-moeda, dando surgimento a moeda escritural. ${ }^{3}$

Esta moeda escritural fundamenta-se em rendimentos do público que são canalizados para os depósitos bancários, cujas operações de débito e crédito são realizadas por escrituras contábeis feitas nos livros dos bancos, dispensando a necessidade de utilização da moeda física nas transações.

Os depósitos bancários são realizados pelo público não apenas em razão da segurança e comodidade que um banco oferece para conservar e proteger quantias monetárias e facilitar as transações, mas principalmente porque o valor poupado entesourado sem aplicação ${ }^{4}$ não gera frutos, todavia quando confiados às instituições financeiras que os encaminham no sentido do investimento, rendem juro aos depositantes.

Ocorre que não haveria qualquer interesse ao banco receber esses depósitos se tivesse que conservá-los em sua totalidade, pois, se assim o fosse, sua função reduzir-se-ia apenas à substituição de um instrumento monetário por outro, sem que pudesse utilizá-lo para render frutos e, conseqüentemente, remunerar o capital dado em depósito.

Por este motivo e, tendo em vista que a experiência bancária revelou que nem todos os depositantes buscam ao mesmo tempo levantar os valores dado em depósito, os bancos passaram a utilizar estes valores para conceder empréstimos ao público, conservando em seu poder apenas parte dos depósitos.

\footnotetext{
${ }^{3}$ HUGON, 1972. p. 45.

${ }^{4}$ Rendimento superior ao dispêndio conservado sem que seja utilizado no sentido do investimento. Vide capítulo 2.1.
} 
Exemplificativamente, considerando que a proporção de depósito e encaixe deva ser de $20 \%$ (vinte por cento) e, considerando um único banco recebendo um depósito inicial de R \$ 1.000.000,00, conservará R \$ 200.000,00 e emprestará R \$ 800.000,00. Ocorre que o valor dado em empréstimo também será canalizado em depósito bancário, pois os pagamentos compensam-se em operações de entrada e saída de dinheiro do caixa bancário, de maneira que receberá este banco novo depósito no importe de $\mathrm{R} \$ 800.000,00$, dos quais conservará $\mathrm{R} \$ 160.000,00$ e emprestará R \$ 640.000,00. Este ciclo repetir-se-á novamente, com o retorno em depósito de $\mathrm{R} \$ 640.000,00$ e a conservação de $\mathrm{R} \$ 128.000,00$ em encaixe e a concessão de um novo empréstimo de $\mathrm{R} \$ 512.000,00$. Assim temos que, neste dado momento, a partir dum depósito inicial de $\mathrm{R} \$ 1.000 .000,00$, terá o banco concedido em empréstimo R $\$ 1.952 .000,00(800+640+512) .^{5}$

Este será o fundamento da atividade de intermediação financeira que, portanto, operacionaliza-se a partir da existência de agentes superavitários, que canalizam seus rendimentos superiores a seus dispêndios a agentes deficitários, orientando opções de consumo ou investimento, num mecanismo de efeito multiplicador da moeda.

Nota-se que os empréstimos concedidos por um banco geram depósitos em outros bancos, de maneira que seus próprios depósitos também advêm em grande parte de empréstimos concedidos por outros bancos. Desta forma, enquanto o depósito inicial não houver sido resgatado, sempre haverá novos depósitos correspondentes nos livros de outros bancos e, a manutenção de contas destas instituições junto ao Banco Central faz com que estes débitos e créditos sejam liquidados sem a necessidade dos pagamentos em espécie.

Assim, a criação de moeda fundamenta-se na concessão de empréstimos de instrumento monetário recebido em depósito, e cumpre-se através de um sistema de registro contábil junto às instituições financeiras, que pressupõe o instrumento monetário desempenhando sua função por força das normas jurídicas e a aceitação do crédito como instrumento de pagamento, a partir das operações bancárias. ${ }^{6}$

A atividade de intermediação financeira, portanto, é a prática da concessão de crédito das instituições financeiras, a partir dos depósitos bancários, por um mecanismo multiplicador de moeda, que coloca seus tomadores em situação de liquidez. Nesta forma 
de contratação, o tomador, num primeiro momento, se coloca numa situação jurídica de devedor para, futuramente, contratar outro negócio de crédito na situação jurídica de credor.

No discurso do Direito, o crédito que decorre da atividade de intermediação financeira é comumente confundido com o crédito decorrente das operações mercantis e, com o negócio jurídico de mútuo cuja disciplina está prevista nos arts. 586 a 592 do Código Civil.

José Tadeu De Chiara, superando esta problemática, diferenciou o negócio de crédito do negócio a crédito, "in verbis":

"Nas operações mercantis, em que o preço não é resgatado no ato pelo adquirente, o seu valor é que se constitui em ativo de comerciante, e é em função dele que este exerce o direito de crédito contra o devedor. Diferenciase do crédito decorrente do empréstimo de dinheiro, em razão do qual ocorre a entrega da posse e propriedade da moeda que assim é livremente disponível pelo mutuário. Em relação ao crédito em sentido comercial, este se consubstancia na escrituração do comerciante pelo registro contábil indicado em "contas a receber", e resulta de um contrato acessório. A um negócio principal no âmbito do qual se defere prazo para o devedor efetuar pagamento em moeda, o crédito aparece como uma forma acessória que viabiliza o negócio principal. Caracteriza-se assim pela dação de crédito em favor do comprador. Daí decorre, na maioria dos casos, a geração de efeitos comerciais que se encaminham para o sistema bancário com o propósito de investirem os comerciantes na situação de liquidez. necessária à regular operação de sua empresa. Na segunda hipótese, isto é, o crédito decorrente do empréstimo de moeda ocorre a investidura dos devedores diretamente na situação de liquidez. O devedor, uma vez instrumentado por moeda pode atuar nos mercados adquirindo bens e serviços, independentemente de qualquer vinculação com outro negócio em relação ao credor." 7 
Donde se extrai que negócio financeiro (negócio de crédito) e negócio mercantil (negócio a crédito) se particularizam principalmente no tocante a: a) origem dos recursos; b) natureza das prestações; c) âmbito de eficácia.

Em primeira ordem de consideração, consoante origem dos recursos, o crédito mercantil consubstancia-se no negócio jurídico a prestações, de maneira que o comerciante opta pela entrega da mercadoria ou prestação do serviço antes de adimplido todo o pagamento do preço.

Por conseguinte, ao estabelecer que o adimplemento dar-se-á em pagamentos sucessivos, o empresário está concedendo, pois, prazo para o cumprimento da contraprestação, renunciando sua própria liquidez, motivo pelo qual é forçoso concluir que, nos negócios a crédito, os recursos financeiros que o operacionalizam são de origem própria do concedente.

No negócio financeiro isto não se observa, isto é, para a atividade de intermediação financeira, as instituições financeiras buscam junto ao público os recursos financeiros que usarão para concessão de empréstimos que instrumentalizarão consumo e investimento no mercado.

A despeito da enunciação do art. 17 da Lei $n^{\circ}$ 4.595/1964, que inclui na atividade de coleta, intermediação e aplicação financeira os recursos financeiros próprios, esta atividade de concessão de crédito operacionaliza-se a partir de recursos financeiros de terceiros, uma vez que sua origem fundamenta-se nos rendimentos dos agentes superavitários encaminhados aos depósitos bancários.

Neste sentido, posicionou-se o Tribunal Federal de Recursos da $2^{\mathrm{a}}$ Região:

"Ora, a realização de empréstimos, com meios próprios e sem captação de recursos de terceiros, não se pode equiparar às atividades especificas das instituições financeiras, que consistem, como expresso no texto legal, na 'coleta, intermediação ou aplicação de recursos financeiros próprios ou de terceiros'. O traço característico das chamadas financeiras é a captação de recursos do público 
em geral para investimentos financeiros, cujos resultados são atribuídos aos respectivos subscritores. " 8

Apenas seria possível admitir o contrário, que a atividade de intermediação financeira tem recursos próprios como origem, considerando que recursos financeiros quando recebidos tornar-se-iam próprios, diante da impossibilidade em se devolver o mesmo bem dado em empréstimo, pois trata-se o instrumento monetário de bem fungível.

Ainda, conforme elucidou Eduardo Salomão Neto, não apenas implicaria na indistinção das instituições financeiras para com as demais entidades que coletam, intermediam e aplicam recursos financeiros próprios, bem como seria forçoso pressupor que a captação antecederia a coleta e a aplicação. ${ }^{9}$

${ }^{8} \mathrm{HC}$ 2555/ES (citado por SALOMÃO NETO, EDUARDO. Atividade privativa de instituição financeira. Ob. cit., p. 38).

9 "A definição de instituição financeira dada pelo artigo 17 da Lei $n^{\circ} 4.595 / 64$ é desmesuradamente ampla e, e interpretada literalmente, em seu sentido puramente gramatical, poucas atividades escapariam da reserva aberta em favor das assim chamadas instituições financeiras. De fato poucas são as atividades que não envolvem a coleta, intermediação ou aplicação de recursos próprios ou de terceiros.

Todas as empresas aplicam no mercado financeiro os recursos coletados através do exercício de sua atividade, emprestando-os, como forma de manter o valor e obter rentabilidade sobre seu capital de giro. Ao fazerem isso, estariam intermediando a aplicação de recursos, acessoriamente a sua atividade principal, e deveriam - pela estrita interpretação do artigo 17 da Lei $n^{\circ} 4.595 / 64$ - ser consideradas instituições financeiras. $O$ mesmo ocorre sempre que uma empresa capta empréstimos para pagar salários ou adiantamento de salários de funcionários, ou que uma sociedade capta recursos junto ao público investidor através da emissão de debêntures ou ações.

Por outro lado, existem também empresas que empreendem a coleta, intermediação ou aplicação de fundos como atividades principais, sem que isso as equipare, segundo mostra o senso comum, a instituições financeiras. Assim, por exemplo, uma administradora de imóveis tem o encargo de cobrar aluguéis dos imóveis que administra, captando-os e repassando-os aos proprietários, sem ser instituição financeira. Já sociedades corretoras e distribuidoras de títulos e valores mobiliários também têm sua atividade centrada na aplicação de recurso de seus clientes nos mercados financeiros e de capitais, sem serem instituições financeiras. Isso é, de resto, reconhecido pela própria legislação, na medida em que se faz necessária a equiparação de sociedades corretoras e distribuidoras a instituição financeira para que a elas se apliquem as regras sobre intervenção e liquidação extrajudicial, criadas pela Lei $n^{\circ}$ 6.024, de 13 de março de 1974 para as instituições financeiras em geral. Essa equiparação se contém no artigo 52 da Lei $n^{\circ} 6.024 / 74$ e evidentemente não seria necessária se as sociedades corretoras e distribuidoras fossem instituições financeiras.

Das considerações aduzidas é forçoso concluir que a interpretação literal do artigo 17 da Lei $n^{\circ}$ 4.595/64 levaria a conclusões absurdas, como a de considerar como privativas de instituição financeira as atividades desempenhadas por boa parte das empresas nacionais, senão por todas elas. Uma solução lógica para a questão poderia ser fornecida por uma interpretação mais elaborada do dispositivo em questão. Essa interpretação se baseia no fato de que a lei menciona 'coleta, intermediação ou aplicação de recursos financeiros próprios ou de terceiros'. Ora, é impossível coletar recursos próprios, não ser no sentido de que quaisquer recursos obtidos a partir de operações de captação se tornam próprios quando recebidos, já que o mútuo implica transferência de propriedade (artigo 1.257 do Código Civil). Por outro lado, haveria coleta de recursos de terceiros quando o recebimento de recursos pelo intermediador se desse em caráter fiduciário, como ocorre na administração de fundos em condomínio. Isso significa que a coleta preliminar é sempre pressuposta em relação à aplicação de recursos. Assim, a própria literalidade do artigo 17 deixaria espaço a se concluir que o dispositivo pressupõe também em relação à aplicação o mesmo que pressupõe em 
Insta salientar que o presente trabalho não compartilha da exposição de Eduardo Salomão Neto, em relação ao argumento de que os recursos seriam próprios tendo em vista o negócio de mútuo implicar em transferência de propriedade. É importante registrar, neste momento, que o negócio de crédito não se confunde com o negócio de mútuo, o que será analisado ao final do presente capítulo.

No tocante ao segundo aspecto, isto é, quanto à natureza das prestações, também se diferenciam os negócios em questão. No negócio mercantil há diferimento de prestação e contraprestação, que se cumpre pela entrega de bem diverso (instrumento monetário por mercadoria ou serviço), sendo o crédito apenas a prestação pela qual se viabiliza o negócio contratado.

No negócio financeiro, todavia, prestação e contraprestação firmam-se no fornecimento de instrumento monetário, pois a instituição financeira empresta moeda, devendo o tomador do crédito restituí-la na data avençada ao preço de juro. ${ }^{10} \mathrm{O}$ tomador do crédito, portanto, se investe na situação de liquidez, podendo adquirir bens e serviços disponíveis no mercado, sem estar adstrito à relação de crédito contratada.

Esta consideração tem particular relevância, visto que introduz a noção da bilateralidade e multilateralidade dos negócios de crédito e a crédito, consoante o terceiro aspecto pelo qual se diferem: o âmbito de eficácia. ${ }^{11}$

$\mathrm{Na}$ forma inferior de troca os bens ou serviços desejados pelas partes consubstanciam a própria prestação e contraprestação sem que se faça presente o instrumento de troca. Assim, têm-se duas prestações assegurando a satisfação imediata da necessidade das partes, com a troca daquilo que cada qual possua precisamente com aquilo que cada qual procura.

relação à coleta: a captação de recurso preliminar e cumulativa” ... "Em vista disso, deve-se interpretar o artigo 17 da Lei $n^{\circ}$ 4.595/64, que define as instituições financeiras em função de suas atividades privativas, como exigindo, cumulativamente, (i) captação de recursos de terceiros em nome próprio, (ii) seguida de repasse financeiro através de operação de mútuo, (iii) com o intuito de auferir lucro derivado da maior remuneração dos recursos repassados em relação à dos recursos coletados, (iv) desde que a captação seguida de repasse se realize em caráter habitual." Ibid., p. 23-38.

${ }_{10 ، " C h a m a m o s}$ operações financeiras aquelas nas quais ambas as partes se obrigam a realizar prestação em moeda ou em crédito; comerciais são aquelas nas quais uma das partes, pelo menos, se obriga a prestar serviços ou a transferir bens diferentes da moeda e do crédito." VIDIGAL, 1977, p. 193.

${ }^{11}$ A bilateralidade e multilateralidade a que se refere dizem respeito ao plano de eficácia dos negócios jurídicos, e não ao plano da existência concernente à composição subjetiva do suporte fático, de maneira que serão levados em consideração os direitos e deveres irradiados em razão do contrato. 
Entretanto, na forma superior instrumentada por moeda, a troca é substituída por duas operações, de venda e de compra, com a entrega do bem ou serviço desejado por uma das partes, e a entrega de moeda por outra parte. Aquele que recebeu o instrumento monetário buscará junto ao mercado a satisfação de sua necessidade, entregando por sua vez moeda, em troca de bem ou serviço. Nesta forma superior, portanto, enquanto uma das prestações assegura a satisfação imediata da necessidade humana, outra assegura apenas esta satisfação no futuro. ${ }^{12}$

As considerações acerca da forma superior de troca evidenciam que a moeda permite a seu titular exercitar direitos de cunho patrimonial sem restrição, com a aquisição de qualquer bem ou serviço, desde que esteja sendo ofertado no mercado: "O dinheiro dálhe uma latitude ilimitada (quanto a tempo, lugar, pessoas e extensão). Portanto o dinheiro não satisfaz imediatamente às necessidades, mas dá a certeza absoluta, e que todo o mundo aceita, de poder satisfazê-las ulteriormente."13

Quer-se dizer com isso que a presença do instrumento monetário nas relações jurídicas confere peculiaridade de efeitos: das funções de intermediação de troca, de reserva de valor e de padrão de valor inerentes a moeda, decorrem as funções por ela desempenhadas na ordem social de liquidez e procura efetiva, isto porque a moeda, não apenas permite e instrumenta a relação de troca, figurando denominador comum entre bens e serviços passíveis de serem adquiridos no mercado, mas recebe pelo ordenamento jurídico a qualidade de descrimine para o exercício de direitos.

Assim, diante da situação de titularidade de instrumento monetário, o sujeito pode optar por conservar a moeda para uma satisfação futura, preservando sua situação de liquidez, ou por utilizá-la adquirindo bens e serviços, exercitando a procura efetiva.

Desta forma, tendo em vista as funções de liquidez e procura efetiva e a força liberatória do instrumento monetário conferida pelo ordenamento jurídico - pelo qual se viabiliza a liberação de vínculos obrigacionais de cunho patrimonial - é possível que seu titular se relacione com todos os agentes do mercado, influenciando e sofrendo influência de decisões de consumo e investimento já exercitadas, sem que esteja adstrito a relação de crédito contratada.

\footnotetext{
${ }^{12}$ JHERING, 19-? p. 121-123.

${ }^{13}$ Ibid., p. 121.
} 
É o estudo do Direito Econômico, sob o aspecto macrojurídico, que informa os efeitos multilaterais decorrentes do negócio financeiro, conforme preleciona Eros Roberto Grau:

"O que marca definitivamente a distinção entre os tratamento micro e macrojurídico é o objeto a que se refere a norma ou o conjunto de normas jurídicas. Assim, alinha-se como objeto do tratamento microjurídico a unidade de atividade e de sujeito, ao passo que o tratamento macrojurídico tem como objeto agregados de atividades e de sujeitos."... "Outro aspecto relevante a anotar - que reforça sobremaneira as justificativas da utilização do critério do micro e do macrojurídico, ao menos como artifício metodológico, para as analises de Direito Econômico - está em que, em regra, as normas microjurídicas são construídas em torno dos sujeitos de direito, ao passo que as macrojuridicas são elaboradas em torno do exercício de determinadas atividades." 14

Esta especificidade de multilateralidade de efeitos não se observa no negócio mercantil, porque o crédito que compõe o direito que será exercido em face do devedor diz respeito ao valor do preço que não foi adimplido à vista e, portanto, está adstrito a esta relação contratual. Seu titular não poderá exercitar as inúmeras opções no mercado, senão a referente ao contrato que deu azo ao crédito mercantil.

Assim, o negócio a crédito apenas irradia seus direitos e deveres para as partes que o compuseram, por este motivo, seu âmbito de eficácia é restrito. Diferentemente, o negócio de crédito atribui situação de liquidez ao titular do instrumento monetário, conferindo-lhe possibilidade de relacionar-se com todos agentes do mercado, onde se faz presente a multilateralidade dos efeitos irradiados por este negócio.

Com efeito, esta multilateralidade também não é característica do contrato típico de mútuo descrito nos arts. 586 a 592 do Código Civil, do qual também se difere o negócio jurídico de crédito.

${ }^{14}$ GRAU, Eros Roberto, 1981, p. 20-30. 
Conforme já exposto, o negócio de crédito é outorga de disposição de dinheiro de outrem, visto que as instituições financeiras intermediam recursos a partir dos depósitos bancários, enquanto que o mútuo é outorga de disposição de dinheiro próprio.

Outrossim, enquanto no negócio financeiro a instituição disponibiliza recursos monetários, nem sempre com a efetiva entrega da moeda, para existência do mútuo é necessária a tradição da coisa cuja posse e propriedade foi transferida, pois se trata de contrato real ${ }^{15}$. No contrato de mútuo, o credor ao receber o bem, toma emprestado, enquanto que no contrato de crédito, o credor ao utilizar a quantia, exerce sua pretensão do crédito. A operação de crédito não tem por finalidade o empréstimo de dinheiro nos termos do contrato de mútuo previsto pelo Código Civil, tem a finalidade de suprir recursos monetários para instrumentar opções de consumo ou investimento.

Sinalizando este entendimento, Pontes de Miranda, ao diferenciar o mútuo quanto à abertura de crédito, esclarece: "o mútuo supõe entrega, ou promessa de bem fungível. A abertura de crédito supõe promessa de atender a levantamentos.", outrossim quanto ao contrato de desconto: "no mútuo há dação do bem fungível e o nascimento do crédito contra o mutuário. No desconto, o descontatário cede crédito e o que recebe é contraprestação da cessão do crédito", finalmente, quanto ao adiantamento bancário: "no adiantamento bancário, há, de regra, a permissão de restituição parcial, o que, no mútuo, só existe se houver cláusula nesse sentido". ${ }^{16}$

Indo mais além, certo é que o substrato do negócio de mútuo há de se coadunar aos princípios que constituem o alicerce da teoria clássica contratual: o princípio da autonomia da vontade, da força vinculante e da relatividade das convenções do contrato. Donde se colhe que às partes é permitido contratar, no limite da lei, se tornando obrigatórias suas convenções, sem que seus efeitos aproveitem ou prejudiquem terceiros.

Ocorre que, em se tratando do negócio jurídico de crédito, tais noções clássicas não se aplicam. Sobre estas novas formas de configuração de contrato no âmbito das operações de crédito, José Tadeu De Chiara enumera suas principais peculiaridades: i) conteúdo

\footnotetext{
${ }^{15}$ "No direito brasileiro, o mútuo é contrato real: exige, para ser, o elemento "entrega da coisa”. A entrega da coisa, aí, não é elemento necessário à validade do contrato, nem à sua eficácia; é elemento necessário à sua existência." MIRANDA, Pontes de. Tratado de Direito Privado. Parte Especial. Tomo XLII. Ob. cit., p. 08.

${ }^{16}$ Ibid., p. 25-28.
} 
básico predeterminado; ii) cláusulas regulamentares impostas por entidades estranhas ao negócio jurídico; iii) contratos de compulsória celebração; iv) contratos que não podem inovar no contrato originário do qual derivam. ${ }^{17}$

A expressão "fins econômicos", disposta pelo art. 591 do Código Civil, não quer se referir a negócio jurídico de crédito. A metodologia quantitativa nos socorre informando que, no âmbito do ciclo de produção temos atividades de produção, circulação, distribuição e consumo, sendo apenas as três primeiras destinadas a fins econômicos. Quer-se dizer com isso que o art. 591 refere-se aos contratos de mútuo destinados a produção, circulação e distribuição de bens e serviços, excluindo-se, pois, aqueles destinados ao consumo.

Donde se colhe que no mútuo para fins econômicos (contratado com finalidade de produção, circulação e distribuição de bens e serviços) serão os juros remuneratórios presumidos no limite da taxa que estiver em vigor para a mora do pagamento de impostos devidos à Fazenda Nacional.

Ainda, no discurso do Direito, cumpre observar que o mútuo é o contrato mediante o qual se empresta coisas fungíveis e, portanto, motiva-se em razão dos frutos jurídicos a que o principal irá dar causa. Os frutos civis, sempre hão de ter valor econômico, ainda que sua utilidade seja abstrata ${ }^{18}$, motivo pelo qual todos os contratos de mútuo são econômicos.

Essa particularização do negócio jurídico de crédito, ou negócio financeiro, é imprescindível para o presente estudo, tendo em vista que em se tratando da matéria de juros, os efeitos jurídicos que se colhem divergem quando decorrentes do negócio financeiro, do negócio mercantil, ou do negócio de mútuo.

Enquanto os juros nos contratos a crédito em que são inseridos a cláusula de pagamento a prestações são apenas elemento da formação do preço, em se tratando do negócio financeiro as funções por ele desempenhadas se particularizam.

Com efeito, não se pode perder de vista que a análise do regime jurídico do juro realizada pelo presente trabalho refere-se apenas àqueles decorrentes dos negócios de crédito ou negócio financeiro, cujo conceito elucidou José Tadeu De Chiara:

\footnotetext{
${ }^{17}$ CHIARA, José Tadeu de. Operações de credito: disciplina das obrigações. Revista de Direito Público, São Paulo, v. 49/50, p. 303-311, 1979.

${ }^{18}$ MIRANDA, Pontes de. Tratado de Direito Privado. Parte Geral. Tomo III. Ob. cit., p. 75.
} 
"Dessa forma, entendemos por operação de crédito a conjugação sistemática de negócios jurídicos de natureza cambiária ou contratual, por intermédio de instituição financeira, pela qual se realiza suprimento de recursos monetários para instrumentar consumo ou investimento". ${ }^{19}$

Todavia, é necessário assinalar que a instituição financeira é própria parte do negócio jurídico de crédito, pois a ela compete coletar e intermediar os recursos de terceiros em direção ao consumo ou investimento, motivo pelo qual a conjugação sistemática dos negócios jurídicos de crédito não se realiza por intermédio mas sim pela própria instituição financeira. Desta forma, o conceito adequar-se-ia com precisão apenas com a supressão do vocábulo 'intermédio’.

O negócio financeiro, portanto, tem seu substrato jurídico no contrato ou título de crédito, e compreende inúmeras modalidades inerentes a complexidade das operações bancárias que implica no surgimento de novas relações decorrentes desta atividade. Desta forma, a natureza jurídica do negócio financeiro coaduna-se com o instrumento jurídico que compõem seu substrato: se fundado em negócio de natureza contratual, fica a ressalva dos elementos que lhe são peculiares, se fundado em negócio de natureza cambiária regerse-ão pelos princípios da literalidade, cartularidade e autonomia.

Conclui-se, portanto, que o negócio de crédito: i) é objeto da atividade de intermediação financeira; ii) pela qual se realiza suprimento de recursos monetários para instrumentar consumo ou investimento; iii) a partir de recursos tomados junto ao público; iv) consubstanciado num negócio de natureza contratual ou cambiária; v) no qual prestação e contraprestação cumprem-se pelo fornecimento de moeda; vi) figurando como parte, de um lado, a instituição financeira e, de outro, o tomador do crédito; vii) que colhe efeitos para além da relação jurídica contratada, interferindo em todo o conjunto da sociedade.

\footnotetext{
${ }^{19}$ CHIARA, José Tadeu de. Operações de credito: disciplina das obrigações. Revista de Direito
} Público, São Paulo, v. 49/50, p. 303-311, 1979. 


\subsection{O NEGÓCIO FINANCEIRO E A RENDA SOCIAL}

No negócio financeiro, os efeitos colhidos para alem da relação jurídica bilateral são reflexo da prerrogativa que o titular do instrumento monetário tem de realizar novos atos de comércio jurídico ${ }^{20}$, interagindo com elementos da produção social.

O poder de compra da moeda, expressado pela sua função de liquidez e procura efetiva, encerra a possibilidade de interferência legítima do titular da moeda em relação ao conjunto de toda a sociedade. Este conjunto da sociedade se expressa em função de sua atividade econômica, ou seja, como resultado de uma força de trabalho aplicada a recursos naturais disponíveis, mediante utilização de equipamentos existentes.

Vidigal $^{21}$ enuncia que o resultado do processo econômico pode ser apreciado de duas formas: tanto pela forma física, aferindo o resultado da aplicação do trabalho numa riqueza disponível pelo conjunto de bens e serviços produzidos, quanto pela forma monetária, aferindo tal resultado pelo conjunto das remunerações monetárias de tais bens e serviços participantes desta produção.

Esta segunda forma de apreciação é possível tendo em vista que, numa economia monetária, todos os fatores econômicos são remunerados em moeda, ou seja, uma vez que o exercício de direitos de cunho patrimonial é instrumentalizado por moeda, todo o processo da atividade de produção se desenvolve mediante pagamento. Assim temos salários como a remuneração do trabalho, lucro como a remuneração do capital industrial, juros como a remuneração do capital, aluguéis como a remuneração dos recursos naturais, e os royalties como a remuneração da tecnologia.

Donde se extrai que, considerando a expressão física do processo econômico, teremos que uma dada força de trabalho (T') aplicada às riquezas disponíveis (Ri) gera um conjunto de todos os bens e serviços resultantes da atividade econômica, chamado produto social (Pr).

\footnotetext{
${ }^{20}$ Comércio jurídico é a organização da satisfação de todas as necessidades humanas por meio do salário. JHERING, 19-? p. 100.

${ }^{21}$ VIDIGAL, 1973, p. 106.
} 
Por sua vez, considerando a expressão monetária do processo econômico, teremos que uma dada força de trabalho ( $\mathrm{T}^{\prime}$ ) aplicada às riquezas disponíveis (Ri) gera um conjunto de remunerações monetárias dos fatores produtivos, ao longo do processo de produção, chamado renda social (Rs).

Ainda nos ensinamentos de Vidigal $^{22}$, a análise do produto social é uma situação estática, qual seja, dos bens e serviços considerados fisicamente, que podem destinar-se a satisfação imediata de uma determinada necessidade ou à utilização no processo produtivo. Portanto, 'Pr' compõe-se de bens e serviços de consumo (C) e bens e serviços de capital (I).

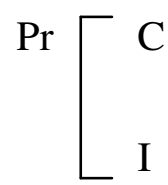

A análise da renda social, por sua vez, é dinâmica, pois representa o fluxo da renda que se aplicará a gastos de consumo ou permanecerá em poupança sem utilização. Portanto, 'Rs' compõe-se de gastos de consumo (C') e poupança (P').<smiles>[R][CH-][PH2+]</smiles>

Examinando os elementos deste processo, percebemos que produto social (Pr) e renda social (Rs) são apenas formas distintas de se expressar o resultado da atividade econômica - física e monetariamente, de maneira que devem forçosamente representar um mesmo valor, ou seja, $\operatorname{Pr}=$ Rs.

Outrossim, uma vez que a produção econômica se ajusta em razão da demanda, certo é que os bens e serviços de consumo ajustar-se-ão aos gastos de consumo, donde se conclui que $\mathrm{C}=\mathrm{C}^{\prime}$. Tem-se assim que, se $\mathrm{Rs}=\mathrm{Pr}$, e C = C', conseqüentemente $\mathrm{I}=\mathrm{P}$ '. Assim, tudo aquilo que não foi gasto com bens e serviços de consumo, será gasto com bens e serviços destinados a utilização do processo produtivo. 
Todavia, esta igualdade $\left(\mathrm{P}^{\prime}=\mathrm{I}\right)$ não se observa. Não há uma relação de equivalência necessária entre os que poupam e os que investem. Isto porque as decisões de poupar e de investir são tomadas por grupos diferentes de indivíduos. ${ }^{23}$ Nos ensinamentos de Vidigal, a formação da poupança se dá em função da propensão a consumir, visto que se compõe pela renda social não gasta em bens e serviços de consumo, enquanto que o investimento se forma em função dum conjunto de qualidades que compõem a disposição empresarial. Esta disposição empresarial, como será analisada em seguida, decorre das motivações de liquidez.

A análise da acomodação de poupança e investimento tem relevância na medida em que o Direito regulamenta e condiciona os mecanismos que possam orientar a renda social não consumida em direção aos bens e serviços de investimento, no âmbito da atividade produtiva do Estado. Para tanto, cumpre ressaltar que a riqueza doméstica não se identifica com a riqueza social. ${ }^{24}$

Para o indivíduo, a poupança constitui riqueza em si mesma, ou seja, tudo aquilo que não foi gasto com consumo implicará em enriquecimento, sem importar que esta renda excedente tenha sido ou não aplicada. O contrário ocorre com a riqueza social. $\mathrm{O}$ entesouramento não representa riqueza para o conjunto da sociedade, que apenas restará configurada se este excedente for aplicado no sentido do investimento. ${ }^{25}$ Quer-se dizer com isso que a não aplicação da poupança em investimento não interfere na riqueza doméstica, entretanto interfere na riqueza social:

"Suponha-se que, simultaneamente, toda a humanidade decidisse entesourar, em baús, em colchões, em gavetas, a metade de suas rendas de fator. Os assalariados guardariam metade de seus salários, os titulares de recursos naturais e de capitais a metade de suas rendas e juros, os empresários a metade de seus lucros. Aparentemente, todos deviam enriquecer-se, pelas poupanças que todos realizam. Ocorre, no entanto, que o total das rendas sociais equivale ao total do produto social: em outras palavras, se metade das rendas sociais se entesouram, então metade do produto social não encontrará comprador. (...) na medida em que a

\footnotetext{
${ }^{23}$ GUDIN, 1956, p. 18.

${ }^{24} \mathrm{O}$ termos 'riqueza social' foi empregado aqui significando todo o produto social excedente ao consumo que será aplicado na atividade econômica do Estado.

${ }^{25}$ Investimento é a adição a toda espécie de equipamento de capital resultante das atividades produtivas. KEYNES, 1982. p. 72.
} 
atividade social se reduzir, na medida em que o desemprego avultar, diminuirá o quantum do trabalho social aplicado à riqueza existente - e porque decresceram os fatores, decrescem os resultados. Cairão, assim, o produto social e a renda social: e, porque todos pretenderam enriquecer-se entesourando, todos se empobrecem.",26

Como então fazer com que a renda poupada se reverta no sentido do investimento? Para responder esta pergunta, três considerações preliminares são necessárias: i) para que haja investimento, é necessário haver um excedente de produção sobre o consumo; ii) este excedente ao consumo há de ser aplicado em novas combinações de meios produtivos; iii) apenas a alteração no processo de produção implica em desenvolvimento.

Em primeiro lugar, faz-se necessário o excedente de produção sobre o consumo, uma vez que, numa sociedade em que a produção seja apenas suficiente para atender o consumo, os recursos obtidos pela produção se esgotariam. Assim, teríamos que o produto social seria idêntico aos bens e serviços destinados a satisfação das necessidades humanas, sem que se obtivessem bens e serviços destinados a utilização no processo de produção.

Em segundo lugar, este excedente deve ser aplicado em novas combinações de meios produtivos, pois do contrário estaríamos diante do entesouramento da renda social poupada, implicando no empobrecimento da sociedade.

Por fim, apenas a alteração no processo de produção traduz o desenvolvimento econômico. Este apenas se verifica quando causado um distúrbio de equilíbrio neste processo, uma vez que só assim será possível colher no futuro bens e serviços distintos aos atuais e, por conseguinte, alterar a composição do produto social. ${ }^{27}$

Assim, há três maneiras para fazer com que o fluxo de renda seja aplicado no processo de produção: investimento direto do próprio titular da poupança, pela aplicação da poupança em participação societária, e pela concessão de crédito em favor dos que necessitem de parcelas da renda social para viabilizar decisões de investir. ${ }^{28}$

\footnotetext{
${ }^{26}$ VIDIGAL, 1973, p. 116.

${ }^{27}$ SCHUMPETER, 1961, p. 131.

${ }^{28}$ CHIARA, José Tadeu de. A moeda e a ordem jurídica. Ob. cit., p. 89.
} 
O que interessa ao presente trabalho é o mecanismo decorrente da atividade de intermediação financeira, cujo aspecto macrojurídico colhe efeitos no âmbito da atividade econômica do Estado, os demais mecanismos, seja do investimento direto pelo titular da poupança (onde se incluem negócio mercantil e negócio de mútuo), seja pela aplicação em participação societária, não serão analisados.

Disse-se que o negócio de crédito se operacionaliza a partir dos depósitos bancários, mediante a atividade de intermediação financeira que investe em situação de liquidez seus tomadores, aos quais se possibilita o exercício da procura efetiva em todo o conjunto social. Desta forma, as quantias monetárias poupadas que, a princípio ficariam sem aplicação junto aos depósitos bancários, são dadas em empréstimos para aqueles que necessitem de parcelas da renda social.

É, portanto, o crédito que, sem prejuízo ao consumo, cria o excedente necessário ao investimento. Observe-se, porém que, antes mesmo dos bens e serviços produzidos pela atividade econômica do Estado serem remunerados, os tomadores de crédito já ampliaram sua renda social, donde se conclui que o negócio financeiro antecipa o resultado do produto social, permitindo a ampliação da renda (em sua forma monetária), antes da alteração no conjunto de bens e serviços de capital (em sua forma física) pela atividade econômica do Estado.

Sob a óptica do direito, num primeiro momento, temos uma organização jurídica necessária para assegurar ao credor os meios necessários de forçar o devedor a honrar seus compromissos, garantindo segurança suficiente para que o público opte canalizar seus recursos em depósitos bancários, bem como para que os bancos optem emprestar certa soma em dinheiro, ao preço de juro.

Num segundo momento, são as normas jurídicas que revelam, por um lado, os condicionamentos dos mecanismos de crédito, estabelecendo instrumentos com a finalidade de encaminhar poupança ao investimento e, por outro lado, a participação do Estado na disputa pela poupança disponível. ${ }^{29}$

Desta forma, quanto aos instrumentos condicionados pelo ordenamento jurídico que orientam opções de investimento, a taxa de juros será estudada como expressão da

\footnotetext{
${ }^{29}$ CHIARA, José Tadeu de. A moeda e a ordem jurídica. Ob. cit., p. 89.
} 
equivalência entre diferentes situações de liquidez e, quanto à participação do Estado na renda social não consumida, a taxa de juros será estudada como determinante do motivo especulação da preferência pela liquidez. 


\section{CAPÍTULO 2. INTRODUÇÃO AO OBJETO DE ESTUDO}

\subsection{JUROS E A NOÇÃO DE PREÇO}

A compreensão, no conhecimento comum, que a palavra preço encerra está relacionada àquilo que se paga em unidade monetária para aquisição de um bem ou serviço. Conforme ensina Jhering ${ }^{30}$, o salário (empregado aqui como o elemento que torna possível a redução de todas as necessidades humanas em um único denominador comum), no direito positivo recebe nomes específicos: tratar-se-ia de preço, em sentido estrito, a contraprestação em moeda fornecida nos contratos de venda; de aluguel a fornecida nos contratos de locação; de salário a fornecida nos contratos de serviço e; finalmente, de juros a fornecida nos contratos de empréstimo.

Assim, não só as doutrinas econômicas, bem como as jurídicas, justificam os juros como o preço do capital. Carvalho de Mendonça ${ }^{31}$ elucida que: "o juro é o preço do uso do capital e um prêmio do risco que corre o credor" e, seguindo as orientações de Jhering esclarece "é o aluguel do dinheiro, como a renda, ou o aluguel, é o preço do uso da coisa no contracto de locação"; Ascarelli ${ }^{32}$ e Pontes de Miranda ${ }^{33}$ explicam como a renúncia da liquidez e renda do capital, sob o aspecto econômico, respectivamente e, como fruto civil, sob o aspecto jurídico; Vidigal ${ }^{34}$ como "o preço da liquidez".

Contraprestação - o que se paga em moeda a título de preço, aluguel, salário e juros - e prestação - venda, locação, serviço e empréstimo - compõem a finalidade última de assegurar a satisfação das necessidades humanas que, neste caso, contrapõem-se.

Se as relações jurídicas permeadas pelo elemento preço, em se tratando do negócio financeiro, são celebradas num contexto em que uma das partes objetiva conceder

\footnotetext{
${ }^{30}$ JHERING, 19-? p.123.

${ }^{31}$ MENDONÇA, 1956, p. 81-82.

32، La dotrina economica più recente, avvisa appunto nella perdita di liquidità che consegue ala sostituzione al danaro (universale strumento di scambio) di un altro bene, la spiegazione generale del fenomeno dell'interesse.D'altra parte è appunto da un lato la mancanza di um rutto naturale del danaro, dall'altro la circonstanza che il bene di ottenuto contro danaro può constituire un bene di consumo, quanto spiega la naturale ostilità Allá liceitá degli interessi in un'economia precapitalistica, nella quale il mutuo di danaro è innazi tutto volto a sovvenire esigenze di consumo del mutuatario" ASCARELLI, 1959. p. 575-577.

${ }^{33}$ MIRANDA, Pontes de. Tratado de Direito Privado. Parte Especial. Tomo XXIV. Ob. cit., p. 15.

${ }^{34}$ VIDIGAL, 1977, p. 203.
} 
empréstimo de moeda, e outra objetiva tomar empréstimo se colocando numa situação de liquidez, há que se inferir que para a verificação de preço é necessária a diversidade de interesses (enquanto um busca maximizar a quantidade da moeda que lhe será retornada como contraprestação, outro procura minimizá-la).

Nas lições de Von Jhering ${ }^{35}$, preço é vocábulo próprio das relações de intercâmbio, pois pressupõe a diversidade de interesses, afastando-se, pois, dos contratos de comunhão de escopo, o que colhe relevante conseqüência no plano da regulamentação jurídica.

Quando se fala em contratos de comunhão de escopo, as partes se reúnem para contribuir para uma mesma finalidade, na qual a verificação de vantagem para uma delas significa necessariamente vantagem para as demais. Em face do objetivo comum, não há que se falar em contraposição de interesses.

Os contratos de intercâmbio, por seu turno, pressupõem a reciprocidade entre as obrigações do negócio, de maneira que a vantagem de um se contrapõe a de outro: enquanto um quer adquirir a maior soma possível de moeda, outro quer despender a menor soma possível. Nestas relações é que se faz presente o elemento de egoísmo a que Jhering faz menção. ${ }^{36}$

É a partir do elemento de egoísmo, que impulsiona cada particular a associar-se, buscando ao máximo a realização de sua vantagem e conveniência, que se valida a noção do equivalente:

"O equivalente vem a ser o equilíbrio entre a prestação e a contra-prestação, estabelecida pela experiência adquirida do comércio jurídico consoante o valor dos bens e das prestações."... "É a experiência que estabelece esse equilíbrio entre a prestação e a contraprestação, e fixa uma taxa do salário (da prestação real), graças ao qual as duas partes adquirem o seu direito, sem perda tanto para uma como para a outra. O equivalente

${ }^{35}$ JHERING, 19-? p. 125-130.

36“"A fixação do salário para cada caso particular, é da competência do consentimento individual. $O$ direito reconhece aqui o poder regulador, e legítimo, do egoísmo. A sua concepção é esta: - cada uma das duas partes tem em vista a sua própria conveniência, e procura aproveitar-se da situação menos favorável da outra."... "O egoísmo daquele que quer alcançar o mais possível, choca-se contra idêntico sentimento do que procura dar o menos possível. O equilíbrio que se produz em tal ponto de indiferença, é que é o equivalente." Ibid., p. 125. 
realiza a idéia de justiça no domínio em que se move o comércio jurídico."37

A noção de equivalência, aplicada à formação da taxa de juros, entretanto, não se restringe à noção de equivalência de um negocio de intercâmbio, ou seja, à contraposição dos interesses bilaterais. Isto porque o instrumento monetário implica na ampla possibilidade de exercitar direitos de cunho patrimonial em toda ordem social e, conforme já exposto, não se limita ao negócio contratado, colhendo efeitos multilaterais.

Nos ensinamentos de José Tadeu De Chiara ${ }^{38}$, o equivalente compreendido na composição da taxa de juros decorre da comparação entre diferentes situações de liquidez, ou seja, em face de todas as alternativas de decisões possíveis tendo por base a quantidade total de moeda disponível.

Donde se colhe duas implicações: a) o juro expressa-se em razão da equivalência entre as disponibilidades monetárias e a preferência pela liquidez; b) a preferência pela liquidez orienta-se em conformidade à eficiência dos capitais.

Para compreensão do comportamento das disponibilidades monetárias, nos socorremos à equação de Fisher $^{39}$, expressada pela igualdade entre montante de pagamentos e montante de transações:

$$
\mathrm{MV}=\mathrm{PT}
$$

Onde $\mathrm{M}$ é quantidade de moeda em circulação; V, velocidade de circulação desta moeda e, portanto, a expressão do número médio de vezes em que o instrumento monetário muda de possuidor num determinado período de tempo; $\mathrm{P}$, nível geral de preços e $\mathrm{T}$, volume físico das transações, expresso no comércio jurídico de bens e serviços para a satisfação das necessidades humanas.

Neste contexto, desenvolveram-se explicações acerca dos motivos que fariam variar cada elemento que compõem a equação e, com a associação da teoria monetária

\footnotetext{
${ }^{37}$ Ibid., p. 125.

${ }^{38}$ CHIARA, José Tadeu de. A moeda e a ordem jurídica. Ob. cit., p. 138.

${ }^{39}$ FISHER, 1926.
} 
(equação de Fisher) à teoria da formação de preços (lei da oferta e procura), Wicksel foi o primeiro autor a defender que a taxa de juros seria o fator responsável por equilibrar a poupança e o investimento.

Distinguindo a taxa de juros praticada no mercado (preço que efetivamente se paga pelo aluguel do dinheiro) e a taxa de juros natural ou normal (decorrente da eficiência marginal do capital estabelecidas se as transações fossem feitas in natura), esclareceu que se àquelas situarem-se abaixo destas, provocar-se-á um aumento na procura de bens e serviços de consumo, seja em razão da diminuição do estímulo a poupança - já que forçosamente terá baixado a taxa que os bancos pagam a seus depositantes - seja em razão da oportunidade de lucro dos empresários - uma vez que pagarão juros mais baixos em relação ao rendimento do capital. ${ }^{40}$

Não sendo objetivo deste trabalho sanar as controvérsias decorrentes da teoria econômica acerca do comportamento da renda social em razão da taxa de juros ${ }^{41}$, o que cumpre deixar anotado é que o juro se perfaz em face das disponibilidades monetárias.

Assim, não necessariamente basta apenas uma taxa de juros baixa para reduzir ou aumentar a poupança social, mas sendo certo, contudo, que a manipulação deste mecanismo colherá efeitos no plano da ordem social, como se verá.

Esta equação, portanto, é expressão dos efeitos que se colhem em razão da interferência sobre qualquer de seus elementos. O número de vezes em que a unidade monetária é utilizada em transações de qualquer espécie, multiplicada pela quantidade de moeda em circulação é o que determinará o preço em relação ao volume das transações.

No tocante à preferência pela liquidez, Keynes, ao analisar a dinâmica da utilização da moeda nos mercados, esclarece que a liquidez, motiva-se em razão da renda, do negócio, da precaução e da especulação. O motivo renda é aquele que leva o titular a conservar a moeda como disponibilidade imediata para suas necessidades em razão do hiato de tempo compreendido entre o recebimento e o desembolso da renda; o motivo

\footnotetext{
${ }^{40}$ WICKSEL (citado por GUDIN, 1956, p. 194).

${ }^{41}$ Hayek, Mises e Myrdall acompanhavam Wicksell no tocante a influência que a taxa de juros exercia sobre o sistema econômico. Cassel, por sua vez, observava que não necessariamente uma diminuição na taxa de juros acarretaria uma redução na economia, enquanto Keynes esclarecia que o sistema econômico variava em função da taxa de juros e, além, da propensão ao consumo e da eficiência marginal do capital. GUDIN, 1956, p. 26-37.
} 
negócio por necessidade de giro, garantindo a renda entre o intervalo de compra e de realização; ainda, o motivo precaução para manter recursos líquidos para atender contingências inesperadas como oportunidade extraordinária para obter ganho de forma imediata ou em curto espaço de tempo; e por fim o motivo especulação para buscar a melhor alternativa num conjunto de relações disponíveis no mercado, adquirindo vantagem em razão do custo de conservação em face do custo de segurança. ${ }^{42}$

Em última análise, especular significa realizar o negócio jurídico com o máximo de vantagem que se possa obter. Há, assim, dois aspectos que influenciam a alteração da motivação especulativa: as variações na taxa de juros decorrentes da disponibilidade monetária e a presença da autoridade monetária nas operações de mercado livre, indicando o sentido da política monetária que determina o encaminhamento da renda social. ${ }^{43}$

Com efeito, as instituições financeiras optarão por encaminhar seus depósitos em direção aos particulares, para concessão de crédito, ou em direção ao Estado, para subscrever títulos públicos, em razão da taxa de juros mais atrativa que revelará a especulação como motivo de liquidez.

Daí que, para a especulação, a presença do Estado na atividade de intermediação financeira é decisiva. É a partir do nível percentual em que o Estado se dispõe a tomar recursos que os particulares se ajustam, de maneira que os mecanismos que sinalizam a política monetária e de crédito determinarão tomadas de decisões das instituições financeiras no sentido de conceder crédito ou subscrever títulos públicos.

Esta análise revela que o Estado não apenas concorre com a retirada de recursos da poupança social, mas, por conseguinte, utiliza o crédito como mecanismo para viabilizar esta retirada em maior ou menor grau. Neste sentido, a administração pública reformulouse paulatinamente para desempenhar estas novas funções, tanto no âmbito estrutural, com criação de novos órgãos para exercer o mecanismo do controle do crédito, quanto no âmbito conjuntural, editando regras de direito sob os critérios da especialidade e da velocidade exigidos pela matéria (vide capítulo 4.4$){ }^{44}$

\footnotetext{
${ }^{42}$ KEYNES, 1982, p. 229.

${ }^{43}$ CHIARA, José Tadeu de. A moeda e a ordem jurídica. Ob. cit., p. 27.

${ }^{44}$ Ibid., p. 101.
} 
Assim temos que o Estado atua: i) sobre a economia como agente regulador da atividade econômica, estabelecendo normas de comportamento compulsório para os demais agentes (atuação por direção) e dinamizando instrumentos de intervenção conforme as leis que regem o funcionamento dos mercados (atuação por indução) e, ii) na economia como agente econômico, controlando meios de produção (atuação por absorção) ou participando deste controle (atuação por participação). ${ }^{45}$

Portanto, o juro expressa-se em razão da equivalência entre as disponibilidades monetárias e a preferência pela liquidez; donde conclui-se que i) as disponibilidades monetárias e os preços comportam-se em conformidade à relação MV = PT; ii) que a preferência pela liquidez motiva-se em razão da renda, do negócio, da precaução e da especulação; iii) que o motivo especulação revela a participação do Estado como autoridade monetária direcionando o fluxo da renda social.

Finalmente, resta salientar ainda que a preferência pela liquidez orienta-se em conformidade à eficiência dos capitais. Esta consideração tem relevância na medida em que o nível de investimento dependerá da relação entre escala da eficiência marginal do capital e taxa de juros.

Esclarece Keynes ${ }^{46}$ que a eficiência marginal do capital é a relação entre a renda esperada de uma unidade adicional (investimento ou obtenção de um bem de capital) e seu custo de produção. Como esta eficiência vai variar em razão de uma expectativa de renda e do preço de oferta corrente do bem de capital, ela dependerá do preço de retorno que se espera obter do dinheiro investido, num bem recentemente produzido. Se o investimento sobre aquele capital aumenta, aumenta, portanto, sua demanda e, por conseguinte seu preço de oferta, o que fará elevar seu custo de produção e, conseqüentemente, diminuirá a eficiência marginal do capital.

É neste contexto que a taxa de juros se coloca como elemento indispensável para orientar decisões no sentido do investimento. Será o juro o responsável por orientar a expectativa de renda esperada da unidade adicional do capital. $\mathrm{O}$ investimento vai variar até aquele ponto da demanda em que esta eficiência coincida com a taxa de juros do

\footnotetext{
${ }^{45}$ GRAU, 2001.

${ }^{46}$ KEYNES, 1982, p. 229.
} 
mercado, evidenciando seu papel fundamental no encaminhamento do fluxo monetário e, por conseguinte, na atividade produtiva do Estado.

A noção de equivalência, portanto, em se tratando da formação da taxa de juros, se perfaz não apenas quando vislumbrada restritivamente ao patrimônio das partes envolvidas no negócio jurídico. Isto porque ele se compõe inclusive em relação às opções de mercado, bem como em razão de interesses de ordem pública.

Assim, consoante a prática de juros, o equivalente se completa a) pelo interesse da coletividade (que no âmbito individual traduz o sentimento de egoísmo que orienta a opção de buscar da melhor forma a satisfação de sua necessidade em condições vantajosas); b) pelas relações de mercado (decorrente das disponibilidades monetárias, da preferência pela liquidez e da eficiência marginal dos capitais); c) pelo tempo ${ }^{47}$; e d) pela participação do Estado na renda social.

A problemática está justamente em se assegurar ao concedente do instrumento monetário a sua preservação em face da flutuação do poder de compra inerente a moeda, bem como das instabilidades do mercado, sem prejuízo de se estipular uma taxa limite que garanta ao tomador do crédito não sofrer abusos decorrentes do negócio celebrado.

Donde se conclui que a disciplina jurídica do juro deve adequar-se de forma a assegurar o equilíbrio constante do preço pela renúncia a liquidez, enquanto perdurar o negócio e, além, em função dos mecanismos de controle da moeda e do crédito, levando em consideração toda a atividade econômica do Estado.

${ }^{47}$ “O equilíbrio nesses casos entre prestação e contraprestação deve ser considerado em termos dinâmicos tanto no momento da constituição do vínculo entre os interessados, como ao longo do período durante o qual deva perdurar." CHIARA, José Tadeu de. A moeda e a ordem jurídica. Ob. cit., p. 114. 


\subsection{BREVE PERSPECTIVA HISTÓRICA}

A regulamentação da prática de juros, desde sua condenação na Antiguidade Clássica, à sua autorização nos dias contemporâneos, adequou-se às exigências da época. A contrariedade sobre o assunto desponta à época da Antiguidade (em Roma e Grécia, notoriamente $\left.{ }^{48}\right)$.

Os egípcios praticavam os juros desde que não superiores ao importe do capital principal dado em empréstimo; os hebreus praticavam apenas com os estrangeiros, e não entre si, os espartanos estavam proibidos de emprestar a juros, por força da legislação de Lycurgo; os atenienses sempre o praticavam sem limite de taxa; todavia, os católicos sempre entenderam que o empréstimo haveria de ser gratuito. ${ }^{49}$

Naquela ocasião, as pessoas apenas emprestavam para satisfazer suas necessidades de consumo, portanto, os empréstimos limitavam-se ao socorro dos necessitados. Sem que houvesse a possibilidade do capital emprestado render frutos ao tomador, uma vez que não era utilizado para aquisição de bens e serviços de capital, o crédito não significava ao mutuário possibilidade de lucro, motivo pelo qual a prática de juros era condenada. ${ }^{50}$

Assim, os juros eram tidos como antinatural, pois nada mais seriam que dinheiro oriundo do dinheiro, cobrados a custa de outrem, conforme se manifestou Aristóteles:

"Pero, como antes se ha dicho, es principalmente la naturaleza quien tiene que suministrar los recursos, ya que es missión de la naturaleza proveer de alimento a los seres que nascen: todos ellos se nutren, em efecto, del resíduo de aquello de que se originam. Por eso la crematística que opera com los frutos de tierra y com los animales es siempre natural. Ahora bien, la crematística tiene, como hemos dicho, dos formas: uma la del comercio al por menor y outra la de la economia doméstica, esta última necessaria y laudable, y la de cambio justamente censurada (pues no es natural, sino a costa de otros); y com tanta más razón se aborrecerá la usura, porque em ella la ganância se obtiene

\footnotetext{
${ }^{48}$ GUDIN, 1956, p. 59.

${ }^{49}$ MENDONÇA, 1956, p. 77-78.

${ }^{50}$ VIDIGAL, 1977, p. 201.
} 
del mismo dinero y no de aquello para lo que este se invento, pues el dinero se izo para el cambio, y em la usura el interes por si solo produce más dinero. Por eso se llama em griego tokos, pues lo endengrado (tiktómena) es de la misma naturaleza que sus generadores, y el interes viene a ser dinero de dinero; de suerte que de todas las clases de tráfico éste es más antinatural."

$\mathrm{Na}$ Idade Média, as teorias teológicas explicavam que o juro era o preço do tempo e, que o tempo pertencia a Deus, motivo pelo qual não se poderia permitir sua prática. Santo Thomás de Aquino explicava que receber juros por empréstimo de dinheiro é vender aquilo que não se tem, donde se conclui sua proibição. O Alcorão também trazia expressa, em diversas passagens, sua proibição. ${ }^{52}$

A própria expressão “juros onzenários”, utilizada para designar juros usurários, originou-se com a Lei das Doze Tábuas, que vedava o lucro superior a uma onça ("uncia" duodécima parte da libra romana), oportunidade em que o mútuo era denominado "unciarium foenus". 53

Enquanto a proibição à prática de juros fundamentava-se, por um lado, nestas teorias teológicas, que interpretavam como antinatural os frutos do dinheiro, por outro lado, fundamentava-se na concepção jurídica que o empréstimo implicava a transferência da propriedade ao mutuário, não podendo render juros em proveito daquele que não tem domínio da coisa. ${ }^{54}$

Entretanto, na Idade Média, com o aumento da população, a intensificação da procura por mercadorias estrangeiras, a criação de rotas comerciais e o início das vendas por atacado nas feiras organizadas em centros comerciais, os empréstimos passam a instrumentar opções de investimento.

${ }^{51}$ ARISTÓTELES, 19-? p. 288.

52"“A usura não é somente uma infração penal, como um pecado perante o Alcorão, que registra estes preceitos: - (Cap. II, v. 276) - "Deus permitiu a venda, proibiu a usura. Aqueles que voltarem para a usura serão entregues ao fogo, onde ficarão eternamente." Mas o v. 125 do capítulo III é mais incisivo: - "Ó crentes! Não vos deis à usura, elevando a quantia ao dobro e sempre ao dobro." Por fim o capítulo XXX esclarece: - "v. 38. O dinheiro que dais a juros para o aumentardes com o bem dos outros, não aumentará perante Deus.". ALTAVILA, 1987, p. 105.

${ }^{53}$ SCAVONE, 2003, p. 31.

${ }^{54}$ ASCARELLI, 1959, p. 577. 
Desta forma, ainda quando proibidos, o desenvolvimento da economia medieval reclamava uma dinâmica de mercado em que fosse possível colher efeitos de juro, o que implicou na criação de modalidades de negócios jurídicos que assegurassem tal resultado: a) a realização de um contrato de depósito com a obrigação de devolução de um quis pluris; b) a realização de um contrato de empréstimo infrutífero, conjuntamente com um contrato de arrendamento, no qual o mutuário pagava um prêmio superfaturado que incorporava os juros do empréstimo; c) a realização de contratos de câmbio simulados pela compensação que representava o pagamento de juros; d) contratos de compra e venda simulada ou superfaturada com juros inseridos no preço. ${ }^{55}$

No início do séc. XVIII, a teoria do metal como conceito de riqueza passa a ser substituída pela teoria da moeda como instrumento de progresso econômico e, por conseguinte, o instrumento monetário passa a ser encarado como instrumento da industrialização, para servir o comércio.

É este "espírito do capitalismo", que valoriza a aquisição econômica como fim em si mesmo e não como meio de satisfazer as necessidades, que passa a orientar os novos comportamentos no mercado. Viabiliza-se a partir do reconhecimento de virtudes humanas em função da utilidade que possam representar para o indivíduo: a honestidade, a pontualidade no pagamento, a laboriosidade, tudo isso para conferir a credibilidade necessária ao bom relacionamento do sujeito no mercado. A intensa religiosidade combinada com o sentimento mercantilista, à época, compunha um "ethos" necessário para que a não observância aos mandamentos econômicos representassem a própria violação do dever cívico. ${ }^{56}$

Esta nova ordem que se instalava baseada na divisão do trabalho, na industrialização, no crescimento da produção e na moeda como instrumento de troca, exigia o rápido fluxo monetário, sustentado pelos empréstimos tomados junto às bancas de comércio, mediante uma compensação.

É neste clima que os estudos que seguem acerca dos juros, flexibilizam a possibilidade da sua cobrança, “in verbis” Montesquieu:

\footnotetext{
${ }^{55}$ BRAVO (citado por SCAVONE, 2003, p. 34-35).
}

${ }^{56}$ WEBER, 2000. 
"O dinheiro é o símbolo dos valores. É óbvio que o que tem necessidade deste símbolo deve alugá-lo, como faz com todas as coisas de que pode ter necessidade. (...) é, na verdade, ação mui elogiável emprestar a outrem dinheiro sem juro; sente-se, porém, que isso só pode ser um conselho de religião, e não uma lei civil (...). Para que o comércio possa ser bem feito, é necessário que o dinheiro tenha um preço $^{, 57}$

Foi assim que a prática do juro caminhou até suas primeiras autorizações, a partir do século XVIII. Foi regulamentado pela primeira vez na Inglaterra ${ }^{58}$, posteriormente França $^{59}$, seguida da admissão de sua prática por alguns países baixos ${ }^{60}$.

O desenvolvimento das novas teorias fundamentou-se, num primeiro momento, na constatação de que o empréstimo não mais era destinado essencialmente a transações necessárias para o devedor garantir seu próprio consumo, mas sim, para fins produtivos, com a aquisição de bens e serviços que seriam posteriormente revendidos com margem de lucro para empresas industriais.

Num segundo momento, a justificativa para a prática do juro fundamentou-se no preço a ser cobrado pelo empréstimo, pois implicaria ao concedente a renúncia de sua liquidez e ao devedor a possibilidade de escolher utilizar este capital para investimento ou consumo, rendendo ou não frutos. ${ }^{61}$

No séc. XIX o juro passa a ser visto como mecanismo capaz de orientar os recursos financeiros, com a fixação em taxas inaceitáveis para os tomadores que se supusessem menos produtivos, orientando as poupanças para o financiamento daqueles que mereciam a

${ }^{57}$ MONTESQUIEU, 1945, p. 35.

58،"Uma "lei contra a usura" aprovada na Inglaterra dizia: "Sendo a usura pela palavra de Deus estritamente proibida, como vício dos mais odiosos e detestáveis... ... que nenhuma pessoa ou pessoas de qualquer classe, estado, qualidade ou condição, por qualquer meio corrupto, artificioso ou disfarçado, ou outro, emprestem, dêem, entregue ou passem qualquer soma ou somas de dinheiro... ... para qualquer forma de usura, aumento, lucro, ganho ou juro a ser tido, recebido ou esperado, acima da soma ou somas emprestadas... ... bem como da usura... ... e ainda da punição de prisão.”. R.H.TAWNER; E. POWER (citado por HUBERMAN, 1973, p. 46).

${ }^{59}$ “Vieram depois os economistas do mesmo século XVIII e o terreno ficou preparado para o Decreti da Assembléia Nacional Franceza, que, a 12 de Outubro de 1789, declarou livre o juro do emprestimo de dinheiro." MENDONÇA, 1956, p. 81.

${ }^{60}$ ASCARELLI, 1959, p. 580.

${ }^{61}$ Ibid., p. 579. 
confiança dos emprestadores, e a distribuição de créditos de forma a permitir a seleção dos investimentos. $^{62}$

Finalmente, com a consagração da atividade de intermediação financeira, e a percepção de que o crédito antecipa o produto social, ampliando a renda, os juros passam a ser vistos sob uma perspectiva de ordem pública.

A alteração na regulamentação da matéria revela que, no decorrer da história, a função dos juros reformulou-se à medida que se reformulava a função do crédito. Desde a época em que os empréstimos eram realizados apenas para socorrer necessidades de consumo, e o juro reduzia-se a mero lucro do emprestador; a época em que o crédito passa a instrumentar investimento, e o juro começa a ser visto como o mecanismo para encaminhar fluxos monetários; aos dias atuais, em que o crédito é percebido como o instrumento capaz de interferir na atividade econômica do Estado e os juros passam a ser fixados em função do controle da moeda e do crédito. 


\section{CAPÍTULO 3. O REGIME JURÍDICO DO JURO EM NEGÓCIO FINANCEIRO}

\subsection{JUROS REMUNERATÓRIOS E JUROS MORATÓRIOS}

Classificam-se os juros, quanto à natureza, em remuneratórios e moratórios. O juro remuneratório é a recompensa pela renuncia da liquidez, e decorre do uso e fruição do capital que foi dado em empréstimo. São os juros devidos desde a contratação até o vencimento da obrigação.

Este juro, também chamado juro de interesse, tem natureza jurídica de fruto civil, pois se traduz em proveito econômico derivado do capital principal. Os frutos hão sempre de ter valor econômico ${ }^{63}$, visto que é em razão deles que se realiza o negócio jurídico de crédito.

No negócio financeiro, prestações e contraprestações se instrumentalizam pelo fornecimento de instrumento monetário, de forma que o capital principal, bem como os juros dele decorrentes, serão operacionalizados por moeda, a despeito do conceito 'fruto civil' compreender todo bem, desde que fungível.

Cumpre salientar, entretanto, que os frutos civis do capital (também ditos jurídicos), decorrem das pretensões de crédito e não do dinheiro com que se satisfazem essas pretensões. Quer se dizer com isso que o crédito que o concedente exercita contra o tomador é que renderá juros, pondo-se o dinheiro que se pague pelo capital emprestado em seu lugar. ${ }^{64}$

Em sendo proveitos resultantes de se haver dado a outrem o uso e fruto do capital, os juros sempre serão prestações acessórias e, portanto, consubstancia-se em coisa do mesmo gênero que o principal e não subsiste se extinta ou inválida a obrigação principal, ou seja, o crédito financeiro (art. 184 do Código Civil).

\footnotetext{
${ }^{63}$ MIRANDA, Pontes de. Tratado de Direito Privado. Parte Geral. Tomo III. Ob. cit., p. 75.

${ }^{64}$ Ibid., p. $85-86$.
} 
Esta consideração tem relevância, na medida em que o Novo Código Civil extirpou a regra geral de que "accessio cedit principali", cuja previsão encontrava-se em seu Projeto, como parágrafo único do art. 92. Sob a égide do antigo diploma legal - Código Civil de 1916, o acessório apenas não seguiria a sorte do principal em caráter excepcional, quando previsão expressa da lei.

Hodiernamente, contudo, a regra geral inverteu-se no tocante às pertenças, donde se extrai, por força do art. 94 deste diploma que, a regra geral tornou-se excepcional, e o acessório apenas seguirá a sorte do principal quando resultar da lei, da manifestação de vontade, ou das circunstâncias do caso.

Em relação aos demais bens acessórios, o Código Civil calou-se, donde se extrai que consoante os frutos, produtos, benfeitorias e acessões o princípio segundo o qual "accessio cedit principali" continua em vigor. Neste sentido já pronunciou o Tribunal de Justiça do Estado de São Paulo:

"Conforme a regra constante no art. 94, segundo a qual os negócios relativos ao bem principal não abrangem as pertenças, salvo se o contrário resultar da lei, da manifestação de vontade, ou das circunstâncias do caso. Logo, não se aplica, em relação às pertenças, a regra de que o acessório segue a sorte do principal, pelo menos no que diz respeito aos negócios de alienação do principal." 65

Por conseguinte, em sendo os juros fruto civil, restarão ligados ao principal, o contrário apenas em caráter excepcional.

Nesta oportunidade, cumpre salientar que, apesar do caráter de acessoriedade dos juros remuneratórios, em se tratando de contrato de poupança, decidiu a jurisprudência que, tendo em vista tais frutos agregarem-se ao capital, haverão de ser considerados obrigação principal, perdendo, pois, seu caráter de acessório. Isto ocorre porque, uma vez que satisfeita a pretensão do crédito com o recebimento dos juros, não há mais que se falar

\footnotetext{
${ }^{65}$ São Paulo, Tribunal de Justiça, Agr 1170899- 0/6.
} 
em fruto, pois desprendido da coisa que lhe originou, deixando os juros de serem juros, mas sim principal. $^{66}$

Pontes de Miranda pontuou as conseqüências da acessoriedade dos créditos de juros, quais sejam: a) somente há créditos de juros enquanto há crédito do principal; b) há de se tratar de crédito; c) o pagamento antes da prestação da quantia principal é contraprestação pela promessa de mútuo e não propriamente crédito de juros; d) o não cumprimento pela promessa de crédito de juros pelo tomador da quantia isenta o promitente dos juros legais e convencionais, ressalvado ao que emprestaria a quantia ação por inadimplemento do pacto; e) a decretação de nulidade, anulação, rescisão ou resolução ex tunc do negócio principal prejudica o crédito de juro, que não se produz; f) se ineficaz o negócio jurídico do crédito principal, não se criam os créditos dos juros; g) a resolução $e x$ nunc do negócio principal irradia créditos de juros até o momento não alcançado pela resilição; h) não se irradiam créditos de juros após a compensação; i) o crédito de juros nasce ao cessionário, na cessão de crédito, e ao sucessor, na sucessão causa morte; j) o contraente pode estabelecer crédito de juro em favor de terceiro; k) o pagamento antecipado da obrigação principal gera o dever de indenizar o credor pela perda de juros a que se contava. ${ }^{67}$

A despeito do que diz acerca da liquidação antecipada do débito, certo é que com o advento do Código de Defesa do Consumidor, e tendo em vista o julgamento da ADIN 2.591/DF na qual o Supremo Tribunal Federal entendeu estarem sujeitos os serviços prestados por entidades do Sistema Financeiro Nacional ao referido diploma legal, não há que se questionar o dever de indenização ao credor pelos juros e encargos a que se contava, em razão da liquidação antecipada do débito.

Hoje, a cobrança de tarifa de quitação antecipada, à inteligência dos art. 52, §2 combinado com art. 42, parágrafo único, do Código de Defesa do Consumidor, enseja a devolução em dobro do importe daquele que tomou o empréstimo. ${ }^{68}$

66“"os juros remuneratónos e a correção monetária, que não se enquadram no conceito de prestação acessória ou renda, porque claramente constituem o capital, porquanto a ele se integram para o cálculo do período seguinte". São Paulo, Tribunal de Justiça, Ap 7.256.658-6. 35.

${ }^{67}$ MIRANDA, Pontes de. Tratado de Direito Privado. Parte Especial. Tomo XXIV. Ob. Cit., p. $34-$

\footnotetext{
${ }^{68}$ São Paulo, Tribunal de Justiça, Ap. 755791900.
} 
Como os juros são bens acessórios que se produzem periodicamente, podem separar-se do capital principal sem lhe alterar ou diminuir a substância. Assim, por se tratarem de elementos dissociáveis, imputar-se-á o pagamento primeiro no juros vencidos e, depois no capital, salvo estipulação em contrário, ou se o credor passar a quitação por conta do capital, conforme dispõe o art. 354 do Código Civil.

No negócio jurídico financeiro a razão para a imputação do pagamento nos juros e, apenas posteriormente no capital, é clara. O proveito econômico decorrente do rendimento do capital como finalidade do negócio de crédito traduz-se nos juros, de maneira que a imputação ao principal antes de seus acessórios reduziria seu proveito.

Todavia, nos casos em que haja estipulação expressa em sentido contrário, ou ainda que haja renúncia por parte do credor, ainda que tácita, a regra inverte-se determinando a imputação do pagamento no capital e, depois nos juros, como se extrai da segunda parte do art. 354 do Código Civil.

Os juros remuneratórios oriundos do negócio jurídico de crédito decorrem do acordo de vontade das partes e são, portanto, convencionais, motivo pelo qual deixam de ser devidos se não houver previsão. Nada obsta, entretanto, que seja fixado por expressa previsão legal em negócios de outra natureza, como ocorre no mútuo a fins econômicos (art. 591 do Código Civil), no mandato (art. 677 do Código Civil) e na gestão de negócios (art. 869 do Código Civil).

A estes juros remuneratórios não se confundem os moratórios: aqueles são devidos desde a contratação até o vencimento da obrigação, enquanto estes apenas após o vencimento da obrigação.

O art. 407 do Código Civil, ao enunciar que os juros moratórios são devidos ainda que não se alegue prejuízo, lhes conferiu caráter punitivo. Decorrem, portanto, do inadimplemento do devedor no prazo avençado, e constituem penalidade ao descumprimento de obrigações de pagamento:

"Os interesses- juros ou outros - nada têm com os juros da mora. Aqueles são contraprestações, correspectivo 
do uso e fruição do capital que se emprestou. Esses supõem o não cumprimento da obrigação, a mora eficaz."69

Justamente por terem natureza punitiva, os juros moratórios são devidos por força de lei, a teor do que dispõe o art. 395 do Código Civil $^{70}$, diferentemente dos remuneratórios que são convencionais, exceto nos casos de títulos de crédito, cuja cláusula de juro é considerada não escrita (art. 890 do mesmo diploma legal ${ }^{71}$ ). Por este motivo, é que os juros moratórios compreendem-se no principal, dispensando a necessidade de sua formulação em pedido expresso, como determina o art. 293 do Código de Processo Civil ${ }^{72}$.

Esta penalidade fundamenta-se na proibição da alteração unilateral do contrato, previsto no art. 122 do Código Civil, impedindo que o credor se submeta ao arbítrio do devedor inadimplente. Mas estes juros decorrentes da mora rigorosamente também se tratam de frutos civis, uma vez que gerados em razão do rendimento do capital, todavia apresentam além, mais um elemento que o diferencia: a mora.

Para tanto, a fluência dos juros decorrentes da mora, diferente da fluência dos juros de interesse, presume não só a dívida como elemento fático da regra jurídica sobre juros, mas além a constituição do devedor em mora.

Cumpre observar que a mora não se confunde com inexecução, naquela ainda há a possibilidade e utilidade em receber o valor que era devido, permitindo que se pleiteie o pagamento acrescido de multa, correção monetária, e juros; enquanto nesta o adimplemento não é mais útil ou possível, caso em que serão pleiteados perdas e danos. Nos negócios financeiros o atraso no pagamento não se consubstancia em inexecução, o que motivará o cumprimento da obrigação com os demais encargos. Os juros moratórios, contudo, são considerados tanto no atraso do adimplemento, bem como nas perdas e danos.

\footnotetext{
${ }^{69}$ MIRANDA, Pontes de. Tratado de Direito Privado. Parte Especial. Tomo XLII. Ob. cit., p. 61.

70“Art. 395. Responde o devedor pelos prejuízos a que sua mora der causa, mais juros, atualização dos valores monetários segundo índices oficiais regularmente estabelecidos, e honorários de advogado."

71، Art. 890. Consideram-se não escritas no título a cláusula de juros, a proibitiva de endosso, a excludente de responsabilidade pelo pagamento ou por despesas, a que dispense a observância de termos e formalidade prescritas, e a que, além dos limites fixados em lei, exclua ou restrinja direitos e obrigações."

72،Art. 293. Os pedidos são interpretados restritivamente, compreendendo-se, entretanto, no principal os juros legais."
} 
Considera-se em mora o devedor que não efetuar o pagamento "no tempo, lugar e forma que a lei ou a convenção estabelecer", (art. 394 do Código Civil), desde que agido de maneira culposa (art. 393 c.c. 396 do referido diploma).

Por conseguinte, o devedor é constituído em mora, nas obrigações positivas ${ }^{73}$ e líquidas $^{74}$, quando de seu termo (se convencionado) ${ }^{75}$, ou quando da interpelação judicial ou extrajudicial (se não convencionado), nos termos do art. 397 do Código Civil.

Donde se colhe que, diferentemente dos juros remuneratórios que fluem desde a convenção, os requisitos necessários para a fluência de juros moratórios são a exigibilidade da prestação e a constituição do devedor em mora. Dispensa-se, portanto, a prova ou sequer a existência de prejuízo ao credor decorrente da mora do devedor, nos termos da primeira parte do art. 407 do Código Civil.

A mora, por sua vez, verifica-se quando presentes cumulativamente: i) inadimplemento ii) de forma culposa ${ }^{76}$; iii) o termo (mora ex re) ou a interpelação (mora ex persona).

O termo inicial, todavia, para a contagem dos juros moratórios, ao contrário do que se poderia presumir, comporta controvérsia, há quem sustente não decorrer do momento em que se constitui a mora, mas sim desde a citação inicial, à inteligência do art. 405 do referido diploma legal, que suprimiu a expressão "nas obrigações ilíquidas" prevista no art, 1.536, parágrafo $2^{\circ}$, do Código Civil de 1916.

Uma vez que o presente trabalho tem por objeto apenas as peculiaridades que se coadunam aos negócios jurídicos de crédito e, tendo em vista tratarem-se, pois, de obrigações líquidas, temos duas possíveis interpretações acerca do termo inicial para a contagem de juros moratórios no negócio financeiro: desde a constituição em mora do devedor ou desde a citação inicial.

A despeito do que reza o art. 405 do Código Civil, certo é que os juros moratórios possuem a natureza de penalidade pecuniária e, decorrem, por este motivo, da mora do

\footnotetext{
${ }^{73}$ Obrigações de dar e fazer.

${ }^{74}$ Existência certa e objeto determinado

75 “dies interpellat pro homine".

${ }^{76} \mathrm{~A}$ culpa há de ser do devedor. Casos cujo inadimplemento decorreu de caso fortuito ou força maior, de culpa exclusiva do credor, ou culpa exclusiva de terceiro, não há que se falar em mora.
} 
devedor. Todo o capítulo II do referido diploma legal dedica-se à conceituação e efeitos decorrentes desta mora. Para tanto, esclarece que o devedor responde pelos prejuízos a que sua mora der causa, mais juros e que, o termo ou interpelação constituirá em mora o devedor que inadimpliu ou adimpliu em condições diversas às pactuadas (art. 394 c.c. art. $395)$.

A interpretação da legislação não nos permitira concluir que, ainda que acordadas as partes acerca do vencimento das prestações devidas ou, além, quando interpelado o devedor nos termos do parágrafo único do art. 397 do Código Civil, os juros moratórios passariam a contar apenas e tão somente se provocado o Poder Jurisdicional, competente para determinar a citação inicial do processo e, dessa forma, fixar seu termo inicial.

Desta forma, apesar do art. 405 do Código Civil ter suprimido a expressão 'obrigações ilíquidas', os juros moratórios contam-se, nas obrigações positivas e líquidas, com prazo para cumprimento, a partir da constituição em mora do devedor (mora ex persona), nos termos do art. 394 e, nas obrigações positivas e líquidas, sem prazo determinado, a partir do momento da interpelação, notificação ou protesto (mora ex re), nos termos do art. 397, ambos do Código Civil. Neste sentido:

"Voto $n^{\circ}$ 983. Apelação cível $n^{\circ}$ 1.064.623-0/1. Comarca: São Paulo - Foro Central - 9a Vara Cível. os juros moratórios têm incidência a partir do vencimento de cada prestação, por se tratar de obrigação ex re, positiva e líquida, nos termos do artigo 397, caput, do Código Civil, e correspondente ao Diploma Civil anterior, no seu art.960.

Segundo Preleciona o professor Hamid Charaf Bdine Jr: "Se a obrigação é positiva e líquida e tem termo (prazo certo) para ser adimplida, verifica-se a mora na ocasião em que o cumprimento havia de ter sido implementado." (Código Civil Comentado, Coordenador Ministro Cezar Peluso. Barueri, São Paulo: lvlanole, 2007. p. 285)”

Os que entendem de maneira diversa, que os juros decorrentes da mora contar-seão a partir da citação inicial, restringem sua interpretação à análise do art. 405 do Código Civil, em face do antigo art, 1.536, do Código Civil de $1916 .^{77}$

\footnotetext{
77،"nada obstante a mora continue sendo considerada como a ausência do pagamento da obrigação positiva e liquida no seu temos (...) o art. 405 do Código Civil de 2002 não autoriza a cobrança de juros
} 
Ressalta-se, todavia, que a legislação especial pode exigir, para a comprovação da mora outros requisitos como o protesto de título ou envio por carta expedida pelo intermédio de Cartório, como ocorre nos contratos de alienação fiduciária, por força do art. $2^{\circ}$, parágrafo $2^{\circ}$ do Decreto-Lei 911/1969.

É o que se verifica também no tocante aos títulos de crédito que, a despeito de experimentarem juros a partir do vencimento, desde que convencionados nos casos permitidos em lei ${ }^{78}$, o único meio pelo qual se comprova a falta de pagamento é o protesto:

"até o seu vencimento, será exigível da letra apenas a importância nela mencionada, a não ser, segundo a Lei Uniforme, nas letras à vista e a certo tempo de vista em que tenha sido estipulada pelo sacador uma taxa de juros (...) o portador será prejudicado pelo não recebimento imediato da importância, que poderá ser por ele de pronto utilizada para outros negócios. Por tal razão, o seu capital deverá produzir juros (...) acontece, entretanto, que a falta ou recusa do pagamento são provadas mediante o protesto (...) de tal maneira, é o protesto o meio hábil para provar, também, que os devedores ficam sujeitos aos juros de mora, juros que se contam a partir do vencimento." 79

A matéria acerca da prescrição do crédito de juros não faz distinção entre juros remuneratórios e moratórios, convencionais ou legais e, ao teor do art. 206, § 3o, inciso III do Código Civil, determina que prescrevam em três anos as pretensões "para haver juros, dividendos ou quaisquer prestações acessórias, pagáveis, em períodos não maiores de um ano, com capitalização ou sem ela". Desta forma, faz-se necessário estarem presentes os requisitos referentes ao caráter de acessoriedade dos juros, bem como ao período de seu pagamento inferior a um ano.

Conseqüentemente, em se tratando de juros já agregados ao capital, como ocorre nos contratos de depósito em que os juros perdem seu caráter de acessoriedade depois de recebidos, ou de juros cujo período de pagamento exceda um ano, o prazo de prescrição a

moratórios antes da citação para a ação, mesmo na hipótese de juros moratórios convencionais (...) também neste caso, não obstante a interpelação judicial constitua o devedor em mora (...) os juros somente poderão ser contados após a citação inicial'. Ibid., p. 108-110.

78، "Art. 5०: Numa letra pagável à vista ou a um certo termo de vista, pode o sacador estipular que a sua importância vencerá juros. Em qualquer outra espécie de letra a estipulação de juros será considerada como não escrita." Decreto 57.663/1966 (Lei Uniforme).

${ }^{79}$ MARTINS, 1998, p. 210. 
ser considerado é o de 10 (dez) anos, conforme disposto no art. 205 do mesmo diploma. Sobre este assunto já se manifestou doutrina e jurisprudência, in verbis:

"Se os juros são capitalizáveis, em virtude de negócio jurídico, escapam ao art 178. §10, III No instante em que se tornam devidos e se insere no capital, há ação nata $e$ solução. A prescrição é da pretensão concernente ao capital. Não há qualquer pretensão a receber juros, estipulou-se exatamente que seriam simultâneos nascimento da dívida e solução. A automaticidade da contagem e capitalização exclui que se pense em descaso por parte do credor, ou em resguardar-se o devedor às conseqüências da demora em se lhes pedirem os juros ${ }^{\prime \prime} 80$

A relevância na distinção dos juros remuneratórios e moratórios decorre da diferenciação de suas disciplinas, uma vez que seus lineamentos repercutirão na aferição da obrigação de cunho patrimonial que o tomador do crédito haverá de cumprir em favor de seu credor.

${ }^{80}$ MIRANDA, Pontes de. Tratado de Direito Privado. Parte Geral. TomoVI. Ob. cit., p. 388. 


\subsection{JUROS COMPOSTOS E ANATOCISMO: UMA PROBLEMÁTICA DE CÁlCULO}

O Decreto-Lei 22.626, que rompia com a liberdade de fixação de taxa de juros, reproduziu em seu art. $4^{\circ}$, caput, os termos do art. 253 do Código Comercial, com vedação a cobrança de juros sobre juros, em períodos inferiores a um ano:

"Art. $4^{o}$. É proibido contar juros dos juros: esta proibição não compreende a acumulação de juros vencidos aos saldos líquidos em conta corrente de ano a ano."

A capitalização dos juros, ou comumente conhecido como anatocismo ('ana' = repetição; 'tokos' $=$ juro $)^{81}$, quer significar juro de juro. As controvérsias que se desenvolvem acerca do tema referem-se primordialmente a conceitos de matemática financeira, sem que nenhum autor tenha abordado de maneira satisfatória o assunto, analisando-o sob o enfoque do discurso do Direito.

A análise sob o aspecto da metodologia quantitativa apenas tem como objetivo fornecer instrumentos necessários para o estudo adequado dos dispositivos legais acerca do assunto, isto porque a ela incumbe oferecer o diagnóstico de como estes elementos se operacionalizam. Assim, o presente trabalho se respaldou em teorias de matemática financeira, amplamente divulgadas, cujas referências serão devidamente citadas ao longo do discurso.

Todavia, é no âmbito do ordenamento jurídico que a verdadeira problemática da questão se situa, pois a ele é conferida a condição de apresentar soluções para as relações que se compõem na ordem social. ${ }^{82}$

Os equívocos cometidos sobre o assunto dizem respeito a confusão que se faz entre juros compostos e anatocismo. Portanto, como questão preliminar é necessário delimitar o

\footnotetext{
${ }^{81}$ MENDONÇA, 1956, p. 91.

82،... ainda que a análise das questões inerentes à instrumentação monetária deva basear-se em explicações da teoria econômica, as soluções devem efetivar-se no âmbito da ordenação jurídica." CHIARA, José Tadeu de. A moeda e a ordem jurídica. Ob. cit., p. 46.
} 
conceito de juros simples e compostos. Serão considerados simples quando incidirem apenas sobre o valor principal, ou inicial, antes de somado qualquer valor, sem que incidam novos juros a cada período que se conte. Ou seja:

$$
\text { Juros simples }=K * i * n
$$

Onde:

K: Capital

i: taxa de juros por período

n: número de períodos

Por sua vez, serão considerados juros compostos aqueles somados ao capital em cada período para cálculo de novos juros nos períodos subseqüentes. Por este motivo, dizse juro capitalizado. Ou seja:

$$
\text { Juros compostos }=K *\left[(1+i)^{n}-1\right]
$$

Onde:

$\mathrm{K}$ : capital

i: taxa de juros por período

n: número de períodos

A título de ilustração, aplicando-se numa relação jurídica de crédito, cujo capital principal é de $\mathrm{R} \$ 1.000,00$, com taxa de juros pré fixada a $1 \%$ ao mês, a ser pago após o período de 12 meses, temos que: 
Se Juros Simples:

\begin{tabular}{|r|c|r|r|r|r|r|}
\hline & $\begin{array}{c}\text { Saldo } \\
\text { devedor ao } \\
\text { início do } \\
\text { período }\end{array}$ & $\begin{array}{c}\text { Juros } \\
\text { mensais 1\% }\end{array}$ & $\begin{array}{c}\text { Juros } \\
\text { acumulados }\end{array}$ & $\begin{array}{c}\text { Pagamento } \\
\text { de juros }\end{array}$ & $\begin{array}{c}\text { Pagamento } \\
\text { de principal }\end{array}$ & $\begin{array}{c}\text { Pagamento } \\
\text { total }\end{array}$ \\
\hline 1 & $\mathrm{R} \$ 1.000,00$ & $\mathrm{R} \$ 10,00$ & $\mathrm{R} \$ 10,00$ & $\mathrm{R} \$ 10,00$ & $\mathrm{R} \$ 1.000,00$ & $\mathrm{R} \$ 1.010,00$ \\
\hline 2 & $\mathrm{R} \$ 1.000,00$ & $\mathrm{R} \$ 10,00$ & $\mathrm{R} \$ 20,00$ & $\mathrm{R} \$ 20,00$ & $\mathrm{R} \$ 1.000,00$ & $\mathrm{R} \$ 1.020,00$ \\
\hline 3 & $\mathrm{R} \$ 1.000,00$ & $\mathrm{R} \$ 10,00$ & $\mathrm{R} \$ 30,00$ & $\mathrm{R} \$ 30,00$ & $\mathrm{R} \$ 1.000,00$ & $\mathrm{R} \$ 1.030,00$ \\
\hline 4 & $\mathrm{R} \$ 1.000,00$ & $\mathrm{R} \$ 10,00$ & $\mathrm{R} \$ 40,00$ & $\mathrm{R} \$ 40,00$ & $\mathrm{R} \$ 1.000,00$ & $\mathrm{R} \$ 1.040,00$ \\
\hline 5 & $\mathrm{R} \$ 1.000,00$ & $\mathrm{R} \$ 10,00$ & $\mathrm{R} \$ 50,00$ & $\mathrm{R} \$ 50,00$ & $\mathrm{R} \$ 1.000,00$ & $\mathrm{R} \$ 1.050,00$ \\
\hline 6 & $\mathrm{R} \$ 1.000,00$ & $\mathrm{R} \$ 10,00$ & $\mathrm{R} \$ 60,00$ & $\mathrm{R} \$ 60,00$ & $\mathrm{R} \$ 1.000,00$ & $\mathrm{R} \$ 1.060,00$ \\
\hline 7 & $\mathrm{R} \$ 1.000,00$ & $\mathrm{R} \$ 10,00$ & $\mathrm{R} \$ 70,00$ & $\mathrm{R} \$ 70,00$ & $\mathrm{R} \$ 1.000,00$ & $\mathrm{R} \$ 1.070,00$ \\
\hline 8 & $\mathrm{R} \$ 1.000,00$ & $\mathrm{R} \$ 10,00$ & $\mathrm{R} \$ 80,00$ & $\mathrm{R} \$ 80,00$ & $\mathrm{R} \$ 1.000,00$ & $\mathrm{R} \$ 1.080,00$ \\
\hline 9 & $\mathrm{R} \$ 1.000,00$ & $\mathrm{R} \$ 10,00$ & $\mathrm{R} \$ 90,00$ & $\mathrm{R} \$ 90,00$ & $\mathrm{R} \$ 1.000,00$ & $\mathrm{R} \$ 1.090,00$ \\
\hline 10 & $\mathrm{R} \$ 1.000,00$ & $\mathrm{R} \$ 10,00$ & $\mathrm{R} \$ 100,00$ & $\mathrm{R} \$ 100,00$ & $\mathrm{R} \$ 1.000,00$ & $\mathrm{R} \$ 1.100,00$ \\
\hline 11 & $\mathrm{R} \$ 1.000,00$ & $\mathrm{R} \$ 10,00$ & $\mathrm{R} \$ 110,00$ & $\mathrm{R} \$ 110,00$ & $\mathrm{R} \$ 1.000,00$ & $\mathrm{R} \$ 1.110,00$ \\
\hline 12 & $\mathrm{R} \$ 1.000,00$ & $\mathrm{R} \$ 10,00$ & $\mathrm{R} \$ 120,00$ & $\mathrm{R} \$ 120,00$ & $\mathrm{R} \$ 1.000,00$ & $\mathrm{R} \$ 1.120,00$ \\
\hline
\end{tabular}

Figura 1: Cálculo de juros simples.

Se Juros Compostos:

\begin{tabular}{|r|c|c|r|r|r|r|}
\hline Tempo & $\begin{array}{c}\text { Saldo } \\
\text { devedor ao } \\
\text { início do } \\
\text { período }\end{array}$ & $\begin{array}{c}\text { Juros } \\
\text { mensais 1\% }\end{array}$ & Juros acumulados & $\begin{array}{c}\text { Pagamento } \\
\text { de juros }\end{array}$ & $\begin{array}{c}\text { Pagamento } \\
\text { de principal }\end{array}$ & $\begin{array}{c}\text { Pagamento } \\
\text { total }\end{array}$ \\
\hline 1 & $\mathrm{R} \$ 1.000,00$ & $\mathrm{R} \$ 10,00$ & $\mathrm{R} \$ 10,00$ & $\mathrm{R} \$ 10,00$ & $\mathrm{R} \$ 1.000,00$ & $\mathrm{R} \$ 1.010,00$ \\
\hline 2 & $\mathrm{R} \$ 1.010,00$ & $\mathrm{R} \$ 10,10$ & $\mathrm{R} \$ 20,10$ & $\mathrm{R} \$ 20,10$ & $\mathrm{R} \$ 1.010,00$ & $\mathrm{R} \$ 1.030,10$ \\
\hline 3 & $\mathrm{R} \$ 1.030,10$ & $\mathrm{R} \$ 10,30$ & $\mathrm{R} \$ 30,40$ & $\mathrm{R} \$ 30,40$ & $\mathrm{R} \$ 1.030,10$ & $\mathrm{R} \$ 1.060,50$ \\
\hline 4 & $\mathrm{R} \$ 1.060,50$ & $\mathrm{R} \$ 10,61$ & $\mathrm{R} \$ 41,01$ & $\mathrm{R} \$ 41,01$ & $\mathrm{R} \$ 1.060,50$ & $\mathrm{R} \$ 1.101,51$ \\
\hline 5 & $\mathrm{R} \$ 1.101,51$ & $\mathrm{R} \$ 11,02$ & $\mathrm{R} \$ 52,02$ & $\mathrm{R} \$ 52,02$ & $\mathrm{R} \$ 1.101,51$ & $\mathrm{R} \$ 1.153,53$ \\
\hline 6 & $\mathrm{R} \$ 1.153,53$ & $\mathrm{R} \$ 11,54$ & $\mathrm{R} \$ 63,56$ & $\mathrm{R} \$ 63,56$ & $\mathrm{R} \$ 1.153,53$ & $\mathrm{R} \$ 1.217,08$ \\
\hline 7 & $\mathrm{R} \$ 1.217,08$ & $\mathrm{R} \$ 12,17$ & $\mathrm{R} \$ 75,73$ & $\mathrm{R} \$ 75,73$ & $\mathrm{R} \$ 1.217,08$ & $\mathrm{R} \$ 1.292,81$ \\
\hline 8 & $\mathrm{R} \$ 1.292,81$ & $\mathrm{R} \$ 12,93$ & $\mathrm{R} \$ 88,66$ & $\mathrm{R} \$ 88,66$ & $\mathrm{R} \$ 1.292,81$ & $\mathrm{R} \$ 1.381,47$ \\
\hline 9 & $\mathrm{R} \$ 1.381,47$ & $\mathrm{R} \$ 13,81$ & $\mathrm{R} \$ 102,47$ & $\mathrm{R} \$ 102,47$ & $\mathrm{R} \$ 1.381,47$ & $\mathrm{R} \$ 1.483,94$ \\
\hline 10 & $\mathrm{R} \$ 1.483,94$ & $\mathrm{R} \$ 14,84$ & $\mathrm{R} \$ 117,31$ & $\mathrm{R} \$ 117,31$ & $\mathrm{R} \$ 1.483,94$ & $\mathrm{R} \$ 1.601,25$ \\
\hline 11 & $\mathrm{R} \$ 1.601,25$ & $\mathrm{R} \$ 16,01$ & $\mathrm{R} \$ 133,32$ & $\mathrm{R} \$ 133,32$ & $\mathrm{R} \$ 1.601,25$ & $\mathrm{R} \$ 1.734,57$ \\
\hline 12 & $\mathrm{R} \$ 1.734,57$ & $\mathrm{R} \$ 17,35$ & $\mathrm{R} \$ 150,67$ & $\mathrm{R} \$ 150,67$ & $\mathrm{R} \$ 1.734,57$ & $\mathrm{R} \$ 1.885,24$ \\
\hline
\end{tabular}

Figura 2: Cálculo de juros compostos

Donde se extrai que, para este negócio, o devedor pagará ao final do empréstimo, no $12^{\circ}$ mês, a quantia de $\mathrm{R} \$ 1.120,00$, se calculado juros simples, ou a quantia de $\mathrm{R} \$$ $1.885,24$, se calculado juros compostos. 
As controvérsias surgem em se tratando de relações contratuais cuja liquidação se consolida em prestações iguais e sucessivas, que pressupõe o cálculo de juros compostos. Para apuração do valor de tais parcelas, decorrentes do empréstimo, é necessário se valer de um sistema de amortização, ou seja, dum processo de liquidação de uma dívida, mediante pagamentos periódicos e iguais, de modo que cada prestação corresponda à soma do capital e do pagamento dos juros, sendo estes calculados sobre o saldo devedor.

São inúmeros os sistemas de amortização desenvolvidos e utilizados por diferentes países: sistema de amortização constante, sistema de amortização misto, sistema americano de amortização, sistema de amortização variável, sistema alemão de amortização, mas é o sistema francês de amortização, conhecido também como Tabela Price, utilizado para o cálculo de amortização de empréstimos e financiamentos no Brasil, motivo pelo qual nos ateremos a ele.

O que se discute, na Tabela Price, diz respeito a forma de cálculo para se chegar no valor da prestação devida. O sistema de amortização francês é fundamentado nas prestações constantes e iguais, mas, principalmente, em valores de amortização progressivos, em que os juros variem na proporção do capital amortizado.

O sistema de amortização em testilha vale-se dum cálculo de juros compostos, conforme seu próprio autor Richard Price afirmou em sua obra "Tabela de Juros Compostos", tendo outros economistas demonstrado métodos que se valessem de juros simples ou progressão aritmética - fórmula de Gauss - sempre com a problemática de obter-se um resíduo final que comprometeria a igualdade das prestações sucessivas, e não remuneraria o capital na forma contratada. ${ }^{83}$

Aqueles que defendem a legalidade de sua utilização esclarecem que os juros capitalizados ocorrem apenas quando somados ao capital em cada período para cálculo de novos juros nos períodos subseqüentes, sendo que no sistema de amortização os juros apenas são devidos por conta do capital ainda não liquidado. ${ }^{84}$ Os que se posicionam em sentido contrário afirmam que juros sobre o saldo devedor ainda que sobre o capital não liquidado, implicam em capitalização de juros.

\footnotetext{
${ }^{83}$ VIEIRA SOBRINHO, 1989.

${ }^{84}$ D' AURIA, 1962.
} 
O procedimento de amortização dá-se calculando, nesta ordem: i) a prestação; ii) os juros sobre o saldo devedor no período anterior para cada período; iii) a amortização, para cada período a diferença entre a prestação e o juro; iv) o saldo devedor do período, com a diferença entre o saldo devedor do período anterior e a amortização. ${ }^{85}$

A prestação é o importe necessário para amortizar o capital nominal, considerando o saldo devedor ao início do período, à uma taxa de juros, para determinado período. Para que se chegue ao valor das prestações, no sistema de amortização francês, é necessário se valer da seguinte fórmula:

$$
\text { Parcela }=\text { capital } * \frac{(1+\text { taxa de juros })^{\text {tempo }} * \text { taxa de juros }}{(1+\text { taxa de juros })^{\text {tempo }}-1} 86
$$

Assim, temos que:

\begin{tabular}{|r|r|r|r|r|r|r|}
\hline Tempo & $\begin{array}{c}\text { Saldo } \\
\text { devedor ao } \\
\text { início do } \\
\text { período }\end{array}$ & $\begin{array}{c}\text { Juros } \\
\text { mensais 1\% }\end{array}$ & $\begin{array}{c}\text { Juros } \\
\text { acumulados }\end{array}$ & $\begin{array}{c}\text { Pagamento } \\
\text { de juros }\end{array}$ & $\begin{array}{c}\text { Pagamento } \\
\text { de principal }\end{array}$ & $\begin{array}{c}\text { Pagamento } \\
\text { total }\end{array}$ \\
\hline 1 & $\mathrm{R} \$ 1.000,00$ & $\mathrm{R} \$ 10,00$ & $\mathrm{R} \$ 10,00$ & $\mathrm{R} \$ 10,00$ & $\mathrm{R} \$ 78,85$ & $\mathrm{R} \$ 88,85$ \\
\hline 2 & $\mathrm{R} \$ 921,15$ & $\mathrm{R} \$ 9,21$ & $\mathrm{R} \$ 19,21$ & $\mathrm{R} \$ 9,21$ & $\mathrm{R} \$ 79,64$ & $\mathrm{R} \$ 88,85$ \\
\hline 3 & $\mathrm{R} \$ 841,51$ & $\mathrm{R} \$ 8,42$ & $\mathrm{R} \$ 27,63$ & $\mathrm{R} \$ 8,42$ & $\mathrm{R} \$ 80,43$ & $\mathrm{R} \$ 88,85$ \\
\hline 4 & $\mathrm{R} \$ 761,08$ & $\mathrm{R} \$ 7,61$ & $\mathrm{R} \$ 35,24$ & $\mathrm{R} \$ 7,61$ & $\mathrm{R} \$ 81,24$ & $\mathrm{R} \$ 88,85$ \\
\hline 5 & $\mathrm{R} \$ 679,84$ & $\mathrm{R} \$ 6,80$ & $\mathrm{R} \$ 42,04$ & $\mathrm{R} \$ 6,80$ & $\mathrm{R} \$ 82,05$ & $\mathrm{R} \$ 88,85$ \\
\hline 6 & $\mathrm{R} \$ 597,79$ & $\mathrm{R} \$ 5,98$ & $\mathrm{R} \$ 48,01$ & $\mathrm{R} \$ 5,98$ & $\mathrm{R} \$ 82,87$ & $\mathrm{R} \$ 88,85$ \\
\hline 7 & $\mathrm{R} \$ 514,91$ & $\mathrm{R} \$ 5,15$ & $\mathrm{R} \$ 53,16$ & $\mathrm{R} \$ 5,15$ & $\mathrm{R} \$ 83,70$ & $\mathrm{R} \$ 88,85$ \\
\hline 8 & $\mathrm{R} \$ 431,21$ & $\mathrm{R} \$ 4,31$ & $\mathrm{R} \$ 57,47$ & $\mathrm{R} \$ 4,31$ & $\mathrm{R} \$ 84,54$ & $\mathrm{R} \$ 88,85$ \\
\hline 9 & $\mathrm{R} \$ 346,67$ & $\mathrm{R} \$ 3,47$ & $\mathrm{R} \$ 60,94$ & $\mathrm{R} \$ 3,47$ & $\mathrm{R} \$ 85,38$ & $\mathrm{R} \$ 88,85$ \\
\hline 10 & $\mathrm{R} \$ 261,29$ & $\mathrm{R} \$ 2,61$ & $\mathrm{R} \$ 63,55$ & $\mathrm{R} \$ 2,61$ & $\mathrm{R} \$ 86,24$ & $\mathrm{R} \$ 88,85$ \\
\hline 11 & $\mathrm{R} \$ 175,05$ & $\mathrm{R} \$ 1,75$ & $\mathrm{R} \$ 65,31$ & $\mathrm{R} \$ 1,75$ & $\mathrm{R} \$ 87,10$ & $\mathrm{R} \$ 88,85$ \\
\hline 12 & $\mathrm{R} \$ 87,96$ & $\mathrm{R} \$ 0,88$ & $\mathrm{R} \$ 66,18$ & $\mathrm{R} \$ 0,88$ & $\mathrm{R} \$ 87,97$ & $\mathrm{R} \$ 88,85$ \\
\hline
\end{tabular}

Figura 3: Cálculo de amortização pelo sistema francês.

O valor da parcela, portanto, forma-se a partir da parcela do principal, à uma determinada taxa de juros sobre o importe que ainda não foi liquidado, para cada período.

\footnotetext{
${ }^{85}$ MATHIAS, 2008.

${ }^{86}$ Metodologia do financiamento com prestações fixas, disponível em www.bcb.gov.br, acessado em $19 / 09 / 2008$.
} 
O fator multiplicador 'tempo' sempre será = igual a 1, uma vez que cada novo período pressupõe a liquidação da prestação do período anterior.

Aplicando-se as fórmulas de juros simples e compostos, nas prestações iguais e sucessivas decorrentes do cálculo em conformidade à Tabela Price, teremos que:

Se juros simples:

\begin{tabular}{|r|r|r|}
\hline \multicolumn{1}{|c|}{ Tempo } & Juros Simples = (capital * taxa de juros * tempo) & Juros mensais \\
\hline 1 & $\mathrm{R} \$ 1.000,00 * 0,01 * 1$ & $\mathrm{R} \$ 10,00$ \\
\hline 2 & $\mathrm{R} \$ 921,15 * 0,01 * 1$ & $\mathrm{R} \$ 9,21$ \\
\hline 3 & $\mathrm{R} \$ 841,51 * 0,01 * 1$ & $\mathrm{R} \$ 8,42$ \\
\hline 4 & $\mathrm{R} \$ 761,08 * 0,01 * 1$ & $\mathrm{R} \$ 7,61$ \\
\hline 5 & $\mathrm{R} \$ 679,84 * 0,01 * 1$ & $\mathrm{R} \$ 6,80$ \\
\hline 6 & $\mathrm{R} \$ 597,79 * 0,01 * 1$ & $\mathrm{R} \$ 5,98$ \\
\hline 7 & $\mathrm{R} \$ 514,91 * 0,01 * 1$ & $\mathrm{R} \$ 5,15$ \\
\hline 8 & $\mathrm{R} \$ 431,21 * 0,01 * 1$ & $\mathrm{R} \$ 4,31$ \\
\hline 9 & $\mathrm{R} \$ 346,67 * 0,01 * 1$ & $\mathrm{R} \$ 3,47$ \\
\hline 10 & $\mathrm{R} \$ 261,29 * 0,01 * 1$ & $\mathrm{R} \$ 2,61$ \\
\hline 11 & $\mathrm{R} \$ 175,05 * 0,01 * 1$ & $\mathrm{R} \$ 1,75$ \\
\hline 12 & $\mathrm{R} \$ 87,96 * 0,01 * 1$ & $\mathrm{R} \$ 0,88$ \\
\hline
\end{tabular}

Figura 4: Aplicação de juros simples no cálculo de amortização francês.

Se juros compostos:

\begin{tabular}{|r|r|r|}
\hline \multicolumn{1}{|c|}{ Tempo } & Juros Compostos= capital [(1 + taxa de juros)^ tempo $-\mathbf{1}]$ & Juros mensais \\
\hline 1 & $\mathrm{R} \$ 1.000,00^{*}\left[(1+0,01)^{\wedge} 1-1\right]$ & $\mathrm{R} \$ 10,00$ \\
\hline 2 & $\mathrm{R} \$ 921,15^{*}\left[(1+0,01)^{\wedge} 1-1\right]$ & $\mathrm{R} \$ 9,21$ \\
\hline 3 & $\mathrm{R} \$ 841,51^{*}\left[(1+0,01)^{\wedge} 1-1\right]$ & $\mathrm{R} \$ 8,42$ \\
\hline 4 & $\mathrm{R} \$ 761,08^{*}\left[(1+0,01)^{\wedge} 1-1\right]$ & $\mathrm{R} \$ 7,61$ \\
\hline 5 & $\mathrm{R} \$ 679,84^{*}\left[(1+0,01)^{\wedge} 1-1\right]$ & $\mathrm{R} \$ 6,80$ \\
\hline 6 & $\mathrm{R} \$ 597,79^{*}\left[(1+0,01)^{\wedge} 1-1\right]$ & $\mathrm{R} \$ 5,98$ \\
\hline 7 & $\mathrm{R} \$ 514,91^{*}\left[(1+0,01)^{\wedge} 1-1\right]$ & $\mathrm{R} \$ 5,15$ \\
\hline 8 & $\mathrm{R} \$ 431,21^{*}\left[(1+0,01)^{\wedge} 1-1\right]$ & $\mathrm{R} \$ 4,31$ \\
\hline 9 & $\mathrm{R} \$ 346,67^{*}\left[(1+0,01)^{\wedge} 1-1\right]$ & $\mathrm{R} \$ 3,47$ \\
\hline 10 & $\mathrm{R} \$ 261,29^{*}\left[(1+0,01)^{\wedge} 1-1\right]$ & $\mathrm{R} \$ 2,61$ \\
\hline 11 & $\mathrm{R} \$ 175,05^{*}\left[(1+0,01)^{\wedge} 1-1\right]$ & $\mathrm{R} \$ 1,75$ \\
\hline 12 & $\mathrm{R} \$ 87,96^{*}\left[(1+0,01)^{\wedge} 1-1\right]$ & $\mathrm{R} \$ 0,88$ \\
\hline
\end{tabular}

Figura 5: Aplicação de juros compostos no cálculo de amortização francês.

Observe que os resultados dos juros mensais a cada período que se chega nas duas tabelas, sejam eles simples ou compostos, são exatamente os mesmo. A conseqüência que se colhe é que, a despeito da Tabela Price basear-se no cálculo de juros compostos, a utilização do cálculo para juros simples traduz o mesmo resultado numérico. 
Donde se colhem duas diferentes conseqüências: i) ainda que o sistema de amortização em análise esteja fundamentado no cálculo de juros sobre juros, é possível calculá-lo como juros simples; ii) para cada financiamento específico, é possível utilizar uma taxa de juros simples que equivalha a uma taxa de juros compostos. É o que evidencia a tabela abaixo:

\begin{tabular}{|c|c|c|c|c|c|c|c|c|}
\hline Tempo & \begin{tabular}{|l|} 
Saldo \\
devedor \\
no inicio \\
do \\
período \\
\end{tabular} & $\begin{array}{l}\text { Principal } \\
\text { no inicio } \\
\text { do } \\
\text { período }\end{array}$ & $\begin{array}{l}\text { Juros a } \\
\text { pagar no } \\
\text { inicio do } \\
\text { período } \\
\end{array}$ & $\begin{array}{l}\text { Juros } \\
\text { sobre } \\
\text { principal } \\
\text { a } 1 \% \\
\end{array}$ & \begin{tabular}{|l} 
Juros \\
sobre \\
juros a \\
$1 \%$ \\
\end{tabular} & $\begin{array}{l}\text { Pagament } \\
\text { o de juros } \\
\end{array}$ & $\begin{array}{l}\text { Pagamento } \\
\text { de } \\
\text { principal }\end{array}$ & $\begin{array}{l}\text { Pagamento } \\
\text { total }\end{array}$ \\
\hline 1 & $1.000,00$ & $1.000,00$ & 0,00 & 10,00 & 0,00 & 0,00 & 88,85 & 88,85 \\
\hline 2 & 921,15 & 911,15 & 10,00 & 9,11 & 0,10 & 0,00 & 88,85 & 88,85 \\
\hline 3 & 841,51 & 822,30 & 19,21 & 8,22 & 0,19 & 0,00 & 88,85 & 88,85 \\
\hline 4 & 761,08 & 733,45 & 27,63 & 7,33 & 0,28 & 0,00 & 88,85 & 88,85 \\
\hline 5 & 679,84 & 644,60 & 35,24 & 6,45 & 0,35 & 0,00 & 88,85 & 88,85 \\
\hline 6 & 597,79 & 555,75 & 42,04 & 5,56 & 0,42 & 0,00 & 88,85 & 88,85 \\
\hline 7 & 514,91 & 466,90 & 48,01 & 4,67 & 0,48 & 0,00 & 88,85 & 88,85 \\
\hline 8 & 431,21 & 378,05 & 53,16 & 3,78 & 0,53 & 0,00 & 88,85 & 88,85 \\
\hline 9 & 346,67 & 289,20 & 57,47 & 2,89 & 0,57 & 0,00 & 88,85 & 88,85 \\
\hline 10 & 261,29 & 200,35 & 60,94 & 2,00 & 0,61 & 0,00 & 88,85 & 88,85 \\
\hline 11 & 175,05 & 111,50 & 63,55 & 1,12 & 0,64 & 0,00 & 88,85 & 88,85 \\
\hline 12 & 87,96 & 22,65 & 65,31 & 0,23 & 0,65 & 66,20 & 22,65 & 88,85 \\
\hline 13 & $-0,02$ & 0,00 & $-0,02$ & 0,00 & 0,00 & 88,85 & 0,00 & 88,85 \\
\hline
\end{tabular}

\begin{tabular}{|l|r|c|}
\hline & \multicolumn{1}{|l|}{ Simples } & \multicolumn{1}{l|}{ Composto } \\
\hline Valor & $1.000,00$ & $1.000,00$ \\
\hline Taxa de juros mensal & $1,06 \%$ & $1,00 \%$ \\
\hline Juros & 126,83 & 126,83 \\
\hline Valor pago depois de 12 meses & $1.126,83$ & $1.126,83$ \\
\hline
\end{tabular}

Figura 6: Identificação de uma taxa de juros simples e uma taxa de juros compostos num exemplo dado.

Ainda que se considere que a proibição ao anatocismo abranja o cálculo de juros compostos (o que é equivocado, como veremos a seguir), resta evidenciado que a perspectiva econômica não nos fornece a solução adequada para a problemática levantada. Como forma de cálculo, já foi demonstrada que a aplicação de juros simples traduz o mesmo resultado que a de juros compostos e, por conseguinte, que em determinado financiamento, é possível se chegar a uma taxa de juros simples cujo resultado das parcelas 
periódicas seja igual ao de uma taxa de juros compostos. Assim, passa-se a analisar, sob o enfoque do ordenamento jurídico.

O entendimento acerca da aplicação do dispositivo legal que proibia a prática de cobrar juros de juros, contida no art. $4^{\circ}$ do Decreto-Lei $\mathrm{n}^{\circ} 22.626$, para negócios financeiros, não foi pacífico, principalmente em razão da Súmula n ${ }^{\circ} 596$ do Supremo Tribunal Federal ${ }^{87}$ que determinou que as disposições do referido diploma não se aplicariam a instituições que integram o Sistema Financeiro Nacional.

Questionamentos acerca do assunto suscitaram a provocação do Judiciário, que manifestou-se, em sede de Recurso Extraordinário $n^{\circ}$ 100.336/PE, entendendo que a referida Súmula não afastaria a aplicação da proibição do anatocismo às instituições financeiras, conforme voto do Relator, Min. Néri da Silveira:

"na conformidade dos julgados que informam a Súmula 121, a proibição do anatocismo constitui ius cogens. Da proibição posta no enunciado não estão excluídas as instituições financeiras. A Súmula 596 não afasta a aplicação da Súmula 121, na espécie".

A capitalização, pois, estaria permitida apenas no tocante às i) capitalizações anuais, conforme se extrai da parte final do referido dispositivo, bem como ii) às leis especiais, como nos financiamentos mediante cédulas de crédito rural, industrial e comercial, nos termos do art. $5^{\circ}$ do Decreto-Lei $167 / 67^{88}$ e Súmula 93 do STJ $^{89}$, nas Cédulas de Crédito Bancário, nos termos do art. 28, § $1^{\circ}$ da Lei 10.931/2.004 e iii) nos casos em que o Conselho Monetário Nacional (CMN) deliberasse no exercício da competência do art. $4^{\circ}$ da Lei 4.595/1964.

87، As disposições do Decreto 22626/1933 não se aplicam às taxas de juros e aos outros encargos cobrados nas operações realizadas por instituições publicas ou privadas, que integram o Sistema Financeiro Nacional."

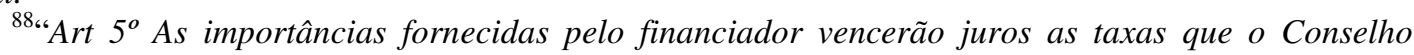
Monetário Nacional fixar e serão exigíveis em 30 de junho e 31 de dezembro ou no vencimento das prestações, se assim acordado entre as partes; no vencimento do título e na liquidação, por outra forma que vier a ser determinada por aquêle Conselho, podendo o financiador, nas datas previstas, capitalizar tais encargos na conta vinculada a operação.

Parágrafo único. Em caso de mora, a taxa de juros constante da cédula será elevável de 1\% (um por cento) ao ano."

${ }^{89}$ Súmula 93 do STJ: “A legislação sobre cédulas de crédito rural, comercial e industrial admite o pacto de capitalização de juros." 
Não há como socorrer-se na jurisprudência, visto não haver consenso acerca da matéria. Algumas decisões orientam-se no sentido de que a simples amortização calculada pela metodologia da Tabela Price não implica em anatocismo ${ }^{90}$, outras em sentido contrário $^{91} \mathrm{e}$, ainda, no sentido de que a verificação da prática de anatocismo dependeria de prova pericial e avaliação 'casu in $\operatorname{casu}^{\text {'92 }}$. Sinalizando acompanhar este último entendimento, o Superior Tribunal de Justiça, quando provocado a pronunciar-se sobre a matéria, fundamentou seu óbice na Súmula 07 que determina: "a pretensão de simples reexame de prova não enseja recurso especial".

Disse-se, na ocasião, que o equívoco diz respeito ao cálculo de juros compostos implicar anatocismo, motivo pelo qual o conceito de juros compostos e a metodologia de amortização da Tabela Price foram elucidados quantitativamente, sem oferecer resposta satisfatória. Para tanto, a conceituação dos diferentes institutos, sob seu aspecto qualitativo, torna-se imprescindível para dirimir a questão. ${ }^{93}$

Ensina José Tadeu De Chiara ${ }^{94}$ que, no tocante aos juros, duas problemáticas se colocam: a forma de cálculo e a forma de cobrança. Quando o dispositivo legal veda contar “juros de juros” está tratando a forma de cobrança e não de cálculo, senão vejamos.

Conforme já exposto, os juros têm natureza jurídica de fruto civil, são, pois, créditos acessórios, que expressam o preço da recompensa pela renúncia da liquidez. Esta renúncia representa o resigno do exercício de direitos de cunho patrimonial que o titular de instrumento monetário dispõe.

Assim, uma unidade de tempo mensal, poderá ser fracionada em trinta porções de um dia cada, desde que devidamente representada, diariamente, a renúncia da liquidez pelo titular do crédito acessório de juros. Para tanto, faz-se necessário calcular o preço desta renúncia, a cada dia, a uma taxa de juros, remunerando assim o capital emprestado.

\footnotetext{
${ }^{90}$ São Paulo, Tribunal de Justiça, Ap. 1248480700, Ap. 3173174800, Ap. 7168980200.

${ }^{91}$ São Paulo, Tribunal de Justiça, Ap. 7236587600, EI 975320601, Ap. 7000322800.

${ }^{92}$ São Paulo, Tribunal de Justiça, Ap. 1190489100 , Ap. 7301655200.

93“Dizem-se simples os juros que não produzem juros; juros compostos os que fluem dos juros. Se se disse 'com os juros compostos de seis por cento', entende-se que se estipulou que o principal daria juros de seis por cento e sobre esses se contariam os juros de seis por cento ao ano (= com capitalização anual." MIRANDA, Pontes de. Tratado de Direito Privado. Parte Especial. Tomo XXIV. Ob. cit., p. 32.

${ }^{94}$ CHIARA, José Tadeu de. A moeda e a ordem jurídica. Ob. cit., p. 135.
} 
Se considerada a fração individual da renúncia em se exercitar direitos a cada dia, temos que o resultado desta aplicação de taxa de juros nominal será equivalente a soma de cada uma destas frações do período considerado de um mês.

Todavia, esta taxa de juros nominal não leva em consideração o crédito acessório de juros, apenas o principal. Ocorre que este acessório, não auferido, também expressa um conteúdo de direito não exercitado, que deverá ser levado em conta na forma de cálculo, sob pena de confrontar o equilíbrio econômico-financeiro do contrato.

Incumbe a taxa de juros compostos considerar na forma de cálculo estes créditos acessórios cuja renúncia foi feita, bem como o crédito principal. Se a cada dia recebido e, não exercitado, uma nova renúncia é considerada, temos que o resultado da aplicação de juros compostos será equivalente a exponenciação de cada uma destas frações do período considerado de um mês. ${ }^{95}$

Donde se extrai que: i) o juro simples não leva em consideração todo o conteúdo de direito não exercitado, pois incide apenas sobre o principal, enquanto que o juro composto incide sobre principal e acessório; ii) o juro simples representa-se pela soma de taxa nominal aplicada a cada período, enquanto o juro composto pela exponenciação de taxa aplicada a cada período.

O que veda a lei é que este cálculo ao final do período considerado de um mês integre-se ao capital principal, para a cobrança de nova taxa de juros em período subseqüente. Quer-se dizer com isso que a lei proíbe submeter o crédito acessório ao regime de cobrança do crédito principal, referindo-se, portanto, a forma de cobrança e não de cálculo.

Ora, juros simples ou compostos são conceitos que se coadunam a unidade de medida, de maneira que, a despeito de suas diferentes formas de cálculo, quando aplicadas no sistema de amortização francês, geram o mesmo resultado. É por este motivo que se tornam descabidos argumentos no sentido de que a matemática financeira admite apenas duas formas de aplicação de juros: simples e compostos, sendo que este implicaria em anatocismo.

${ }^{95}$ CHIARA, José Tadeu de. A moeda e a ordem jurídica. Ob. cit., p. 135. 
O ordenamento jurídico apenas vedou a forma de cobrança - contar juros de juros, e não a forma de cálculo - juros compostos, ou seja, proibiu a prática de juros mensais capitalizados e não de juros compostos. A vedação ao anatocismo refere-se à proibição ao término do cálculo do juro no período de um mês se incorporar este valor ao principal, não se refere, entretanto, a forma de cálculo simples ou composta, que pode ser cobrada naturalmente.

Interpretação em sentido contrário seria descabida, uma vez que matéria de cálculo é estranha ao Direito. Ora, o ordenamento jurídico, ao estipular que na amortização de débitos vencidos imputa-se o pagamento primeiro nos encargos de mora, nos juros remuneratórios e no principal (arts. 352 a 355 do Código Civil), não está regulamentando forma de cálculo, mas sim forma de cobrança.

Por este motivo, os juros apenas capitalizam-se quando não satisfeito o crédito acessório anterior no período de um mês e, desde que integrem o principal para fundamentar o cálculo de taxa de juros subseqüente. $\mathrm{O}$ anatocismo, portanto, apenas verifica-se quando contado juros de juros, ou seja, em se tratando de negócio jurídico a liquidar-se em prestações iguais e sucessivas, quando os juros da parcela anterior não liquidada integrar o principal para cobrança de juros da parcela subseqüente, desde que em período inferior a um ano.

Forma de cálculo e forma de cobrança não se trata de mera questão semântica. Cobrança é o exercício do núcleo do direito subjetivo, enquanto que cálculo diz respeito a metodologia quantitativa e, por isso mesmo, conforme utilização de técnicas diversas, é possível que se chegue num mesmo resultado. A noção de cálculo, por este motivo, não se coaduna ao preceito normativo, que exige, em razão de sua natureza, a previsão de hipótese e conseqüência.

Enquanto a metodologia quantitativa descreve, o direito prescreve. Nesta oportunidade, vale relembrar os ensinamentos de Goffredo Telles Jr:

"Cada norma jurídica é relativa à circunstância para a qual ela é destinada. Verificada a circunstância, o movimento exigível ou o movimento proibido é o que a norma enuncia. Por este motivo, toda norma jurídica tem estrutura hipotética. $O$ que ela preceitua somente vigora na 
hipótese de se verificar a circunstância para a qual a mesma foi enunciada. Essencialmente, a estrutura da norma jurídica pode sempre ser reduzida ao esquema: Se A é, B deve ser. (...)seja qual for sua forma, a norma jurídica é sempre o enunciado de uma ação humana, que pode ser exigida, ou que é proibida, uma vez verificada a circunstância ou hipótese para a qual a norma foi elaborada." 96

Norberto Bobbio destacou entre os critérios comumente utilizados para a diferenciação das proposições prescritivas jurídicas, o referente a seu conteúdo, qual seja, de que as normas jurídicas restariam por regular sempre relações intersubjetivas. Nesta explicação, elucidou que não trataria de regular a relação entre uma pessoa e uma coisa, nem entre uma pessoa e si mesma, mas sim entre uma pessoa e outra pessoa. ${ }^{97}$

Ademais, adicionou a este o critério de violação, enunciando que a norma jurídica é aquela cuja execução é garantida por uma sanção externa e institucionalizada (previsão da sanção, bem como de sua exata medida e do encarregado a aplicá-la), explicou ainda que a possibilidade da transgressão de uma norma jurídica é o que a distingue de uma lei científica. Considerando que ambas estabelecem uma relação de condição e conseqüência, se a consequiência no segundo caso não se verifica, a lei científica deixa de ser verdadeira, mas se, no entanto, não se verifica no primeiro caso, a norma jurídica continua a ser válida:

"Em um sistema cientifico, no caso em que os fatos desmintam uma lei, nos orientamos no sentido da modificação da lei; em um sistema normativo, no caso em que a ação deveria ocorrer não ocorre, nos orientamos sobretudo no sentido de modificar a ação e salvar a norma. No primeiro caso, o contraste é sanado agindo sobre a lei e, por conseguinte, sobre o sistema; no segundo caso, agindo sobre a ação não conforme e, assim, procurando fazer com que a ação não ocorra ou, pelo menos, tentando neutralizar as suas conseqüências." "98

A forma de cálculo, ou mais precisamente, o conceito de juros compostos sobre o qual recai o presente estudo, não poderia ser confundida com a norma jurídica que se

\footnotetext{
${ }^{96}$ TELLES JR., 19? p. 259 -260.

${ }^{97}$ BOBBIO, 2001.

${ }^{98}$ Ibid., p. 153.
} 
discute. O cálculo não apresenta a estrutura de hipótese de incidência e conseqüência, própria do sistema jurídico, cuja expressão formular-se-ia na proposição: 'se A é, deve ser $B^{\prime}$, não prescreve, mas sim descreve, bem como não regulamenta relações intersubjetivas, quanto menos cuja violação implicaria numa sanção externa institucionalizada. Indo mais além, juros compostos é elemento que diz respeito a dados de quantidade, naturalmente estáticos, enquanto que anatocismo diz respeito a dados de qualidade, naturalmente dinâmicos. $^{99}$

Por todo o exposto, resta evidenciado de maneira cristalina que o dispositivo legal em comento, qual seja, art. $4^{\circ}$ do Decreto-Lei $n^{\circ} 22.626 / 33$, ao enunciar a vedação de contar juros de juros, não proibiu a prática de juros compostos, inerente a forma de cálculo, e estranha a realidade do Direito. Diferentemente, proibiu a forma de cobrança, ou seja, que o cálculo a uma taxa de juros ao final do período considerado de um mês integre-se ao capital principal, para a cobrança de nova taxa de juros em período subseqüente.

Na prática, a utilização do cálculo de juros compostos em qualquer sistema de amortização, não implica em ilicitude. A ilicitude só decorre se, findo o período de um mês, os créditos acessórios integrarem o crédito principal, compondo assim base de cálculo para novo crédito acessório.

Ao ano de 2000, contudo, esta questão se resolveria no âmbito do ordenamento jurídico, visto que seria admitida a capitalização de juros em período inferior a um ano, em operações realizadas por instituições integrantes do Sistema Financeiro Nacional, por força da Medida Provisória 1.963-17, de 30.3.00, reeditada várias vezes e hoje consolidada na Medida Provisória 2.170, de 23.8.01, cuja aplicabilidade foi sacramentada pelo Superior Tribunal de Justiça:

"Aos contratos celebrados após a vigência da MP $n$. 1963-17/2000, reeditada sob o $n$. 2.170-36, possível a capitalização de juros em períodos inferiores a um ano. Agravo regimental acolhido em parte, para conhecer do

\footnotetext{
99"Por essas razões, a observação, a experimentação, a comparação, a utilização dos métodos indutivo, dedutivo e de inferência, aplicam-se dominantemente sobre dados de qualidade, nas Ciências Culturais, e não tanto sobre elementos de quantidade quanto nas Ciências Físicas e Biológicas." VIDIGAL, 1973 , p. 120.
} 
recurso especial no que tange à capitalização dos juros $e$ permiti-la na forma pactuada."100

Hodiernamente, a autorização da prática do anatocismo em negócio financeiro no período inferior a um ano, é objeto de discussão em sede de Ação Direta de Inconstitucionalidade, que tramita sob o $\mathrm{n}^{\circ}$ ADIn 2316/DF, e respalda-se nos principais fundamentos de inconstitucionalidade formal e material.

No que se refere ao primeiro aspecto, foram questionados os pressupostos de relevância e urgência para a edição da Medida Provisória, alegando que a matéria haveria de ser disciplinada em sede de lei complementar, nos termos do art. 192 da Magna Carta e, ainda, a maneira "sorrateira" pela qual foi inserido o dispositivo em questão, visto que a Medida Provisória competiria tratar apenas da administração dos recursos de caixa do Tesouro Nacional.

Quanto ao segundo aspecto, informou que a capitalização de juros implicaria em onerosidade excessiva para o tomador de empréstimo e os efeitos desta prática seriam incompreensíveis pelo homem médio. Ademais, discutiu que cobrar juros de juros seria cobrar aquilo que não se emprestou, o que o ordenamento jurídico vedaria, em tese.

A propósito do debate acerca da suposta inconstitucionalidade formal, não merece prosperar o argumento de que a matéria padece de relevância e urgência. Ora, exaustivamente já foi elucidado que os requisitos de urgência e relevância para a adoção das medidas provisórias se coadunam a natureza discricionária dos atos praticada pelos agentes públicos. Para tanto, no conjunto de requisitos de competência, finalidade, forma motivo e objeto, é a estes dois que falta previsão legal e permite ao agente - no caso o Chefe do Poder Executivo - praticá-lo com liberdade de escolha de seu conteúdo, conforme sua análise de conveniência e oportunidade.

Outrossim, o controle de constitucionalidade não é cabível quanto a este juízo de conveniência e oportunidade, pois se assim o fosse, restaria por substituir o juízo subjetivo do administrador público pelo pronunciamento do Judiciário, sem fundamento legal. O que se permite, entretanto, é que sejam revistos os atos discricionários nos limites materiais conferidos por lei, quais sejam, os pertinentes aos requisitos de competência, finalidade e

${ }^{100}$ Superior Tribunal de Justiça, AgRg no Resp 609257/RS, AgRg no Ag 562712/RS. 
forma, para que assim se verifique se houve excesso de poder, desvio de finalidade ou omissão na administração. É neste sentido que se extrai a lição da doutrina e jurisprudência, in verbis:

"Não se pode, pois, em tal elemento, substituir o critério da Administração pelo pronunciamento do Judiciário, porque isto importaria revisão do mérito administrativo, por uma simples mudança de juízo subjetivo." 101

"Os conceitos de relevância e de urgência a que se refere o art. 62 da Constituição, como pressupostos para a edição de Medidas Provisórias, decorrem, em princípio, do Juízo discricionário de oportunidade e valor do Presidente da República, mas, admite o controle judiciário quanto ao excesso do poder de legislar, o que, no caso, não se evidencia de pronto.",102

No mais, não há como admitir o argumento que a Medida Provisória em comento competiria apenas legislar sobre a administração dos recursos de caixa do Tesouro Nacional e, conseqüentemente, qualquer outro assunto estranho a esta matéria restaria prejudicado. Caso contrário, estaríamos confrontando a noção do Direito como sistema, que pressupõe, necessariamente, como elemento fundamental de sua estrutura a unidade. Savigny $^{103}$ já havia feito esta ressalva ao conceituar o sistema de Direito como a concatenação interior que liga todos os institutos jurídicos e as regras de Direito numa grande unidade.

A unidade sobre a qual repousa o sistema de Direito não se confunde com as normas positivadas. Indo mais além, nos ensinamentos de Eros Roberto Grau ${ }^{104}$, o Direito compõe-se não apenas de direito posto, mas também de direito pressuposto, a norma faz-se jurídica no momento em que as massas das consciências individuais chegam a compreensão de que a sanção material desta norma pode ser socialmente organizada. Teremos aqui que as normas jurídicas abrangem tanto regras positivadas, quanto princípios gerais, podendo estes, estarem ou não positivados no ordenamento jurídico. São eles, pois, que consubstanciam a unidade do direito (vide capítulo 3.5).

\footnotetext{
${ }^{101}$ MEIRELLES, 2003, p. 150.

${ }^{102}$ Supremo Tribunal Federal, ADIn 162-1/DF.

${ }^{103}$ SAVIGNY, 1979.

${ }^{104}$ GRAU, 2001.
} 
A unidade, portanto, não se restringe as regras jurídicas positivadas, muito menos se limita a valores singulares de isolamento aparente - como propõe o argumento em análise - sob pena de se justificar a adequação valorativa e a unidade do Direito num sistema lógico formal. Vale relembrar as lições de Canaris:

"No que respeita, em primeiro lugar, à ausência de contradições, é seguro, como geralmente se reconhece, que se deve negar uma contradição entre duas normas, em todas as circunstâncias (...) contudo, isso só funciona para verdadeiras contradições de normas, enquanto que as contradições de valores e de princípios não se deixam evitar sem exceções (...) o sistema, devendo exprimir a unidade aglutinadora das normas singulares não pode, pelo que lhe toca, consistir apenas em normas; antes deve apoiar-se nos valores que existam por detrás delas ou que nelas estejam compreendidos. (...) A realização da segunda característica, da plenitude, é, no entanto, totalmente impossível. (...) o postulado da plenitude iria exigir, não só que as normas fundamentais de uma lei, com as suas exceções, mas também todos os preceitos (escritos e não escritos!) devessem ser elevados à categoria de axiomas. "105

Aí está o fundamento que revela o equívoco do argumento de que o dispositivo em comento deve guardar pertinência à matéria de administração dos recursos de caixa do Tesouro Nacional tratada pela Medida Provisória. Na verdade, o que deve observar referese à adequação valorativa e os princípios gerais que conservem a unidade e ordenação do direito.

Sobre a inconstitucionalidade material, as considerações discorridas até o presente momento são suficientes para rebater o raciocínio que cobrar juros de juros seria cobrar aquilo que não se emprestou, do que importa apenas ratificar que a equivalência entre situações de liquidez há de ser resguardada enquanto perdurar o negócio, sem que se deixe de levar em conta todos os elementos necessários para assegurá-la.

Finalmente, a constatação acerca da capitalização de juros implicar em onerosidade excessiva, vedada pelo nosso ordenamento jurídico, nos termos do arts. 478 a 480 do Código Civil, também não merece prosperar.

${ }^{105}$ CANARIS, 1989, p. 41-42. 
Isto porque, em sendo o juro elemento que decorre da comparação de diferentes situações de liquidez, é matéria que opera no plano da medida do equivalente e, portanto, se perfaz sob os critérios do equilíbrio econômico-financeiro e da vedação ao enriquecimento sem causa e, não sob o critério da onerosidade excessiva, que opera no plano da alteração das circunstâncias sobre as quais as partes fundaram sua decisão de contratar e, portanto, sobre a base no plano da base objetiva do negócio ${ }^{106}$ (vide capítulo 3.1.).

${ }^{106}$ Os requisitos necessários para que se verifique a onerosidade excessiva ratificam este entendimento, quais sejam: i) vigência de um contrato de execução diferida, oneroso e comutativo; ii) alteração de circunstâncias fáticas relevantes, considerando o momento da celebração do contrato e o momento do cumprimento de pelo menos uma das prestações; iii) a constatação de desproporção entre prestação e contraprestação; iv) nexo de causalidade entre (ii) e (iii); v) imprevisibilidade do evento que causou a alteração das circunstâncias e o excesso de uma das partes. MOURA, Cristiane Angélica. Conteúdo dos requisitos para resolução dos contratos por onerosidade excessiva da prestação no novo Código Civil. Ob. cit. p. 31-21. 


\subsection{COMISSÃO DE PERMANÊNCIA}

Disse-se que os juros remuneratórios são aqueles que fluem desde a contratação até o vencimento e, que os juros moratórios, aqueles que fluem após o vencimento. Quanto aquele foi verificado seu caráter compensatório pela renúncia da liquidez, quanto a estes, seu caráter de penalidade, diante da ausência de necessidade em se alegar prejuízo para sua cobrança, nos termos do art. 407 do Código Civil.

Outrossim, foi constatado que o regime dos juros remuneratórios está disciplinado em lei especial, enquanto que o regime jurídico dos juros que fluem após o vencimento da obrigação está disciplinado no Código Civil, pelo regime da mora, uma vez que a Lei ${ }^{\circ}$ 4.595/64 ao atribuir ao Conselho Monetário a competência para regular taxa de juros o fez apenas no tocante ao remuneratório, silenciando quanto ao moratório.

Ao lado dos juros remuneratórios e dos moratórios, com o advento da Resolução $\mathrm{n}^{\circ} 15$ de 28.01.1966 do Banco Central do Brasil (Bacen), reeditada e consolidada no Manual de Normas e Instruções - MNI 01-02-03 ${ }^{107}$, surge uma nova figura denominada 'comissão de permanência':

"Os bancos múltiplos, os bancos comerciais, os bancos de desenvolvimento, os bancos de investimento, as caixas econômicas, as cooperativas de crédito, as sociedades de crédito, financiamento e investimento $e$ as sociedades de arrendamento mercantil podem cobrar de seus devedores por dia de atraso no pagamento ou na liquidação de seus débitos, além de juros de mora na forma da legislação em vigor, comissão de permanência calculada as mesmas taxas pactuadas no contrato original ou a taxa de mercado do dia do pagamento, não sendo permitida a cobrança de quaisquer outras quantias compensatórias pelo atraso no pagamento dos débitos vencidos.

Nas operações não enquadradas no âmbito do Sistema Financeiro da Habitação (SFH), as entidades do Sistema Brasileiro de Poupança e Empréstimo (SBPE) definidas no item 2-5-2-2 podem cobrar de seus devedores,

${ }^{107}$ Atualmente, a comissão de permanência é disciplinada em três Resoluções do Banco Central do Brasil: Resolução 1.129 de 15.05.1986; Regulamento anexo à Resolução 1.980 de 30.04.1993 e Regulamento anexo à Resolução 3.005 de 30.07.2002. 
por dia de atraso no pagamento ou na liquidação de seus débitos, os encargos previstos no item anterior."

Uma primeira análise do texto normativo nos fornece a compreensão de três vertentes acerca da comissão de permanência: quem poderá cobrar, quando poderá cobrar e quanto poderá cobrar. Em primeira ordem de observação, tem legitimidade para a cobrança qualquer instituição financeira, desde que prevista na Resolução 1.129/86, com exclusão, portanto, de todas as instituições não financeiras, ainda que submetidas à fiscalização do Banco Central, bem como das instituições financeiras não previstas no texto normativo, como as sociedades corretoras e distribuidoras de títulos e valores mobiliárias.

Em sendo legítimas apenas as instituições que compõe o Sistema Financeiro Nacional, a cobrança da comissão de permanência justifica-se apenas em operações de crédito, ou seja, quando previstas em contratos ou títulos de crédito que consubstanciam o negócio financeiro. Não se justifica, portanto, em negócios mercantis ou em contratos de mútuo.

No tocante aos financiamentos imobiliários, temos duas naturezas de negócio: as que se enquadram e, se submetem a condições especiais de contratação, no regime previsto pela Lei $\mathrm{n}^{\circ} 4.380 / 64$, e as que não se enquadram no Sistema Financeiro de Habitação, submetendo-se a taxas de mercado. Para aquelas, a cobrança da comissão de permanência é vedada.

Quanto a sua exigibilidade, a redação da Resolução 1.129/86, ao enunciar que 'os bancos... podem cobrar', evidencia o caráter dispositivo da norma pois apenas conferiu às instituições financeiras a faculdade de realizar a cobrança da comissão de permanência. Por conseguinte, apenas será devida quando houver previsão expressa no contrato. Acompanhando este entendimento, já decidiu o Tribunal de Justiça de São Paulo: "É admitida a incidência da comissão de permanência, após o vencimento do débito, desde que pactuada." 108

Não haveria como se concluir de maneira diversa, uma vez que a comissão de permanência, como será analisado, tem natureza de juros remuneratórios, portanto é 
obrigação de fonte convencional, inexistindo previsão legal que lhe confira caráter punitivo em decorrência do inadimplemento contratual, ao lado dos encargos moratórios.

É necessário ainda que o débito seja devido e vencido para a cobrança da comissão, isto porque o texto normativo exige que o devedor esteja em atraso no pagamento. Note-se, porém, que o dispositivo legal apenas fala em 'por dia de atraso', donde se conclui que o simples atraso é suficiente para a exigência da comissão de permanência, não sendo necessária a constituição do devedor em mora, nos termos do art. 397 do Código Civil.

No tocante ao quantum devido, diz a Resolução que a comissão de permanência é calculada "por dia de atraso no pagamento ou na liquidação de seus débitos (...) às mesmas taxas pactuadas no contrato original ou a taxa de mercado do dia do pagamento”. Ela incide, portanto, sobre o saldo devedor à data do cálculo, com todos seus encargos, à taxa pactuada no contrato original ou de mercado do dia do pagamento.

Quando aplicada a taxa pactuada no contrato original, continuam contando os juros remuneratórios convencionados após o vencimento da obrigação, sem que haja maiores dificuldades. Entretanto, a aplicação da taxa de mercado do dia do pagamento incitou inúmeras manifestações no sentido desta cláusula contratual ser potestativa, sob o fundamento de que uma das partes unilateralmente poderia alterar as condições do negócio, o que é vedado pelo Código Civil (art. 122).

Ocorre que o que o Codex pró́be diz respeito à condição que sujeita o efeito do negócio jurídico ao puro arbítrio de uma das partes, sendo certo que a previsão da cobrança da comissão de permanência, em conjunto com o devedor, sob critérios objetivos que definam a forma com que a taxa será composta, ainda que sem previsão de taxa especifica, basta para afastar a ilicitude de sua cobrança. Quer-se dizer com isso que é permitido contratar cláusulas que submetam prestações a índices pós-fixados ou taxas flutuantes, ainda que divulgadas e apuradas por terceiros não integrantes do contrato, sem que se colha ilegalidade:

"a própria Resolução $n^{\circ} 1.129 / 86$, do Banco Central do Brasil, no item I, estabelece que a comissão de permanência será calculada as mesmas taxas pactuadas no contrato original ou à taxa de mercado do dia do pagamento. Não há aí potestatividade, já que as taxas de 
mercado não são fixadas pelo credor, mas, sim, definidas pelo próprio mercado ante as oscilações econômicofinanceiras, estas fiscalizadas pelo Governo que, como sói acontecer, intervém para sanar distorções indesejáveis." 109

Este entendimento foi consolidado pela Súmula 294 do Superior Tribunal de Justiça, que diz: "Não é potestativa a cláusula contratual que prevê a comissão de permanência, calculada pela taxa média de mercado apurada pelo Banco Central do Brasil, limitada à taxa do contrato."

Todavia, a comissão de permanência fixada à taxa de mercado colhe a inevitável conseqüência de inviabilizar a sua cobrança pela via executiva, em razão de contaminar a liquidez do título que dela dispõe.

Certo é que para a execução por quantia certa, é necessário que o crédito fundamente-se em título líquido, certo e exigível (art. 586 do Código de Processo Civil). Esta liquidez diz respeito a exata determinação do valor a ser entregue ao credor, ainda que o conhecimento deste valor decorra dum simples cálculo aritmético.

A apuração da taxa média praticada no mercado, nos termos da Resolução n 1.129 do Bacen, exige um cálculo com maior complexidade que a simples operação aritmética, porque resulta da composição de diferentes situações de liquidez, acrescidos de diferenciais de risco, garantias e atribuições de cada caso, variável, portanto, dia a dia, banco a banco.

Contudo, diferentemente do que sugerem alguns, a iliquidez da comissão de permanência não prejudica toda a execução, procedimento pelo qual poderá ser cobrado os demais encargos contratuais: "Por não de natureza cambial e por ter sido ajustada em pacto adjeto à cártula, a comissão de permanência não pode ser cobrada por via executiva, onde os acréscimos devem ser somente de juros legais e de correção monetária

\footnotetext{
${ }^{109}$ Superior Tribunal de Justiça, REsp 271.214 - RS (2000/0079249-7), voto do Min. Carlos Alberto
} Menezes. 
pelos índices oficiais, que poderão ser calculados pelo contador judicial, sem o monitoramento do credor." 110

Quando os tribunais repudiam a comissão de permanência, o fazem sob o fundamento de que esta teria um caráter tríplice, abrangendo juros remuneratórios, juros moratórios e correção monetária, de tal forma que a sua acumulação com demais encargos configuraria bis in idem, pois o motivo que geraria a possibilidade de sua cobrança já estaria presente em outros institutos: na recompensa pela renúncia da liquidez, quando juros remuneratórios, no inadimplemento, quando juros moratórios e, na perda do poder aquisitivo da moeda, quando correção monetária. ${ }^{111}$

A doutrina também não é unânime ao se manifestar sobre o assunto e, muitas vezes, apenas como forma de criticar a cobrança considerada excessiva dos encargos decorrentes do negócio financeiro, atribui à comissão de permanência o caráter de cláusula penal moratória, distorcendo sua função precípua de remuneração do capital. ${ }^{112}$

Disse-se que o juro é o preço do capital, decorrente da comparação de diferentes situações de liquidez, composto em razão das disponibilidades monetárias, da preferência pela liquidez e da eficiência marginal dos capitais. Assim, a instituição financeira ao disponibilizar recursos monetários, a partir do negócio de crédito, cobra juros remuneratórios como o preço pela renúncia da liquidez e, juros moratórios como penalidade ao inadimplemento.

Para fixação da importância destes juros, são levados em conta todos os encargos a que o negócio se sujeita, tendo em vista o período temporal entre a concessão do crédito e a data avençada para a sua liquidação.

Note-se que com a previsão de fluência de juros remuneratórios resguarda-se o equilíbrio da relação jurídica, desde o momento da contratação até a data do vencimento da

${ }^{110}$ SOBRINHO, Ruy Cunha. Inadmissiblidade de cobrança da comissão de permanência pela via executiva. In: Simpósio sobre as condições gerais dos contratos bancários e a ordem pública econômica, 1988, Paraná. Anais Jurídicos I... Paraná: Juruá, 179p, p. 101-102, 1988, p. 101-102.

${ }^{111}$ Superior Tribunal de Justiça, AgRg nos ED no REsp. 604.470-RS, AgRg no REsp. 921.815-RS, AgRg no REsp. 973.549-RS.

${ }^{112}$ Vide BULGARELLI, Waldirio. A mora e a resolução 1.129 do Banco Central. Revista de Direito Mercantil, São Paulo, ano XXVI, n. 67, p. 71-81, jul-set, 1987 e MUNIZ, Francisco José Ferreira. Confronto de comissão de permanência e de correção monetária. In: Simpósio sobre as condições gerais dos contratos bancários e a ordem pública econômica, 1988, Paraná. Anais Jurídicos I... Paraná: Juruá, 179p, p. 75-79, 1988. 
obrigação e, com a previsão de fluência de juros moratórios, resguarda-se a punição ao devedor pelo inadimplemento, após o vencimento da obrigação.

O que ocorre, no entanto, quando o devedor não paga no prazo contratado? Se a liquidação não ocorre no vencimento, o credor fica privado de sua moeda em prazo superior ao avençado e, por conseguinte, há uma prorrogação do negócio, com sujeição de novos encargos e uma nova renúncia, ainda que forçada, sobre os quais a instituição financeira não será recompensada.

Quando se está diante do inadimplemento, portanto, as situações de liquidez se alteram, exigindo que a taxa de juros seja fixada num novo patamar, sob pena de romper o equilíbrio econômico-financeiro do contrato, ensejando o enriquecimento sem causa.

Por este motivo é que as taxas de juros moratórios não são suficientes para restabelecer o equilíbrio das situações de liquidez, pois a estas apenas compete punir o não pagamento no prazo avençado. Desta forma, uma vez que o Conselho Monetário Nacional não tem competência para regulá-los e sua disciplina se dá pelo Código Civil, fez-se necessária a criação de um elemento capaz de restaurar a equivalência entre as partes: a fluência de juros remuneratórios após o vencimento da obrigação, sob a denominação de comissão de permanência.

O próprio entendimento de que a comissão de permanência objetiva assegurar a equivalência de duas situações de liquidez é sinalizado pela determinação da cobrança desta comissão se dar em função da taxa pactuada no contrato original ou taxa média do mercado, impedindo que, diante do inadimplemento, tanto credor pratique juros muito além das taxas praticadas no mercado, quanto devedor isente-se dos encargos da sua inadimplência.

Daí tem-se que, a despeito de sua fluência coincidir com os juros moratórios, tendo em vista sua função de conservar a equivalência das situações de liquidez das partes que compõem o negócio jurídico de crédito, a comissão de permanência tem natureza de juros 
remuneratórios, contados após o vencimento da obrigação, com objetivo de restabelecer a equilíbrio das partes que contrataram o negócio jurídico de crédito. ${ }^{113}$

Neste sentido: "para aplacar eventuais controvérsias sobre o assunto, duas súmulas vieram a pacificar a jurisprudência daquela Corte (súmula 294 e 296 do Superior Tribunal de Justiça), deixando claro que a comissão de permanência é lícita, mas não passa de juros remuneratórios durante o período do inadimplemento, nada tendo a ver com correção monetária." 114

A confusão se inicia com a utilização equivocada da expressão comissão, que no discurso do direito, significa a paga ao comissionário civil ou comercial: "Na comissão não há mandato, mas outorga de poderes sem poder de representação. O comissionário recebe bens e os negocia. Os bancos, de fato, podem fazer jus à comissão na exata medida em que são comerciantes (...) o termo "comissão", é empregado ainda na equivalência de corretagem, que tal se entende a comissão ou paga à pessoa que serve de intermediaria em negócios, aproximando os interessados." 115 Falava-se em comissão de permanência porque o título permanecia da instituição financeira que descontou o crédito. Porém, a comissão, propriamente dita, é devida em face da outorga de poderes, enquanto que a comissão de permanência em face do atraso no pagamento dos débitos dos devedores com as instituições financeiras. Aquela flui desde o momento da contratação, enquanto esta desde o vencimento da obrigação. É evidente, pois, que não se confundem.

Da mesma forma, a despeito de serem inúmeras as manifestações no sentido de que sob a denominação de comissão de permanência seriam cobrados além de juros, correção monetária (o que fica evidenciado com a Súmula 30 do $\mathrm{STJ}^{116}$ ), não há como se confundir esta com aquela. A correção monetária consiste um percentual cuja expressão reflete a manutenção do poder aquisitivo da moeda e, desta forma, não implica em acréscimo ou decréscimo ao titular do instrumento monetário, diferentemente da comissão de permanência, que remunera o capital dado em empréstimo, refletindo a restauração do equilíbrio contratual rompido em razão do inadimplemento do débito. Aquela é calculada em razão das variações do preço de determinados bens ou serviços, ou do índice geral do

\footnotetext{
${ }^{113}$ Superior Tribunal de Justiça, AgRg no REsp 682.884 - RS 2004/0119457-4, voto do Ministro Ari Pargendler.

${ }^{114}$ São Paulo, Tribunal de Justiça, Ap. 7267198200.

${ }^{115}$ MIRANDA, Pontes de. Tratado de Direito Privado. Parte Especial. Tomo XLII. Ob. cit., p. 298.

${ }^{116}$ Súmula 30 do STJ: "A comissão de permanência e a correção monetária são inacumuláveis."
} 
custo de vida ou dos salários, enquanto que esta em razão das taxas pactuadas no contrato original ou da taxa de mercado do dia do pagamento. O decurso do tempo e a heterogeneidade do valor da moeda, portanto, é que justificam a correção monetária, já a comissão de permanência se justifica tendo em vista o inadimplemento da obrigação.

Ademais, o diploma legal sobre correção monetária e sobre comissão de permanência tem campos distintos de incidência e regulam matéria diversa. A comissão de permanência, cuja estipulação é facultada pela norma do Sistema Financeiro Nacional, editada com apoio no art. $4^{\circ}$ e $9^{\circ}$ da Lei $n^{\circ} 4.595 / 64$, regula a remuneração do capital nos negócios financeiros, já a correção monetária, instituída pela Lei $\mathrm{n}^{\circ} 6.899$, tem como campo de incidência qualquer débito resultante de decisão judicial, quando se tratar de execução por título extrajudicial, e o seu sentido é o de atualizar o valor da moeda em face dos efeitos inflacionários. ${ }^{117}$

Todavia, a despeito do inadimplemento da obrigação constituir suporte fático para a incidência da comissão de permanência, esta não se confunde com os juros moratórios. Já se esclareceu que a finalidade da comissão de permanência é remunerar o capital no período de inadimplência, sendo apenas necessário para sua cobrança o atraso no pagamento, enquanto que a finalidade dos juros moratórios é a de punir o inadimplente, sendo necessária para a sua cobrança a constituição do devedor em mora. Aquela se submete ao regime jurídico disciplinado pela Lei $n^{\circ} 4.595 / 64$, enquanto que este ao regime jurídico da mora, disciplinado pelo Código Civil.

Conclui-se, pois que, quando se fala em comissão de permanência, quer-se dizer juros remuneratórios cuja fluência se dá após o inadimplemento, diante da necessidade em se fixar a taxa de juros do negócio jurídico em um novo patamar, que leve em consideração a alteração das situações de liquidez.

${ }^{117}$ Superior Tribunal de Justiça, REsp. 103051/SP. 


\subsection{CUMULAÇÃO DE JUROS}

Temos assim i) juros remuneratórios, cuja fluência se dá desde a contratação do negócio jurídico ao vencimento da obrigação; ii) juros moratórios, cuja fluência se dá após o vencimento da obrigação; e iii) comissão de permanência ou juros remuneratórios, cuja fluência se dá durante o período do inadimplemento.

A dúvida que se impõe diz respeito à possível cumulação dos juros remuneratórios, moratórios e comissão de permanência, tendo em vista todos possuírem natureza jurídica de fruto civil, decorrentes do uso e fruição do capital dado em empréstimo.

Não há qualquer dificuldade ao se tratar de cumulação de juros remuneratórios e moratórios, em razão da peculiaridade de cada qual. Os primeiros devidos como recompensa pela renúncia da liquidez, os segundos decorrentes da mora. Ao termo de vencimento, o importe devido - composto por capital e juros remuneratórios - servirá de base de cálculo para incidência de juros moratórios, sem que tal prática constitua anatocismo. $^{118}$

A problemática decorre da confusão que se faz primordialmente no tocante à comissão de permanência, quando a ela se refere equivocadamente como o encargo que abrange juros e correção monetária, e não como juros remuneratórios após o vencimento.

A súmula 296 do Superior Tribunal de Justiça ${ }^{119}$, ao determinar que os juros remuneratórios devidos no período da inadimplência, não são cumuláveis com a comissão de permanência, evidencia a má compreensão sobre o assunto, visto que este não se diferencia daquele.

Do período desde a contratação à data do vencimento, fluem juros denominados remuneratórios, após o vencimento e durante o período de inadimplência, continuam fluindo juros remuneratórios, contudo, denominados comissão de permanência. Desta forma, falar em cumulação de juros remuneratórios e comissão de permanência é falar em

\footnotetext{
${ }^{118}$ Superior Tribunal de Justiça, REsp. 402483 (2002/0000391-4 - 05/05/2003).

${ }^{119}$ Súmula 296 do STJ: “Os juros remuneratórios, não cumuláveis com a comissão de permanência, são devidos no período de inadimplência, à taxa média de mercado estipulada pelo Banco Central do Brasil, limitada ao percentual contratado."
} 
fluência de juros remuneratórios desde o momento da contratação até o período de inadimplência, inclusive.

Na prática, havendo ajuste contratual de comissão de permanência, após o vencimento da obrigação fluem juros à taxa pactuada no contrato original ou à taxa de mercado do dia do pagamento (Resolução 1.129 de 15.05.1986 do Banco Central do Brasil) e, em não havendo ajuste contratual, a despeito do caráter dispositivo da comissão de permanência, o negócio financeiro fica sujeito a fluência de juros remuneratórios após o vencimento à taxa de mercado, limitada ao percentual contratado (Súmula 296 do STJ).

Quanto à possibilidade de cumulação da comissão de permanência com os juros moratórios, além da própria norma do Conselho Monetário Nacional autorizá-la ("podem cobrar (...) além de juros de mora na forma da legislação em vigor, comissão de permanência" ${ }^{120}$ ), resta evidenciado que os dois institutos não se confundem. Disse-se, no capítulo anterior, que se diferenciam: i) quanto a finalidade - dos juros moratórios é de punir o inadimplente, e estimulá-lo a cumprir sua obrigação no tempo, lugar e forma devidos, enquanto que da comissão de permanência é de remunerar o titular do capital pelo uso do dinheiro no tempo; ii) quanto ao fundamento - a incidência daquele decorre da lei, enquanto que a incidência da comissão de permanência, da vontade das partes; iii) quanto ao regime - o juro moratório submete-se ao regime jurídico da mora, disciplinado pelo Código Civil, enquanto que a comissão de permanência submete-se ao regime jurídico disciplinado pela Lei $\mathrm{n}^{\circ} 4.595 / 64^{121}$. Por conseguinte, a despeito de algumas manifestações em sentido contrário ${ }^{122}$, não há como admitir que comissão de permanência e juros moratórios são inacumuláveis.

No tocante à correção monetária, já restou evidenciada sua diferenciação com a comissão de permanência. Quando analisada sua possível cumulação em face da natureza de cada qual, o próprio Supremo Tribunal Federal já se pronunciou pela sua admissibilidade $^{123}$. Todavia, sobre este assunto as controvérsias não decorrem da confusão entre os diferentes institutos, mas do entendimento que a comissão de permanência

\footnotetext{
${ }^{120}$ Resolução 1.129 de 15.05.1986 do Banco Central do Brasil.

${ }^{121}$ OLIVEIRA, Marcos Cavalcante de. Comissão de permanência: legalidade e necessidade. Revista de Direito Bancário, São Paulo, ano 9, n. 33, p. 33-60, jul-set 2006.

${ }^{122}$ Superior Tribunal de Justiça, AgRg no REsp. 801072/RS, 2005/0198163-0, AgRg no REsp. 706368/RS, 2004/0169391-0.

${ }^{123}$ Supremo Tribunal Federal, RE 103051/SP.
} 
expressaria uma taxa em cujo valor estaria incluído um elemento destinado a atualização monetária do capital, motivo pelo qual sua cobrança vedaria a possibilidade de cobrar a correção monetária, sob pena de configurar bis in idem, nos termos da Súmula 30 do STJ $^{124}$.

O equívoco que se comete, nesta interpretação, é o de que as taxas que serviriam de referência para a fixação da comissão de permanência seriam prefixadas, de tal sorte que conteriam a neutralização do efeito inflacionário. ${ }^{125}$

A discussão, no entanto, não se resolve no âmbito das taxas prefixadas. A comissão de permanência pode fundamentar-se em taxas pré-fixadas ou pós-fixadas ${ }^{126}$. Naquelas teremos um percentual fixo sobre o valor nominal do capital dado em empréstimo, sem que haja alteração no período de vigência do contrato. Nestas teremos um percentual fixo sobre o valor do capital depois de ter sido levado em conta a aplicação de um índice de preço ou juros previamente acordado. ${ }^{127}$

Desta forma, há quem se posicione no sentido de que o regime a que se submete a comissão de permanência a taxas pré-fixadas se diferencia daquele que se submete a comissão de permanência a taxas pós-fixadas:

"Se as partes convencionarem, para o prazo normal da operação, juros a taxas prefixadas, aplica-se a Súmula 30 do STJ: a comissão de permanência terá que seguir a mesma modalidade de taxa e não será acumulável com a correção monetária. Se as partes convencionarem, para o prazo normal da operação, juros compensatórios a taxas pósfixadas, a Súmula 30 do STJ não incide sobre a hipótese e a comissão de permanência terá que ser estimada com base na taxa (pós-fixada) contratada ou na taxa (também pós-fixada de mercado)."128

Contudo, uma vez demonstrado que o efeito inflacionário não orienta a formação da taxa de juros e, por conseguinte, a comissão de permanência, mas pelo contrário, apenas

\footnotetext{
${ }^{124}$ Súmula 30 do STJ: "A comissão de permanência e a correção monetária são inacumuláveis."

${ }^{125}$ SCAVONE, 2003.

${ }^{126}$ Circular 2.905 de 30.06.1999 do Banco Central do Brasil.

${ }^{127}$ OLIVEIRA, Marcos Cavalcante de. Comissão de permanência: legalidade e necessidade. Revista de Direito Bancário, São Paulo, ano 9, n. 33, p. 33-60, jul-set 2006.

${ }^{128}$ Ibid.
} 
incide no valor do capital dado em empréstimo com a finalidade de manter o valor da moeda, acompanho o entendimento mencionado do Supremo Tribunal Federal no sentido da possibilidade de sua cumulação com a correção monetária.

Quanto aos demais encargos, é importante ressaltar que o inadimplemento da obrigação e a constituição do devedor em mora não geram apenas a possibilidade da cobrança de comissão de permanência e juros moratórios, mas, além, de perdas e danos e cláusula penal, nos termos dos arts. 404 e 408 do Código Civil. É necessário, portanto, elucidar como, nas dívidas de dinheiro, operacionalizam a cumulação entre a comissão de permanência, os juros decorrentes da mora, as perdas e danos e a cláusula penal.

Em relação aos juros remuneratórios após o inadimplemento e aos demais encargos, a própria Resolução 1.129 do Banco Central, ao criar a comissão de permanência, vedou a cobrança de quaisquer outras quantias compensatórias pelo atraso no pagamento dos débitos vencidos ${ }^{129}$, exceto de juros decorrentes da mora, de maneira que não se permite a cumulação da comissão de permanência com perdas e danos e cláusula penal. $^{130}$

Para a exigência da cláusula penal, assim como dos juros moratórios, não é necessário que se comprove prejuízos decorrentes da mora do devedor, diferentemente das perdas e danos em que há a necessidade da prova do que efetivamente o credor perdeu, bem como do que deixou de lucrar. O art. 404 do Código Civil deixa claro que o instituto de perdas e danos abrange juros moratórios e, além, que em sendo estes insuficientes para cobrir o prejuízo, em não havendo cláusula penal, pode o juiz conceder ao credor indenização suplementar.

Conclui-se pois que, diante de perdas e danos e juros moratórios avençados no contrato, cobram-se juros moratórios adicionados a indenização suplementar até o limite do prejuízo do credor em razão da mora do devedor. Entretanto, diante de cláusula penal e

\footnotetext{
${ }^{129}$ Resolução 1.129 do Banco Central do Brasil: “(...) podem cobrar de seus devedores por dia de atraso no pagamento ou na liquidação de seus débitos, além de juros de mora na forma da legislação em vigor, comissão de permanência calculada as mesmas taxas pactuadas no contrato original ou a taxa de mercado do dia do pagamento, não sendo permitida a cobrança de quaisquer outras quantias compensatórias pelo atraso no pagamento dos débitos vencidos".

${ }^{130}$ Nos negócios financeiros o atraso no pagamento não implica inexecução, pois ainda há a possibilidade de receber o valor devido, acrescido de todos os encargos moratórios (juros moratórios, comissão de permanência, e multa convencional), de forma que ao se falar em cláusula penal quer-se tratar apenas da espécie moratória e não compensatória, que se justifica em razão do inadimplemento absoluto.
} 
juros moratórios avençados no contrato, cobram-se juros moratórios e multa contratual sem que se possa exigir indenização suplementar de prejuízo excedente, nos termos do parágrafo único do art. 416 do mesmo diploma legal. 


\subsection{LIMITAÇÃO DA TAXA DE JUROS}

No ordenamento jurídico brasileiro, a taxa de juros foi regulamentada pela primeira vez pelo Alvará de 05 de maio de 1810, que permitia no empréstimo de dinheiro para o comércio marítimo a cobrança de certo prêmio, em razão do risco desta atividade. Posteriormente, a Lei de Regência Trina, de 24 de outubro de 1832, determinava a liberdade de contratação quanto aos juros, sem qualquer limite de valor ou tempo. ${ }^{131}$

Em 1850, com a promulgação do Código Comercial, tal liberdade foi mantida, com a reprodução parcial do texto da antiga Lei de 1832 , em seu art. $248^{132}$. No entanto, nota-se que tal liberdade admitiu restrições, visto que a cobrança de juros estaria permitida apenas nos casos assinalados ou permitidos neste diploma legal.

O Código Comercial disciplinava a taxa de juros de maneira mais detalhada, prevendo em seu art. 138 que, para os contratos e obrigações mercantis (exceto no caso de compra e venda mercantil), os efeitos da mora contar-se-iam a partir do dia em que o credor, após o vencimento, exigisse judicialmente o pagamento e seriam devidos, quando não estipulados, apenas os juros moratórios. ${ }^{133}$ Sob o título XI: "Do mútuo e dos juros mercantis", o referido diploma legal previu regras acerca da contagem dos juros e se preocupou em regulamentar os juros moratórios ${ }^{134}$.

${ }^{131}$ SCAVONE 2003, p. 35.

132“Art. 248 - Em comércio podem exigir-se juros desde o tempo do desembolso, ainda que não sejam estipulados, em todos os casos em que por este Código são permitidos ou se mandam contar. Fora destes casos, não sendo estipulados, só podem exigir-se pela mora no pagamento de dívidas líquidas, e nas ilíquidas só depois da sua liquidação" Lei nº 556, de 25 de Junho de 1850.

133“"Art. 138 - Os efeitos da mora no cumprimento das obrigações comerciais, não havendo estipulação no contrato, começam a correr desde o dia em que o credor, depois do vencimento, exige judicialmente o seu pagamento. Havendo estipulação de juros sem declaração do quantitativo, ou do tempo, presume-se que as partes convieram nos juros da lei, e só pela mora (artigo $n^{\circ}$. 138)". Lei no 556 , de 25 de Junho de 1850.

134“A Art. 249 - Nas obrigações que se limitam ao pagamento de certa soma de dinheiro, os danos e interesses resultantes da mora consistem meramente na condenação dos juros legais.

Art. 250 - O credor que passa recibos ou dá quitação de juros menores dos estipulados não pode exigir a diferença relativa ao vencimento passado; todavia, os juros futuros não se julgam por esse fato reduzidos a menos dos estipulados.

Art. 251 - O devedor que paga juros não estipulados não pode repeti-los, salvo excedendo a taxa da lei; e neste caso só pode repetir o excesso, ou imputá-lo no capital.

Art. 252 - A quitação do capital dada sem reserva de juros faz presumir o pagamento deles, e opera a descarga total do devedor, ainda que fossem devidos. 
Em 1916, sob a égide do liberalismo, o Código Civil é promulgado, privilegiando a liberdade da taxa de juros. É o que se extrai dos seus arts. 1.062 e 1.063 , que determinava que a taxa de juros moratórios fosse de $6 \%$ ao ano quando não convencionada, bem como quando devido por força de lei ou por contrato sem convenção de taxa estipulada.

Desta forma, todos os contratos celebrados sob seu amparo poderiam estipular juros sem qualquer limitação, sejam juros remuneratórios ou moratórios, decorrentes de negócios de crédito ou de negócios a crédito. Ainda quando não convencionados, aplicarse-iam taxas de $6 \%$ ao ano.

Em 1929, todavia, esta liberdade que restou por estipular uma remuneração excessiva do capital, agravou-se à época da crise do café, decorrente da Grande Depressão, culminando numa restrição da relação entre produção e consumo que fundamentavam a atividade produtiva do Estado.

Naquela época a produção agrícola sustentava a economia nacional, primordialmente com o cultivo do café que, no entanto, convivia com a problemática do crescimento da oferta superar o da demanda. Com a recessão econômica decorrente da Crise de 29, não apenas a demanda internacional reduziu-se abruptamente, bem como os recursos utilizados pelo governo brasileiro para controle da oferta sofreram grande restrição (que até então se fundamentavam na compra de sacas excedentes pelo governo brasileiro e em empréstimos financiados por tributos cobrados sobre a exportação do produto).

Assim, como controle da usura e, mais além, como medida de política econômica, surgiu o Decreto-Lei 22.626 de 1933, que viria a limitar a prática da taxa de juros, determinando que aquele que praticasse juros superiores ao dobro da taxa legal cometeria crime de usura:

Art. 253 - É proibido contar juros de juros; esta proibição não compreende a acumulação de juros vencidos aos saldos liquidados em conta corrente de ano a ano.

Depois que em juízo se intenta ação contra o devedor, não pode ter lugar a acumulação de capital e juros.

Art. 254 - Não serão admissíveis em juízo contas de capital com juros, em que estes senão acharem reciprocamente lançados sobre as parcelas do débito e crédito das mesmas contas. Lei $n^{\circ} 556$, de 25 de Junho de 1850." 
"No Brasil, o Governo instalado após a Revolução de 1.930 viu-se a braços com os efeitos da crise de 1.929 e adotou várias medidas de reordenamento econômico. Dentre elas, interessando especificamente à taxa de juros, editou-se o Dec. 22.626, de 7.4.33... A seletividade da taxa, em função da garantia ou do destino do empréstimo, só podia encontrar sua razão em fatores de ordem econômica, pois ainda no começo da década de 30 era a agricultura que sustentava a economia nacional As rigorosas disposições desse diploma, associadas à inflação que já na mesma época se verificava no Brasil, haviam de levas as duas conseqüências: a retração na atividade econômica, de um lado, e a burla, de outro." 135

Ora, sendo o Decreto-Lei espécie normativa com força de lei ordinária e, tendo em vista que a taxa de juros legais, prevista no Código Civil de 1916, respeitava o patamar de $6 \%$ ao ano, a consequiência que se colhia era a limitação da prática de juros, remuneratórios ou moratórios, convencionais ou legais, em taxas nunca superiores a $12 \%$ ao ano. ${ }^{136}$

Certo é que as Constituições supervenientes acompanharam a repressão a usura, acolhendo o disposto no referido Decreto-Lei, e dispuseram:

“Art 117 - ...

Parágrafo único - É proibida a usura, que será punida na forma da Lei." (Constituição Federal de 1.934)

"Art 142 - A usura será punida." (Constituição Federal de 1.937)

Contudo, a estipulação de uma taxa fixa de juros confrontava os parâmetros de equivalência das situações de liquidez, que se expressam em função das disponibilidades monetárias e da eficiência marginal dos capitais. A problemática desta estipulação estava no fato de não levar em conta a flutuação do poder de compra da moeda e alterações nas situações de liquidez, de maneira que a não preservação do equilíbrio do contrato colhia desvantagens tanto ao concedente de crédito, que em alta inflacionária enriquecia o devedor, como ao adquirente, que em caso de deflação, enriquecia o credor.

\footnotetext{
${ }^{135}$ Parecer SR 70 DOU 7.10.88.

${ }^{136}$ Outras consequiências eram observadas em face do referido diploma legal, que também vedava à prática ao anatocismo, declaravam nulos os contratos celebrados em confronto a esta lei e tipificava o crime de usura. Contudo, o presente capítulo tem por intuito apenas tratar sobre a limitação da taxa de juros.
} 
Em 1938, todavia, sobreveio o Decreto-Lei 869, cujo lineamento, viria a ser adotado nos termos da Lei ${ }^{\circ} 1.521 / 1951$, regulamentando a Usura Real e tipificando como crime contra a econômica popular obter ou estipular, em qualquer contrato, lucro patrimonial que exceda o quinto do valor corrente ou justo da prestação feita ou prometida (art. $4^{\circ}$, letra "b") ${ }^{137}$. Conseqüentemente, restaria vedado pelo referido dispositivo a prática de juros remuneratórios no importe superior a $20 \%$ da prestação principal.

A despeito da distinção das modalidades de Usura, a Constituição Federal de 1946, acompanhando o entendimento dos antigos diplomas legais, viria a condenar a usura nominal e real ${ }^{138}$, conforme disciplinou o art. 154 , "in verbis":

"Art 154 - A usura, em todas as suas modalidades, será punida na forma da lei."

Inovando o ordenamento jurídico, o advento da Lei $\mathrm{n}^{\circ} 4.595 / 1964$, atribuiria, por força de seu art. $4^{\circ}$, inciso IX, competência ao Conselho Monetário Nacional de limitar, sempre que necessário, as taxas de juros, descontos comissões e qualquer outra forma de remuneração de operações e serviços bancários ou financeiros, calando-se no tocante aos juros decorrentes da mora.

Manifestou a jurisprudência o entendimento de que o dispositivo se tratava de uma derrogação, visto que nos casos de operações pertinentes ao Sistema Financeiro Nacional incidiria a regra prevista na Lei 4.595, sem se submeter aos limites estabelecidos pelo Decreto 22.626, conservando-se tal limitação, no entanto, aos demais casos.

Neste sentido, sumulou o Supremo Tribunal Federal, sob o nº 596: “As disposições do Decreto 22626/1933 não se aplicam às taxas de juros e aos outros encargos cobrados nas operações realizadas por instituições públicas ou privadas, que integram o Sistema Financeiro Nacional."

137 “Art. $4^{\circ}$ Constitue crime da mesma natureza a usura pecuniária ou real, assim se considerando:

b) obter ou estipular, em qualquer contrato, abusando da premente necessidade, inexperiência ou leviandade da outra parte, lucro patrimonial que exceda o quinto do valor corrente ou justo da prestação feita ou prometida."

${ }^{138}$ Juros nominal e juros real vide capítulo 4.1 . 
Foi este o primeiro momento em que se distinguiu o regime jurídico, a regular os negócios de crédito e os negócios a crédito, no tocante aos juros. Naqueles, as taxas seriam fixadas pelo Conselho Monetário Nacional, restando apenas aos negócios mercantis limitação aos critérios nominais enunciados pela Lei da Usura.

Aliando-se a esta superação, a Constituição Federal de 1967 limitou-se a enunciar como princípio da ordem econômica e social a repressão ao abuso do poder econômico, caracterizado pelo domínio dos mercados, a eliminação da concorrência e o aumento arbitrário dos lucros (art. 157, inciso VI), abstendo-se de pronunciar sobre norma específica referente à usura.

Livres taxas de juros, em negócio financeiro, voltavam a ser praticadas no mercado, até o advento da Constituição Federal de 1988 que, contrariando a evolução dos entendimentos acerca da taxa nominal de juros, voltou a estipulá-la, por força de seu art. 192, parágrafo $3^{\circ}$ : “As taxas de juros reais, nelas incluídas comissões e quaisquer outras remunerações direta ou indiretamente referidas à concessão de crédito, não poderão ser superiores a doze por cento ao ano; a cobrança acima deste limite será conceituada como crime de usura, punido, em todas as suas modalidades, nos termos que a lei determinar."

Pelo disposto, competia ao Banco Central comprar e vender títulos emitidos pelo Tesouro com o objetivo de regular a taxa de juros (art. 164, parágrafo $2^{\circ}$ ), sem que estas taxas pudessem exceder doze por cento ao ano; sob pena de configurar crime de usura.

No dia imediatamente subseqüente à publicação em Diário Oficial da Magna Carta, foi publicado parecer da Consultoria Geral da República, sob o $\mathrm{n}^{\circ} 70$, interpretando o dispositivo mencionado que, com aprovação do Presidente da República, adquiriu caráter normativo, conforme teor do parágrafo $2^{\circ}$ do art. 22 do Decreto ${ }^{\circ} 92.889 / 1926^{139}$.

Sobre técnica legislativa, dizia o referido parecer que os parágrafos de um artigo teriam a finalidade de ordená-lo ou excepcioná-lo, e que, o art. 192, ao enunciar em seu "caput" que lei complementar "disporá inclusive sobre" evidenciou que competirá a esta espécie normativa regular inclusive as matérias contidas em seus incisos e parágrafos.

${ }^{139}$ “Art $22(\ldots) \& 2^{\circ}$ O parecer aprovado e publicado, juntamente com o despacho presidencial, adquire caráter normativo para a Administração federal, cujos órgãos e entes ficam obrigados a lhe dar fiel cumprimento." 
Quanto ao mérito discutia que juros é matéria estranha a Constituição e, afirmava que a sua limitação sem uma reforma completa no Sistema Financeiro Nacional acarretaria conseqüências catastróficas no cenário econômico.

Donde finalmente concluía que o parágrafo $3^{\circ}$ do art. 192 era preceito constitucional que dependia do legislador ordinário para sua plena realização.

Nesta exegese, o Banco Central do Brasil emitiu Circular, sob o $\mathrm{n}^{\circ}$ 1.365, ratificando os termos do Parecer, no sentido de que as operações praticadas por instituições do Sistema Financeiro Nacional sujeitar-se-iam aos termos da Lei $\mathrm{n}^{\circ} 4.595$, até o advento de lei complementar nos termos do art. 192 da Magna Carta.

A despeito da técnica legislativa, certo é que o ato normativo da Consultoria Geral da República, bem como a Circular do Banco Central, restariam por fixar a compreensão do dispositivo constitucional no sentido de tratar-se norma constitucional de eficácia limitada, sendo que a taxa de juros, em negócio financeiro, não se restringiria à limitação do parágrafo $3^{\circ}$ art. 192 da Constituição Federal.

A conseqüência imediata que se observava era a não limitação dos juros remuneratórios em negócios financeiros, ao que dispunha o art. $4^{\circ}$, inciso IX da Lei $\mathrm{n}^{\circ}$ 4.595/1964. Todavia foram muitos os doutrinadores e juristas que se manifestaram em sentido contrário, baseando seus fundamentos primordialmente no tocante a: i) aplicabilidade da norma constitucional; ii) interpretação do art. $4^{\circ}$, inciso IX da Lei $\mathrm{n}^{\circ}$ 4.595/1964; iii) competência para legislar acerca da matéria financeira.

Em relação ao primeiro aspecto, contradisseram o entendimento de que o referido dispositivo tratar-se-ia de norma constitucional de eficácia limitada, argumentando que o parágrafo $3^{\circ}$ do art. 192 da Constituição Federal, ao dizer que os juros reais não deverão exceder $12 \%$ ao ano e a eles não se somarão remunerações de nenhuma natureza, direta ou indiretamente, disse tudo que era necessário para sua imediata aplicação, de tal sorte que se trataria de norma constitucional de eficácia plena. ${ }^{140}$

Não é possível pressupor, todavia, que os parágrafos de um artigo sejam postos desde logo em vigor, enquanto o enunciado principal aguarda sua regulação por lei

\footnotetext{
${ }^{140}$ Supremo Tribunal Federal, ADIn. 04/DF.
} 
complementar, mesmo porque é este que justifica a criação daqueles, uma vez que aos parágrafos compete desdobrar o conteúdo do enunciado principal.

Em relação ao segundo aspecto, diziam que a atribuição de competência ao Conselho Monetário Nacional (CMN) para fixar taxa de juros nos termos da Lei $\mathrm{n}^{\circ}$ 4.595/1964 estaria adstrita aos limites da Lei da Usura, podendo ser limitados, e não liberados, donde se concluía que o Conselho Monetário poderia fixar taxa de juros, até o limite dos percentuais ordenados pelo Código Civil de 1916 e pelo Decreto-Lei $22.626 / 1933 .{ }^{141}$

Contudo, a referida atribuição de competência teve a finalidade de garantir a fixação dos parâmetros dos juros não apenas assegurando a equivalência entre situações de liquidez, mas além, em função dos mecanismos de controle da moeda e do crédito, tendo em vista as peculiaridades de efeitos que se colhem do juro praticado em negócio financeiro, o que seria impossível diante da sua limitação em termos nominais (vide capítulo 4.1.).

Finalmente, quanto a competência para legislar acerca de matéria financeira, pontuavam que o inciso XIII do art. 48, combinado com parágrafo $1^{\circ}$ do art. 68 e art. 25 dos Atos das Disposições Constitucionais Transitórias (ADCT), da Constituição Federal, deixavam claro a revogação da competência ao Conselho Monetário Nacional a legislar sobre matéria financeira, entendimento este que alcança hoje o Tribunal de Justiça do Rio Grande do Sul:

"Revogação da Lei n. 4.595/64 atributiva de poder normativo ao Conselho Monetário Nacional em matéria de competência legislativa do Congresso Nacional com o advento da Constituição Federal de 1988, por força do artigo 25 do ADCT, revogadas ficaram todas as instruções normativas $e$, de resto, o próprio poder normativo em matéria de competência legislativa do Congresso Nacional, por conseguinte o poder normativo a respeito de juros bancários que a Lei n. 4595/64 concedia ao Conselho Monetário Nacional restou revogado. A única lei federal limitativa de juros é a lei da usura que hoje regra os contratos de toda a sociedade, inclusive os bancários." 142

\footnotetext{
${ }^{141}$ RIZZARDO, 2000, p. 357.

${ }^{142}$ Rio Grande do Sul, Tribunal de Justiça, Ap. 196006639.
} 
Com efeito, a despeito do art. 25 da ADCT revogar todos os dispositivos legais que atribuam ou deleguem a órgão do Poder Executivo competência assinalada pela Constituição ao Congresso Nacional e, a despeito do parágrafo $1^{\circ}$ do art. 68 da $\mathrm{CF}$ vedar a delegação dos atos de competência exclusiva do Congresso Nacional, certo é que, em razão do fenômeno da recepção, a nova constituição recebe normas infraconstitucionais anteriores, desde que não a contrarie materialmente. São apenas as normas elaboradas após a constituição que devem respeitá-la materialmente e formalmente. Donde se extrai que, apesar da Magna Carta ter conferido competência ao Congresso Nacional regular em lei complementar o sistema financeiro, a teor do que dispõe o art. 48, inciso III, até que não advenha o referido diploma legal, a Lei ${ }^{\circ} 4.595 / 64$ continua em vigor, pois recepcionada pela constituição.

Assim a constitucionalidade dos atos normativos supra mencionados restariam declarados em sede de ADIn 004/DF, no sentido de que o dispositivo constitucional em comento tratar-se-ia de norma de eficácia limitada, bem como os negócios financeiros reger-se-iam pela Lei ${ }^{\circ} 4.595 / 64$, tendo o Supremo Tribunal Federal decidido que:

"não é de se admitir a eficácia imediata e isolada do disposto em seu parágrafo $3^{\circ}$, sobre taxa de juros reais $(12$ por cento ao ano), até porque estes não foram conceituados. Só o tratamento global do Sistema Financeiro Nacional, na futura lei complementar, com a observância de todas as normas do "caput", dos incisos e parágrafos do art. 192, e que permitira a incidência da referida norma sobre juros reais e desde que estes também sejam conceituados em tal diploma. Em conseqüência, não são inconstitucionais os atos normativos em questão (parecer da Consultoria Geral da República, aprovado pela Presidência da República e Circular do Banco Central), o primeiro considerando não auto aplicável a norma do parágrafo $3^{\circ}$ sobre juros reais de 12 por cento ao ano, e a segunda determinando a observância da legislação anterior a Constituição de 1.988, até o advento da Lei Complementar reguladora do Sistema Financeiro Nacional. (Rel. Min. Sydney Sanches, DJ 25.6.1993)

A Emenda Constitucional $\mathrm{n}^{\circ} 40$ de 29.05.2003 oficializaria o referido entendimento, revogando todos os incisos, letras e parágrafos, e reformando o art. 192 da 
Constituição Federal, cuja redação passou a constar: "O sistema financeiro nacional, estruturado de forma a promover o desenvolvimento equilibrado do País e a servir aos interesses da coletividade, em todas as partes que o compõem, abrangendo as cooperativas de crédito, será regulado por leis complementares que disporão, inclusive, sobre a participação do capital estrangeiro nas instituições que o integram"

Superada esta problemática, algumas alterações acerca da matéria de juros seriam colhidas com o advento do Código Civil de 2002. A primeira delas dizia respeito ao patamar da taxa a ser observada em casos de juros legais, ou convencionais quando não estipulados, com a substituição do importe de $6 \%$ ao ano pela taxa que estiver em vigor para a mora do pagamento de impostos devidos à Fazenda Nacional (arts. 406 e 591).

A discussão que se impõe, nesta oportunidade, diz respeito à eventual antinomia entre o novo diploma legal e a Lei ${ }^{\circ}$ 4.595/64. Contudo a própria súmula 596 do Supremo Tribunal Federal ${ }^{143}$ consolidou o entendimento de que não há como se afastar a especialidade da Lei $\mathrm{n}^{\circ} 4.595 / 64$, visto que a ela compete dispor sobre o Sistema Financeiro Nacional, em detrimento aos demais diplomas legais, tendo inclusive o Superior Tribunal de Justiça se manifestado acerca da não aplicação do art. 591 do Código Civil aos negócios de crédito ${ }^{144}$.

Ainda, a despeito da elaboração da Lei $n^{\circ}$ 4.595/64 sob a égide da Constituição de 1946, certo é que foi recepcionada pela Constituição de 1988, passando a vigorar com força de lei complementar, nos termos do art. 192 da Magna Carta.

Com efeito, os juros remuneratórios no negócio de crédito submetem-se a regime jurídico distinto ao dos juros remuneratórios no negócio a crédito. Todavia, a despeito de não se orientar pelos limites impostos pelo Decreto-Lei 22626/33 e, a despeito de não haver previsão expressa de sua limitação nos termos da Lei $n^{\circ} 4.595 / 64$, as considerações acerca dos elementos que conformam a taxa de juros nos socorrem para orientar os limites que podem ser exigíveis.

\footnotetext{
${ }^{143}$ Súmula 596: “As disposições do Decreto 22626/1933 não se aplicam às taxas de juros e aos outros encargos cobrados nas operações realizadas por instituições públicas ou privadas, que integram o Sistema Financeiro Nacional."

${ }^{144}$ Superior Tribunal de Justiça, REsp. 1.061.530 - RS (2008/0119992-4).
} 
Consoante os juros moratórios, que se submetem ao regime jurídico da mora disciplinado pelo Código Civil, aplicar-se-á quando não forem convencionados, ou o forem sem taxa estipulada, ou quando provierem de determinação da lei, os juros fixados segundo a taxa que estiver em vigor para a mora do pagamento de impostos devidos à Fazenda Nacional, nos termos do art. 406 do Código Civil.

Todavia, no tocante às cédulas de crédito rural, industrial e comercial, os juros moratórios limitam-se à elevação de $1 \%$ ao ano sobre a taxa contratada, no que dispõe o parágrafo único do art. $5^{\circ}$ do Decreto-lei $167 / 1967^{145} \mathrm{e}$, quanto aos títulos de crédito, a taxa de $6 \%$, nos termos do art. 48 da Lei Uniforme ${ }^{146}$.

Quanto aos limites da comissão de permanência, tendo em vista o teor da Resolução 1.129 do Banco Central do Brasil, haverá de ser fixado à taxa pactuada no contrato original ou à taxa de mercado do dia do pagamento. Ressalta-se que, em confronto com algumas manifestações ${ }^{147}$, a comissão de permanência apenas limitar-se-á a taxa do contrato, nos termos da Súmula 296 do STJ, quando não pactuada, pois, do contrário, perderia sua natureza de juros remuneratórios. ${ }^{148}$

Disse-se que o juro é o preço do capital que se compõem em função das disponibilidades monetárias, da preferência pela liquidez e da eficiência marginal dos capitais. Portanto, concluiu-se que os juros remuneratórios hão de expressar uma taxa que assegure a relação de equivalência entre duas situações de liquidez, orientada pelo interesse da coletividade, pelas relações de mercado, e pela participação do Estado, sob os critérios do equilíbrio econômico-financeiro do contrato e da vedação ao enriquecimento sem causa.

\footnotetext{
145“"Parágrafo único. Em caso de mora, a taxa de juros constante da cédula será elevável de 1\% (um por cento) ao ano."

146“'Art. 48: O portador pode reclamar daquele contra quem exerce o seu direito de ação: Uniforme).

$2^{\circ}$ os juros à taxa de 6\% (seis por cento) desde a data do vencimento" Decreto 57.663/1966 (Lei

${ }^{147}$ Superior Tribunal de Justiça, AgRg no REsp 440182/RS 2002/0065631-8, REsp 627511/GO 2004/0013338-7

148“A função social e econômica dessa comissão é justamente proteger credor quando ocorre de ele se ver obrigado a refinanciar o empréstimo concedido e não pago no vencimento a um custo superior ao contratado originalmente. Se os juros compensatórios ficassem limitados à taxa do contrato, não terá qualquer utilidade a cláusula contratual de comissão de permanência. Em relação ao devedor, a comissão de permanência também se tornaria uma irrelevância, pois o credor - limitado à taxa do contrato - optaria sempre pela taxa do contrato, deixando de lado a comissão e cobrando, aí sim, a correção monetária, a multa e até, a indenização suplementar prevista no art. 406 do CC." OLIVEIRA, Marcos Cavalcante de. Comissão de permanência: legalidade e necessidade. Revista de Direito Bancário, São Paulo, ano 9, n. 33, p. 33-60, jul-set 2006.
} 
Desta forma, para a completa compreensão acerca dos patamares aos quais se submetem as taxas de juros praticadas em negócios financeiros, faz-se necessário algumas breves considerações acerca dos princípios gerais que orientam nosso direito.

A unidade de sentido que fundamenta as normas dum sistema jurídico é composta pelos princípios gerais de direito. Esses critérios gerais são a conexão aglutinadora das normas jurídicas, cuja função é a de libertar os valores singulares compreendidos no ordenamento de seu isolamento aparente. ${ }^{149}$

São duas as colunas sobre as quais se assentam as relações de conteúdo patrimonial: o princípio do equilíbrio econômico-financeiro e o princípio da vedação ao enriquecimento sem causa. $^{150}$

O princípio do equilíbrio econômico-financeiro está fundamentado na noção de equivalência, tratada no capítulo 2.1., do qual vale reiterar que, em se tratando da matéria de juros, o equivalente não se perfaz pelo equilíbrio dos egoísmos consubstanciados na justa proporção entre prestação e contraprestação dos contratos de intercâmbio.

Isto ocorre porque o negócio financeiro colhe efeitos para além da relação contratual, tendo em vista as funções que o instrumento monetário desempenha na ordem social, de liquidez e procura efetiva. Portanto, o equivalente da taxa de juros compõe-se em razão da comparação entre essas diferentes situações de liquidez que, por sua vez, não se dissociam do comportamento das disponibilidades monetárias e da eficiência marginal do capital.

Disse-se àquela ocasião que as variações quantitativas das disponibilidades monetárias se expressam em razão da equação $\mathrm{MV}=\mathrm{PT}$ e que, a preferência pela liquidez dependerá das motivações de renda, negócio, precaução e especulação.

A análise do motivo especulação e o conhecimento do conjunto de reações provocado pelos mecanismos econômicos na ordem social revelaram outra variável imprescindível para a visão adequada do assunto: a atuação do Estado, sobre a economia e na economia.

\footnotetext{
${ }^{149}$ CANARIS, 1989.

${ }^{150}$ CHIARA, José Tadeu de. moeda e a ordem jurídica. Ob. cit.
} 
Desta forma, os elementos que devem ser levados em consideração para o rigoroso cumprimento da noção de equivalência entre situações de liquidez e, por conseguinte, para a prática de uma taxa de juros que resguarde o equilíbrio econômico-financeiro da relação, são: o interesse da coletividade (traduzido pelo sentimento de egoísmo que orienta a opção de buscar da melhor forma a satisfação de sua necessidade em condições vantajosas); as relações de mercado (decorrente das disponibilidades monetárias, da preferência pela liquidez, e da eficiência marginal dos capitais) e; a participação do Estado (ora como agente econômico, ora como autoridade monetária).

A não expressão deste equilíbrio econômico-financeiro implica na ausência de causa para o enriquecimento, vedado pelo nosso ordenamento nos arts. 884 a 886 do Código Civil.

O princípio da vedação ao enriquecimento sem causa consagra uma das vertentes do princípio da igualdade, pois tem como principal objetivo garantir que a cada um seja atribuído o que é seu. Assim, para que se verifique sua violação é necessária a presença de três pressupostos: o enriquecimento, obtido à custa de outrem, sem que se apresente causa jurídica que o legitime. ${ }^{151}$

Em se tratando do negócio jurídico de crédito, os dois primeiros pressupostos não apresentam nenhuma controvérsia, e dizem respeito a vantagem patrimonial experimentada em detrimento de outrem, seja pelo tomador, seja pelo concedente. É o terceiro pressuposto, todavia, que realiza o conteúdo do princípio em análise.

A causa nada mais é que o fundamento necessário para que o deslocamento patrimonial se dê em consonância a preservação da propriedade tal como distribuída pelo ordenamento jurídico. Quer se dizer com isso que a causa localiza-se no entrelaçamento entre o mundo dos fatos e o ordenamento jurídico, consagrando uma medida de atribuição jurídica admissível em uma determinada relação. ${ }^{152}$

${ }^{151}$ São distintas as teorias acerca do enriquecimento sem causa, que o qualificam ora como uma vertente do valor moral, ou jurídico, ora como fonte de obrigação, ora como tutela do equilíbrio patrimonial. Apesar de não ser o objetivo do presente trabalho, apenas cumpre esclarecer que ao se referir a vedação ao enriquecimento sem causa quer se referir ao princípio geral de direito que determina a distribuição da propriedade sob o critério do equilíbrio econômico-financeiro.

${ }^{152}$ CAPUCHO, Fábio Jun. O enriquecimento sem causa no Código Civil Brasileiro. Ob. cit., p.103. 
O fundamento jurídico que torna legítima a cobrança de juros em negócio financeiro, localiza-se na medida da equivalência. Digo, o equilíbrio econômicofinanceiro, expresso pela equivalência entre situações de liquidez, configura a própria causa jurídica necessária para preservar a distribuição da propriedade conforme vislumbrada pelo ordenamento jurídico.

Desta forma, ainda que tipificado o crime de usura real com a obtenção de lucro patrimonial que exceda o quinto do valor corrente da prestação feita ou prometida, para que se verifique não basta apenas a prática de taxa de juros acima de $20 \%$ da prestação principal, mas que a esta se acumule o abuso de premente necessidade, inexperiência ou leviandade da outra parte (art. $4^{\circ}$, letra "b" da Lei $\mathrm{n}^{\circ} 1.521 / 1951$ ), e o desequilíbrio na relação de equivalência entre as duas situações de liquidez, sob o critério do equilíbrio econômico-financeiro do contrato e da vedação ao enriquecimento sem causa.

Observe que o critério do importe de um quinto do valor da prestação poderá restar prejudicado diante da necessidade em se praticar juros acima deste valor com a finalidade de restaurar o equilíbrio contratual.

Estas considerações esclarecem que a complexidade do tema exige uma análise minuciosa da relação contratual, em face da coletividade, das relações de mercado, e da participação do Estado na renda social, para que se possa fixar um limite à taxa de juros de maneira a resguardar o equilíbrio econômico-financeiro da relação jurídica. Por este motivo, veremos que não há como tratar deste limite em termos nominais, o que anularia a vertente dinâmica da composição das situações de liquidez, confrontando o princípio da vedação ao enriquecimento sem causa, seja em detrimento ao tomador, seja em detrimento ao concedente do crédito. 


\section{CAPÍTULO 4. JUROS E A PERSPECTIVA MACROJURÍDICA}

\subsection{JUROS NOMINAL E JUROS REAL}

Os juros nominais e reais dizem respeito ao poder de compra da moeda: serão reais aqueles que considerarem a instabilidade do poder de compra, e nominais aqueles que não o considerarem. Para tanto, algumas considerações acerca do valor da moeda são necessárias.

Num primeiro momento, à época da moeda conversível, o valor da moeda, era explicado, pela teoria metalista, em função do metal que fundamentava o lastro dado em depósito junto ao emissor. Com a determinação do curso forçado da moeda, seu valor passa a ser explicado, pela teoria quantitativa, em razão das oscilações no nível geral de preços e das disponibilidades monetárias, expressada na equação MV=PT (vide capítulo 2.1.).

Todavia, com a compreensão de que o valor é expressão duma relação de preferência, o valor da moeda passa a ser explicado em função da quantidade de bens e serviços cuja aquisição assegura nos mercados, sofrendo influência, portanto, não apenas dos elementos quantitativos, mas dos condicionamentos da liquidez, da propensão ao consumo, do nível de investimento e da capacidade social de produzir e poupar. ${ }^{153}$

José Tadeu De Chiara, ao falar em preço, esclarece que são dois os mecanismos que operam a adequação de seu valor: a revisão, referindo-se a seus elementos internos (relativos ao interesse da parte em exercitar a procura efetiva ou manter a liquidez) e, a indexação ou reajuste, referindo-se a seus elementos externos (relativos às vicissitudes do instrumento monetário). Por conseguinte, àquele cumpre estabelecer um novo patamar de equivalência, decorrente das alterações peculiares aos interesses das partes, enquanto que a este cumpre ajustar a expressão do preço decorrente do funcionamento estatal e da sociedade. $^{154}$

\footnotetext{
${ }^{153}$ CHIARA, José Tadeu de. A moeda e a ordem jurídica. Ob. cit., p. 43.

${ }^{154}$ Ibid., p. 110-135.
} 
Em se tratando da taxa de juros praticadas em negócio de crédito, o tempo é elemento determinante às condições de equivalência das situações de liquidez. Isto porque o valor da moeda, cuja expressão se dá em razão da quantidade de bens e serviços que assegura adquirir no mercado, sofre alterações no decurso temporal, de tal forma que expectativas em maior ou menor nível de instabilidade no poder de compra da moeda alteram situações de equivalência.

Se, para a formação da taxa de juros, for levada em conta apenas a situação de liquidez do momento da concessão do crédito, haverá o rompimento da relação de equivalência, deixando à sorte a perda da liquidez do credor ou devedor, diante dum acréscimo ou decréscimo no processo inflacionário. A fixação da taxa de juros em termos nominais colhe esta conseqüência, pois ignora a instabilidade do poder de compra do instrumento monetário.

Foi o que se observou com advento do Decreto-Lei 22.626/33, que fixou em termos nominais a taxa de juros em $12 \%$ ao ano, inviabilizando operações de crédito a médio e longo prazos, pois a expectativa de remuneração do capital sem levar em consideração as instabilidades do poder de compra da moeda impossibilitava a manutenção da equivalência das situações de liquidez durante todo o período do contrato.

Esclarece José Tadeu De Chiara ${ }^{155}$ que, diante do nominalismo da taxa de juros, foram criados mecanismos para viabilizar o negócio de crédito a médio e longo prazo de forma a superar os limites da lei da usura. Num primeiro momento, as instituições financeiras passaram a ampliar tarifas de serviços para compensar a perda da liquidez, o que apenas viabilizou negócios de crédito a curto prazo.

Num segundo momento, foram criadas as sociedades de crédito e os bancos de investimento, com a realização de contratos de sociedade em conta de participação com intermediário financeiro e os depositantes e com o intermediário financeiro e os tomadores. Naquela, o sócio ostensivo (intermediário financeiro) obrigava-se a remunerar, em taxa superior a lei da usura, os recursos monetários captados pelos depositantes, que apareciam como sócios ocultos e, nesta, o sócio oculto (intermediário financeiro) aplicava os recursos dos depositantes em financiamento a prazos longos em direção aos tomadores, que 
apareciam como sócios ostensivos, comprometidos a remunerar, em taxa superior a lei da usura, os recursos monetários tomados em empréstimo.

Ocorre que estas remunerações eram pagas a título de lucro da sociedade, sendo alvo de tributação pelo imposto de renda, inviabilizando as remunerações, o que fez, num terceiro momento, surgir a modalidade fundamentada no aceite cambial, e operacionalizado pelo sistema de ágio e deságio. O tomador sacava letras de câmbio contra o concedente do crédito, que por sua vez lançava seu aceite mediante uma comissão e colocava a letra de câmbio no mercado para negociação. Ao adquirente que passava a ser seu titular por endosso, favorecia o deságio da aquisição da letra em relação ao valor nela contido, e os recursos eram entregues ao tomador.

Esta limitação em termos nominais foi superada com o advento da Lei $n^{\circ} 4.595$ que, pela primeira vez, levou em consideração a variação do poder de compra da moeda, atribuindo competência ao Conselho Monetário Nacional limitar taxa de juros em negócio financeiro.

Disse-se que a taxa de juros se perfaz pelo interesse da coletividade (que no âmbito individual traduz o sentimento de egoísmo que orienta a opção de buscar da melhor forma a satisfação de suas necessidades em condições vantajosas), pelas relações de mercado (em função das disponibilidades monetárias, da preferência pela liquidez e da eficiência marginal do capital), pela participação do Estado na renda social e, pelo tempo (devendo assegurar o equivalente enquanto perdurar o negócio de crédito).

Todos estes elementos, adicionado dos diferenciais de risco, prazo, garantias e atributos peculiares a cada negócio, devem compor a formação da taxa de juros, a ser praticada num patamar que assegure a relação de equivalência entre as situações de liquidez.

José Tadeu De Chiara ${ }^{156}$ exemplifica que a modalidade de contratação de juros que reflete esta relação de equilíbrio em termos de situação de liquidez se dá com a Taxa Libor, praticada no mercado internacional. ${ }^{157}$

${ }^{156}$ Ibid., p. 143.

${ }^{157}$ A "London Interbank Offered Rate", publicada diariamente pela "British Bankers' Association", é a taxa média praticada para depósitos interbancários oferecida por oito bancos escolhidos de um total de 
No Brasil, como tentativa para se adotar solução semelhante, a despeito dos juros praticados pelas instituições financeiras já estarem liberados da lei da usura, a Resolução 1.143 de 26.06.1986 do Banco Central viria permitir contratações a taxas de juros flutuantes a partir de percentuais expressados na taxa ponderada praticada pelas instituições bancárias.

Em 1991, a taxa referencial de juros (TR) seria criada com o advento da Lei 8.177, calculada pelo Bacen a partir das taxas praticadas pelas trinta maiores instituições financeiras do País, assim consideradas em função do volume de captação efetuado por meio de certificados e recibos de depósito bancário (CDB/RDB), com prazo de 30 a 35 dias corridos, inclusive, e remunerados a taxas prefixadas (Resolução 2.809/2.000 do Conselho Monetário Nacional).

Com efeito, a contratação a taxa de juros flutuantes foi o instrumento utilizado como substitutivo ao mecanismo de indexação, o que fica evidenciado com o entendimento consagrado pela Súmula 295 do Superior Tribunal de Justiça ${ }^{158}$ que reconhecia a TR como indexador válido, desde que pactuada.

A indexação, ou reajuste, opera nos elementos externos à relação de direito que compõe o preço, ou seja, decorre das vicissitudes do instrumento monetário e se consubstancia na adequação do valor nominal da moeda, de tempo em tempo, por uma dada metodologia. Para a adequação do preço, entretanto, coexistem inúmeras metodologias, o que sugere que a eleição de uma delas como critério compromete-se com os interesses daquele que a escolheu.

Este mecanismo de indexação, num primeiro momento, permitiu que o Estado captasse recursos, na medida em que seus títulos pudessem ser negociados sem a perda do poder de compra da moeda. Contudo, num segundo momento, com a discrepância da metodologia de indexação em diferentes atividades, deparou-se com um desequilíbrio nas relações jurídicas e um comprometimento no padrão de valor da moeda. Para superar esta

dezesseis, com base em critérios de volume e risco, como: reputação, escala de atividade no mercado de Londres, competência na área de atuação, em atenção à operação de crédito. Disponível em: www.bba.org.uk, acessado em 20/12/2008.

${ }^{158}$ Súmula 295 STJ: "A Taxa Referencial (TR) é indexador válido para contratos posteriores à Lei $n$. 8.177/91, desde que pactuada." 
distorção, socorreram-se a taxa de juros, como tentativa em se manter o equilíbrio das relações contratuais. ${ }^{159}$

Todavia, a TR, como taxa de juros, expressa a situação de liquidez, e não a instabilidade no poder de compra da moeda, por este motivo é que é possível que uma taxa referencial de juros situe-se acima ou abaixo da inflação. Não demorou para que este entendimento fosse consagrado, diante da impropriedade em se utilizar taxa de juros como índice de correção monetária. É de valiosa lição o voto do Min. Relator Moreira Alves, em julgamento da ADIn 493-DF, cuja discussão tinha por objeto a constitucionalidade acerca da Taxa Referencial como índice de correção monetária, nos termos da Lei n 8.177/91:

"Com efeito, o índice de correção monetária é um número-índice que traduz, o mais aproximadamente possível, a perda do valor de troca da moeda, mediante a comparação, entre os extremos de determinado período, da variação do preço de certos bens (mercadorias, serviços, salários, etc.), para a revisão do pagamento das obrigações que deverá ser feito na medida dessa variação. Quando essa revisão é convencionada pelas partes temos clausula de escala móvel, também denominada cláusula de númeroindice, que ARNOLD WALD (...) define como "aquela que estabelece uma revisão, preconvencionada pelas partes, dos pagamentos que deverão ser feitos de acordo com as variações do preço de determinadas mercadorias ou serviços ou do índice geral do custo de vida ou dos salários". É pois, um índice que se destina a determinar o valor de troca da moeda, e que, por isso mesmo, só pode ser calculado com base em fatores econômicos exclusivamente ligados a esse valor. Por isso, é um índice neutro, que não admite, para seu cálculo, se levem em consideração fatores outros que não os acima referidos.

Ora, (...) não é isso o que ocorre com a Taxa Referencial (TR), que não é o índice de determinação do valor de troca da moeda, mas, ao contrario, índice que exprime a taxa média ponderada do custo de captação da moeda por entidades financeiras para sua posterior aplicação por estas. A variação dos valores das taxas desse custo prefixados por essas entidades decorre de fatores econômicos vários, inclusive peculiares a cada uma delas (assim, suas necessidades de liquidez) ou comum a todas (como, por exemplo, a concorrência com outras fontes de captação de dinheiro, a política de juros adotada pelo Banco

${ }^{159}$ CHIARA, José Tadeu de. A moeda e a ordem jurídica. Ob. cit. 
Central, a maior ou menor oferta de moeda), e fatores esses que nada tem a ver com o valor de troca da moeda, mas, sim, - o que e diverso-, com o custo da captação desta. $\mathrm{Na}$ formação desse custo não entra sequer a desvalorização da moeda (sua perda de valor de troca), que é a já ocorrida, mas - o que é expectativa com os riscos de um verdadeiro jogo - a previsão da desvalorização da moeda que poderá ocorrer. É, portanto, absolutamente falso, dizer-se que tendo o Conselho Monetário Nacional escolhido, na alternativa admitida pela Lei n. $8.177 / 91$ (depósitos a prazo fixo ou títulos públicos federais, estaduais ou municipais), a primeira, e havendo ele prefixado uma taxa de expurgo único (2\% a titulo de juros - que varia de banco para banco sem que o Conselho tenha elementos para individualizá-lo para efeitos desse cálculo - e de tributos), que o restante seja apenas decorrente de expectativa de desvalorização da moeda. E tanto assim é que, em período de relativa estabilidade monetária, essas taxas aumentam ou diminuem, não evidentemente em razão tão só da expectativa de mínima desvalorização da moeda, mas sim, da lei da oferta e da procura, que rege, também, o custo da captação do dinheiro." E conclui "Não é, pois, a Taxa Referencial índice de correção monetária (...) Assim sendo, são inconstitucionais, por ofensa ao disposto no artigo $5^{\circ}$, inciso XXXVI, da Constituição Federal, os artigos 18, caput, e $\$ \S$ $1^{\circ}$ e $4^{\circ} ; 20 ; 21$ e parágrafo único; e 23, todos da Lei $n^{\circ}$ 8.177 de $1^{\circ}$ de março de 1991, cujos dispositivos correspondentes a estes, perdem a eficácia desde sua edição (art. 62, parágrafo único da Constituição Federal) por se ter tornado sem efeito, "ex tunc", sua conversão em virtude da presente declaração de inconstitucionalidade."

Esclarece José Tadeu De Chiara ${ }^{160}$ que, com esse sistema, quando se falava em correção monetária, o resultado nominal decorrente do indexador aplicado sobre o patrimônio da pessoa jurídica era considerado lucro inflacionário, constituindo fato gerador para a cobrança de tributo. Desta forma, ao lado da TR, seria necessário utilizar um parâmetro que indicasse o acréscimo ou decréscimo real no patrimônio da sociedade, justificando o lucro e, por conseguinte, a tributação. Este parâmetro haveria de ser fixado por força da Medida Provisória $n^{\circ} 684$, de 31.10.94, hodiernamente consolidada com a Lei $\mathrm{n}^{\circ}$ 9.365/1996, com a criação da taxa de juros de longo prazo (TJLP), fixada pelo Conselho Monetário Nacional, com base em critérios de meta de inflação e prêmio de risco, associando o patrimônio da pessoa jurídica com o funcionamento do mercado, 
Com a promulgação da Constituição Federal de 1988, a discussão acerca do conceito de juros reais e nominais se impôs. O julgamento da ADIn 4-7/DF foi no sentido de que, inexistindo tal definição no ordenamento jurídico, deverá a lei complementar do Sistema Financeiro Nacional fazê-lo. ${ }^{161}$

Contudo, a despeito do conceito de juros reais não estar expresso no direito positivo, certo é que o ordenamento jurídico lança mão das noções necessárias para compreensão de seu conteúdo. Quer se dizer com isso que os princípios do equilíbrio econômico-financeiro do contrato e da vedação ao enriquecimento sem causa são suficientes para determinar que se assegure a equivalência das situações de liquidez, enquanto perdurar o contrato. Na medida em que se fixa a taxa de juros em termos nominais, não apenas há um recrudescimento nas políticas de moeda e crédito, mas há um comprometimento com o equilíbrio da relação contratual, impedindo que o juro resguarde a equivalência entre as situações de liquidez. Por este motivo é que a fixação da taxa de juros em termos nominais confronta-se com o ordenamento jurídico.

Com a consolidação deste entendimento, um importante avanço se observaria na legislação, com a previsão do art. 406 do Código Civil:

"Art. 406. Quando os juros moratórios não forem convencionados, ou o forem sem taxa estipulada, ou quando provierem de determinação da lei, serão fixados segundo a

${ }^{161 ، O}$ que são taxas de juros reais? O legislador constituinte não o disse, desde logo. Apenas referiu-se a alguns elementos que devem ser considerados, e descontados como despesas financeiras à efetivação do crédito. E isso é tudo? Não. Num país de inflação galopante e sem possibilidade visível de controle, a curto prazo, onde os índices de contagem inflacionária pululam, variando desde a OTN comum, passando pela fiscal e pelo dólar no câmbio oficial até desaguar nas altas astronômicas do ouro e do dólar no mercado paralelo, seria difícil às empresas financeiras e às próprias autoridades monetárias do Governo calcularem os juros reais, a serem cobrados nas operações do gênero. As taxas reais calculadas apenas sob os parâmetros estabelecidos pelo parágrafo constitucional, por não espelharem a realidade do mercado creditício, levarão, por certo, ao retraimento dos operadores, pois os juros reais constitucionais não estarão remunerando o capital, na satisfação dos lucros, numa economia de livre concorrência, e assim poderão tornar inviável o negócio do investidor, e este se retrair, em prejuízo da economia nacional, como um todo.14- A prudência recomenda uma definição legal dos juros reais, como quer o legislador constituinte e a técnica legislativa a indica. O parágrafo, sendo atrelado ao artigo, não tendo vida autônoma, e havendo o "caput" feito depender de lei complementar a regulamentação do sistema financeiro nacional, aquela lei é que vai dar operacionalidade a toda estrutura do sistema, inclusive definir juros reais, "de forma a promover o desenvolvimento equilibrado do País e a servir aos interesses da coletividade. 15- Assim sendo, como o legislador constituinte deferiu a legislador ordinário o poder regulamentador do sistema financeiro nacional, cabe a este explicitar o texto da Constituição para sua correta execução. Como o art. 192, no seu $\S 3$, não exaure o conceito de juros reais, a lei complementar, que regulará o Sistema Financeiro Nacional, deve fazê-lo." Supremo Tribunal Federal, ADIn. 4-7/DF, voto do Relator Ministro Min. Sydnei Sanches. 
taxa que estiver em vigor para a mora do pagamento de impostos devidos à Fazenda Nacional.”

A fixação dos juros moratórios legais segundo a taxa SELIC atribuiu a vertente dinâmica necessária para aproximar-se da noção de equivalência entre as situações de liquidez.

Assim, restou consagrado na legislação a necessidade em se considerar, na composição das taxas de juros, as instabilidades do poder de compra da moeda, bem como os elementos que orientam sua formação em razão do interesse da coletividade, das relações de mercado e da participação do Estado. 


\subsection{TAXA BÁSICA DE JUROS E AS PERDAS E DANOS NAS OBRIGAÇÕES EM DINHEIRO}

A despeito de formalmente instituída apenas em 1979, a origem da SELIC fundamenta-se na criação do mercado aberto no Brasil. Àquela época, o Tesouro Nacional emitia títulos da dívida pública, e os encaminhava para o Banco Central, que informava às sociedades corretoras (dealers) a quantidade destes títulos a certa taxa de juros que seria ofertada ao público. As dealers, por sua vez, coletavam as propostas de compra do sistema financeiro e repassavam ao Banco Central.

Apenas as instituições financeiras que mantivessem contas de reservas bancárias junto ao Banco Central poderiam participar deste leilão. Estas operações eram liquidadas mediante lançamentos de débito e crédito junto a estas contas de reservas, com a transferência de recursos para o Banco Central.

Estas operações de crédito eram feitas com cláusulas de recompra, de maneira que a instituição financeira que comprasse os títulos da dívida pública, apenas o detinha pelo tempo avençado para a recompra deste mesmo título pelo Banco Central, normalmente de 24 horas, motivo pelo qual são chamadas operações de overnight. Esta instituição, antes da recompra do título, poderia agir como representando de outras que não mantivessem junto ao Banco Central as contas de reservas bancárias, ou seja, poderia ofertar ao público não bancário os títulos públicos que adquiria. ${ }^{162}$

Assim, assegurando a detenção destes títulos, as instituições financeiras passavam a vendê-los em troca de uma nota e, com a ausência de um maior controle nestas operações, se permitiu que algumas instituições negociassem esses títulos sequer sem mantê-los em custódia no Bacen.

Desta forma e, com o crescimento do volume destas operações, que se operacionalizavam de forma física e na modalidade ao portador, foi necessária a criação de uma central de custódia que viabilizasse estas negociações com mais segurança e transparência, culminando no Sistema Especial de Liquidação e Custódia - SELIC.

${ }^{162}$ BACHA, 2004. 
A SELIC é o sistema informatizado de registro de depósito dos títulos públicos emitidos eletronicamente pelo Tesouro Nacional e pelo Banco Central do Brasil, destinado a processar a emissão, resgate, liquidação e custódia referente a estes títulos. ${ }^{163}$

Foi criada, portanto, em princípio, como medida de variação das taxas praticadas nestas operações do Sistema Especial de Liquidação e Custódia. É a média, portanto, destas operações de overnight, acumuladas dentro do prazo de um mês, que compõe a taxa SELIC.

Com o advento da Resolução n. 1.124, de 15 de junho de 1986 do Banco Central, a taxa média ajustada dos financiamentos apurados no Sistema Especial de Liquidação e de Custódia (SELIC) passaria a ser utilizada como rendimento para as Letras do Banco Central do Brasil, calculado sobre o valor nominal e pago no resgate. ${ }^{164}$

Esta determinação é consequiência da necessidade em se fixar as taxas de juros em parâmetros atrativos, para viabilizar o sistema de open-market, no qual os títulos públicos são negociados com o objetivo de controlar a moeda e o crédito (art. 164, $\S 2^{\circ}$ da Constituição Federal), e de financiar a dívida pública federal (vide capítulo 4.4.).

Diz o art. $2^{\circ}$, Parágrafo $1^{\circ}$ da Circular $n^{\circ} 2.900$ de 24.06.1999 do Bacen que a SELIC é "a taxa média ajustada dos financiamentos diários apurados no Sistema Especial de Liquidação e de Custódia (SELIC) para títulos federais"

Taxa SELIC, portanto, é a taxa de juros que reflete a expectativa de renda do capital para os empréstimos bancários, praticada no mercado que tenha como lastro títulos públicos federais negociados no Sistema Especial de Liquidação e Custódia. A metodologia da taxa SELIC é calculada de acordo com a seguinte fórmula ${ }^{165}$ :

${ }^{163}$ Circular n ${ }^{\circ} 2.727$ de 14.11.1996 do Banco Central do Brasil.

164“ O BANCO CENTRAL DO BRASIL, na forma do art. 9. da Lei n. 4.595, de 31.12.64, torna público que o CONSELHO MONETÁRIO NACIONAL, em sessão realizada nesta data, tendo em vista o disposto no inciso $V$ do art. 11 da mencionada Lei, R E S O L V E U:

I- Autorizar o Banco Central do Brasil a emitir títulos de sua responsabilidade, para fins de política monetária, com as seguintes características:

a) denominação: LETRA DO BANCO CENTRAL DO BRASIL;

f) rendimento: definido pela taxa média ajustada dos financiamentos apurados no Sistema Especial de Liquidação e de Custódia (SELIC) para títulos federais, divulgada pelo Banco Central do Brasil, calculado sobre o valor nominal e pago no resgate do título;"

${ }^{165}$ Circular no 2.761de 18.06.1997. 


\section{$\left.\left[\left(\frac{\left.\sum_{j=1}^{n} L j . V\right]}{\sum^{n}(V)}\right)^{252}-1\right) \times 100\right] \%$ ao ano $\sum_{j=1}^{n} v$}

Onde:

Lj: fator diário correspondente à taxa da j-ésima operação;

$\mathrm{Vj}$ : valor financeiro correspondente à taxa da j-ésima operação;

n: número de operações que compõem a amostra.

Do exposto se colhem imediatamente duas conseqüências: a taxa SELIC tem natureza de juros remuneratórios, pois desempenha a função de remunerar o capital, refletindo as condições de liquidez do mercado, bem como é fixada em termos reais, tendo em vista levar em consideração a instabilidade do poder de compra da moeda.

A vertente dinâmica consagrada pela taxa SELIC que revela a influência que sofre, em sua composição, por elementos de alteração de preço na economia, elucidam que, a despeito de não se confundir com o mecanismo de correção monetária, traz em seu bojo mecanismos de neutralização dos efeitos inflacionários, evidenciado com a metodologia de seu cálculo e sua operacionalização, existindo manifestação do próprio Banco Central do Brasil nesta direção:

"Do exposto podemos concluir que a taxa SELIC se origina de taxas de juros efetivamente observadas no mercado (...) Como todas as taxas de juros nominais, por outro lado, a taxa SELIC pode ser decomposta "ex post", em duas parcelas: taxa de juros reais e taxa de inflação no período considerado. A taxa SELIC, acumulada para determinados períodos de tempo, correlaciona-se positivamente com a taxa de inflação apurada "ex post". ${ }^{166}$

Ocorre que reza o art. 404 do Código Civil que, nas obrigações de pagamento em dinheiro, dar-se-á o pagamento com atualização monetária segundo índices oficiais regularmente estabelecidos, abrangendo além, juros, sem prejuízo da pena convencional.

\footnotetext{
${ }^{166}$ Comentários em Selic: mercado de títulos públicos, disponível em www.bcb.gov.br, acessado em 03/05/2008.
} 
A combinação, portanto, dos juros legais devidos por força do art. 406 do mesmo Codex, fixados segundo a taxa que estiver em vigor para a mora do pagamento de impostos devidos à Fazenda Nacional, qual seja, a Taxa SELIC, com atualização monetária configuraria bis in idem, visto esta já abranger em sua composição a neutralização da instabilidade do poder de compra da moeda.

Para se descobrir, portanto, a taxa de juros reais da SELIC é necessário que se faça o abatimento da taxa de inflação num período considerado (Juros reais = SELIC - IGPDI), de maneira que, para o cálculo das perdas e danos apenas deve ser considerado correção monetária e juros reais, ou juros nominais segundo a Taxa SELIC, dispensando-se a atualização monetária.

Ainda, cumpre considerar que estas taxas de juros não sofrem influência do risco do tomador de recursos financeiros nas operações compromissadas, isto porque o Estado goza de posição diferenciada nas relações jurídicas das quais faz parte. Por este motivo, a taxa SELIC, como expressão de uma taxa básica de juros que reflete a expectativa de renda do capital para os empréstimos bancários, com base na remuneração dos títulos públicos, servirá como referência para as demais taxas praticadas no mercado.

Assim, a taxa básica de juros sinaliza ao banco a eficiência do capital, ou seja, o custo de oportunidade que acrescido do custo de produção (neste caso custos operacionais de viabilização de operações de crédito) serão responsáveis por compor as taxas praticadas no mercado. Neste sentido:

"a TAXA DE JUROS BÁSICA representa o custo de oportunidade do BANCO, posto aqui pela TAXA DE JUROS BÁSICA adicionada de custos operacionais, risco e lucro. A TAXA DE JUROS BÁSICA, ou seja, aquela que o Governo paga nos seus títulos, representa o preço do capital para o BANCO.”... "Isso demonstra que as demais taxas praticadas no mercado são uma derivação desta última. Por sua vez, o SPREAD BANCÁRIO reflete o custo operacional dos agentes financeiros, seu lucro e seu risco (taxa média de inadimplência). Ou seja, o SPREAD BANCÁRIO constitui-se na diferença entre as taxas de empréstimos praticadas pelos BANCOS ou agentes financeiros junto aos tomadores de crédito MUTUÁRIOS, por exemplo) e a taxa de captação, que é a taxa à qual os BANCOS tomam recursos. O SPREAD BANCÁRIO visa não só cobrir os custos das operações 
financeiras e, portanto, as despesas relativas à atividade de intermediação financeira, mas também proporcionar uma margem líquida para o intermediário financeiro.

Vários fatores podem levar a um SPREAD BANCÁRIO elevado. Na TAXA DE JUROS cobrada, o BANCO contabiliza:

(a) prestações atrasadas;

(b) inadimplência;

(c) risco de crédito em função do mercado e da conjuntura econômica;

(d) cunha fiscal; $e$

(e) a própria expectativa de inflação.

Em estudo de dezembro de 2005 sobre a composição do SPREAD BANCÁRIO no Brasil, a FIPECAFI(32) mostrou a seguinte distribuição percentual:

1)Inadimplência - 13\%

2)Despesas com pessoal - $10 \%$

3)Despesas estruturais - $24 \%$

4)Tributos - 08\%

5)Custo de captação (juros aos aplicadores) - $36 \%$

6)Lucro líquido - 09\%

Assumindo que a TAXA DE JUROS dos financiamentos é determinada pela SELIC, adicionado um SPREAD BANCÁRIO, tem-se que:

$T J M=S E L I C+$ SPREAD BANCÁRIO

Onde:

TJM = Taxa de juros de financiamento ao mutuário"

Tem-se, assim, que parcela significativa dos juros é determinada através da TAXA DE JUROS BÁSICA, estabelecida pelo COPOM.

Por isso, os juros não podem ser fixados de forma independente da POLÍTICA MONETÁRIA do País." 167

Estas considerações permitem constatar que a adoção da Taxa SELIC como parâmetro de juros legais, com fulcro no art. 406 do Código Civil, consagrou a relevância em se garantir a vertente dinâmica das situações de liquidez, a despeito de, por si só, não ser suficiente para assegurar a relação de equivalência entre situações de liquidez, que se completa com a observância aos princípios de equilíbrio econômico-financeiro e da vedação ao enriquecimento sem causa. 


\subsection{A COBRANÇA DO CRÉDITO TRIBUTÁRIO EM FACE DA TAXA BÁSICA DE JUROS}

Em matéria tributária, a discussão que se impõe diz respeito ao mandamento previsto no parágrafo $1^{\circ}$ do art. 161 do Código Tributário Nacional e a possibilidade de utilização da Taxa SELIC a título de juros moratórios na cobrança dos créditos tributários.

O referido dispositivo legal determina que o crédito não integralmente pago no vencimento é acrescido de juros de mora à taxa de um por cento ao mês, se a lei não dispuser de modo diverso.

Com o advento da Lei ${ }^{\circ} 8.981$ de 20.01.1995, que alterou a legislação tributária, houve a fixação de um novo parâmetro para os juros de mora decorrente dos créditos tributários, qual seja, a equivalência à taxa média mensal de captação do Tesouro Nacional relativa à Dívida Mobiliária Federal Interna ${ }^{168}$ que, posteriormente, com a Lei no 9.065 de 20.01.1995 seria alterado pela equivalência à taxa referencial do Sistema Especial de Liquidação e de Custódia - SELIC para títulos federais, acumulada mensalmente ${ }^{169}$.

Diante de tais alterações legislativas, sob o fundamento da Taxa SELIC não haver sido criada para fins tributários, inúmeras manifestações insurgiram questionando a constitucionalidade da lei que a fixava como parâmetro para cobrança de juros moratórios nos créditos tributários.

Argumentam, pois, que em matéria de tributação, os critérios para aferição do crédito há de ser definido com clareza pela lei, sem que se possa aplicar um elemento de remuneração de título público em tributo, sob pena de se criar a figura de tributo rentável e,

168“'Art. 84. Os tributos e contribuições sociais arrecadados pela Secretaria da Receita Federal, cujos fatos geradores vierem a ocorrer a partir de $1^{\circ}$ de janeiro de 1995, não pagos nos prazos previstos na legislação tributária serão acrescidos de:

I - juros de mora, equivalentes à taxa média mensal de captação do Tesouro Nacional relativa à Dívida Mobiliária Federal Interna;"

169“Art. 13. A partir de $1^{\circ}$ de abril de 1995, os juros de que tratam a alínea c do parágrafo único do art. 14 da Lei $n^{\circ} 8.847$, de 28 de janeiro de 1994, com a redação dada pelo art. $6^{\circ}$ da Lei $n^{\circ} 8.850$, de 28 de janeiro de 1994, e pelo art. 90 da Lei $n^{\circ}$ 8.981, de 1995, o art. 84, inciso I, e o art. 91, parágrafo único, alínea a.2, da Lei $n^{\circ}$ 8.981, de 1995, serão equivalentes à taxa referencial do Sistema Especial de Liquidação e de Custódia - SELIC para títulos federais, acumulada mensalmente." 
além, permitir sua majoração sem lei anterior que o estabeleça, o que confrontaria o princípio da anterioridade tributária (art. 150, I da Constituição Federal).

Sustentam ainda o ferimento ao princípio da indelegabilidade de competência tributária, tendo em vista o quantum debeatur do crédito tributário ser determinado em razão da taxa SELIC, cuja fixação se dá pelo Banco Central do Brasil, que tem competência financeira atribuída pela Lei $\mathrm{n}^{\circ}$ 4.595, mas não tributária. Outrossim, sustentam o ferimento ao principio da legalidade, uma vez que a composição da taxa SELIC se sujeita a dinamicidade do mercado, atrelado às regras da oferta e da procura, incompatível com a restrita legalidade a que se submete a matéria tributária.

Ainda, alegam que a fixação de novos parâmetros para os juros moratórios decorrentes do crédito tributário haveria de observar o limite determinado pelo Código Tributário Nacional de um por cento ao mês, apenas podendo ser extrapolado se fixado por lei complementar posterior e não por lei ordinária, como é a natureza da Lei $n^{\circ} 9.065$ de 20.01.1995.

Certo é que a matéria tributária, tendo em vista a natureza de sua atividade, conforma-se a uma combinação rígida de regras e princípios, dos quais importam tratar os princípios da legalidade, da anterioridade, e da indelegabilidade da competência tributária.

Pelo princípio da legalidade temos que é vedada a criação ou majoração de tributos sem lei ${ }^{170}$ que o estabeleça (art. 150 da Constituição Federal), que deverá descrever o fato gerador tributável, os sujeitos ativo e passivo, os elementos necessários ao conhecimento do valor devido, as penalidades por seu descumprimento, bem como suas causas de exclusão, extinção e suspensão.

Quando se fala em elementos necessários para conhecimento do quantum devido, quer se tratar da obrigação principal e, portanto, da base de cálculo e da alíquota que constituem remuneração. Quando se fala em penalidade, quer se tratar da obrigação acessória e, portanto, dos encargos moratórios que constituem recomposição.

\footnotetext{
${ }^{170}$ Trata-se em regra de lei ordinária, comportando exceções no tocante aos tributos federais instituídos por lei complementar (arts. 148, 153, VII, 154, I e 195, §4º da Constituição Federal), dos impostos federais que podem ter sua alíquota majorada pelo Poder Executivo Federal mediante Decreto (arts. $153, \S 1^{\circ}, 155, \S 4^{\circ}, \mathrm{IV}, \mathrm{c}, 177, \S 4^{\circ}, \mathrm{I}, \mathrm{b}$, da Constituição Federal), e dos tributos que podem ser instituídos ou majorados por medida provisória (art. $62, \S 2^{\circ}$, da Constituição Federal).
} 
Observe-se que a taxa SELIC, como a expressão da taxa média ajustada dos financiamentos diários apurados no Sistema Especial de Liquidação e de Custódia para títulos federais, cobrada a título de juros moratórios decorrente do crédito tributário revela sua natureza punitiva e de frutos acessórios do capital principal, motivo pelo qual não representa acréscimo ao tributo, mas apenas compensação pelo inadimplemento.

Outrossim, ainda que se admita que a referida taxa situe-se no campo da obrigação principal - uma vez que em matéria tributária a obrigação acessória, pelo simples fato da sua inobservância, converte-se em obrigação principal relativamente à penalidade pecuniária (art. 113 do Código Tributário Nacional) - o simples fato da apuração da taxa SELIC se dar "ex post" não configura imprevisibilidade.

O Código Tributário prevê o acréscimo de juros de mora ao crédito não integralmente pago no vencimento, pelo parâmetro determinado na Lei $\mathrm{n}^{\circ} 9.065$ de 20.01.1995 de equivalência à taxa referencial do Sistema Especial de Liquidação e de Custódia - SELIC, acumulada mensalmente, de maneira que não há qualquer afronta a exigibilidade de previsão da penalidade pelo descumprimento da obrigação tributária.

A Taxa SELIC, ainda que composta por uma taxa de juros reais e neutralização do processo inflacionário, não compromete a exigência de critérios objetivos para aferição do importe devido do crédito tributário, uma vez que sua metodologia de cálculo é conhecida e não arbitrária.

Diante do exposto, resta contaminado inclusive o argumento de que a utilização da Taxa SELIC para créditos tributários afrontaria o principio da anterioridade. Sobre o princípio da anterioridade tributária é vedado aos entes federativos cobrar tributo no mesmo exercício financeiro ou, antes de decorridos noventa dias, sem que haja sido publicada a lei que os instituiu ou aumentou (art. 150, III "b” da Constituição Federal) ${ }^{171}$. Ressalta-se mais uma vez que o que contraria o referido princípio diz respeito a exigibilidade diante da ausência de previsão no lapso temporal determinado, e não a taxas cujo mecanismo de cálculo fundamenta-se em elementos posteriores a sua previsão. Entender o contrário, apenas porque a taxa SELIC assegura uma vertente dinâmica e, por conseguinte, sua expressão nominal não é conhecida antes do fato gerador, é restringir a

\footnotetext{
${ }^{171}$ São exceções a anterioridade anual: arts, 148, I, 150, §1 ${ }^{\circ}$, parte inicial, e 154 , II da Constituição Federal, e exceções a anterioridade nonagesimal: art. 150, $§ 1^{\circ}$, parte final da Constituição Federal.
} 
cobrança de encargos moratórios apenas em termos nominais ou em taxas pré-fixadas previstos na lei.

Ademais, quando a Lei $\mathrm{n}^{\circ} 4.595$ atribui ao Banco Central competência financeira, o autorizou a criar a taxa de juros SELIC, e não delegou competência tributária apenas em razão desta taxa ser utilizada como parâmetro de cálculo para juros moratórios decorrente de créditos tributários. Foi a própria Lei n ${ }^{\circ} 9.065$ de 20.01.1995, de natureza tributária, que determinou a utilização da Taxa SELIC como parâmetro de cálculo de juros de mora.

A Lei $n^{\circ} 9.065$ de 20.01.1995 não colhe qualquer inconstitucionalidade, porque o que determina o art. 146 da Constituição Federal é que a criação de normas gerais em matéria tributária há de ser feita mediante lei complementar, de maneira que matéria como juros poderá ser disposta mediante lei ordinária.

Ainda que houvesse dúvida sobre isto, o próprio art. 161, $\S 1^{\circ}$, do Código Tributário Nacional esclareceria, pois ao fixar a taxa de juros de mora no importe de um por cento ao mês, condiciona "se a lei não dispuser de modo diverso", evidenciando sua aplicação em caráter subsidiário. Para que se aplique, portanto, outra taxa de juros, apenas é necessário que exista previsão legal acerca do assunto, tendo o próprio Código Tributário autorizado que se fixasse por meio de lei ordinária. Se assim não o fosse, disporia de maneira diversa, como o fez em outras oportunidades. ${ }^{172}$

O art. 13 da Lei $n^{\circ} 9.065 / 1995$, referindo-se ao art. 84 da Lei $n^{\circ} 8.981 / 1995$, foi confirmado por outras normas: art. 39, $\S 4^{\circ}$, da Lei $n^{\circ} 9.250 / 1995$; art. 61, $\S 3^{\circ}$, da Lei $n^{\circ}$ 9.430/1996 e o art. 30 da Lei n. 10.522/2002, sem colher qualquer inconstitucionalidade.

Conclui-se, pois, pela possibilidade em se cobrar taxa básica de juros a título de juros moratórios decorrentes de crédito tributário, sem qualquer afronta aos princípios supra mencionados. ${ }^{173}$

\footnotetext{
${ }^{172}$ Art. 30: "Tributo é toda (...) instituída em lei"; Art. 9, I: "sem que a lei o estabeleça."; Art. 13, parágrafo único: "mediante lei especial"; Art. 114: "definida em lei como necessária e suficiente à sua ocorrência"; Art. 137, I: "conceituadas por lei”; art. 153: "A lei que concede moratória”; Art. 176: "sempre decorrente de lei que especifique as condições e requisitos exigidos".

${ }^{173}$ Superior Tribunal de Justiça, AI no REsp 215881 (1999/0045345-0 - 08/04/2002) .
} 


\subsection{JUROS COMO INSTRUMENTO DE POLÍTICA MONETÁRIA}

As primeiras normas regulamentadoras da atividade monetária referiam-se a adoção de sistemas que determinavam os limites da emissão de notas bancárias em relação aos encaixes metálicos que mantinham em seus cofres. Na Inglaterra, o banco público só estava permitido a emitir nota até o limite do encaixe metálico acrescido duma soma física (sistema de cobertura integral), na Alemanha, Bélgica, Itália, Holanda a relação entre emissão e encaixe era definida em lei (sistema de reserva proporcional), enquanto que na França, a emissão estava submetida à fixação de um teto máximo, sem guardar correspondência ao encaixe (sistema de teto). ${ }^{174}$

Com adoção do curso forçado ${ }^{175}$ e do curso legal ${ }^{176}$ da moeda, os bancos rapidamente perceberam que a quantidade de base monetária mantida em caixa estava diretamente ligada a quantidade de base monetária que poderiam disponibilizar em crédito, de maneira que, para proteger o depositante de eventuais insuficiências de fundos, foi necessário adotar um mecanismo de controle quantitativo fundamentado na exigência às reservas de caixa que os bancos deveriam manter junto às suas instituições para fazer jus à diferença de depósito e retirada da movimentação diária.

Nesta oportunidade, os mecanismos de controle tinham como finalidade apenas conter crises de insolvência e liquidez e atender eventuais disponibilidades de saques, das instituições que serviam como depositárias da renda social não consumida.

Num segundo momento, com a percepção que a atividade de intermediação financeira operava o efeito multiplicador da moeda, a partir dos depósitos bancários, foi criado um mecanismo necessário para manipular a base monetária sobre a qual se operacionalizava negócios de crédito: o depósito compulsório.

Este mecanismo constitui-se na determinação de que parte dos depósitos das instituições financeiras seja compulsoriamente depositada junto ao Banco Central. Com o

\footnotetext{
${ }^{174}$ HUGON, 1972, p. 40-44.

${ }^{175}$ Emissão da moeda escritural sem que haja prévio depósito correspondente.

${ }^{176}$ Determinação legal que proíbe a recusa da moeda na liberação de qualquer vínculo obrigacional constituído em pagamento.
} 
encaminhamento desta renda ao Banco Central. Assim, as instituições financeiras dispunham de uma menor quantidade de moeda para conceder em negócios de crédito, provocando uma redução da base sobre a qual recai o efeito multiplicador da moeda.

$\mathrm{Na}$ medida em que o crédito passa a ser percebido como o mecanismo pelo qual se antecipa a renda social e, que, numa economia monetária todos os fatores econômicos são remunerados por moeda, resta revelado que estas operações de crédito interferem no fluxo monetário e, conseqüentemente, no nível geral de preços, que se comportam da forma enunciada na expressão MV=PT.

O negócio de crédito, assim, é visto sob uma perspectiva de ordem pública, ou seja, pela possibilidade em se alterar os resultados da atividade econômica do Estado, em sua expressão monetária, ora ampliando o consumo, ora ampliando o investimento, e influenciando o nível geral de preços.

Esta constatação revelou a necessidade do negócio de crédito sujeitar-se a interferência estatal, não apenas com a finalidade de salvaguardar os particulares do efeito multiplicador da moeda, diante duma eventual crise de insolvência, mas além, para controlar nível de preços e instrumentar política econômica orientando fluxos de renda em direção ao consumo e investimento.

Cria-se assim a possibilidade ao Estado de comprar e vender títulos da dívida pública induzindo o funcionamento da atividade bancária. A negociação destes títulos age diretamente no aumento ou retração da moeda em circulação e, por conseguinte, no volume do crédito.

Estes títulos da dívida pública que são emitidos ficam guardados junto ao Banco Central, compondo seu ativo, com a finalidade de ser negociado. A instituição financeira que adquire o direito em relação ao título, o paga na conta de reserva bancária, e este título é mantido sob custódia.

O efeito direto da venda desses títulos públicos é a retirada de circulação da quantidade de base monetária correspondente ao valor dos títulos sobre os quais a instituição financeira adquiriu o direito, com a conseqüente redução na base sobre a qual se operam as concessões de crédito. O efeito da compra desses títulos se dá no sentido 
contrário, ou seja, aumenta-se a circulação monetária ao mesmo tempo em que aumentam as reservas das instituições financeiras que serão utilizadas nas operações de crédito. ${ }^{177}$

Quando se fala em mercado aberto e negociações de títulos da dívida pública, se está diante da situação peculiar em que o Estado concorre com os demais agentes econômicos, disputando parcelas da renda social não consumida. Ocorre que o Estado goza de posição diferenciada nas relações jurídicas das quais faz parte, em razão do princípio da indisponibilidade e supremacia do interesse público: não se sujeita a falência; não depende de atuação no mercado para ampliar receita; independe da concorrência do mercado. A relevância de sua participação como agente no mercado transparece em função da magnitude dos recursos que busca para suprir suas insuficiências de caixa, além disso, serve-se também de prazos diferenciados e garante a credibilidade e segurança necessárias para a contratação.

A decisão que a instituição financeira tem de tornar-se credora do Estado, digo, de optar utilizar a renda dada em depósito para subscrever títulos da dívida pública e não para instrumentar operações de crédito, é tomada não apenas por estas qualidades específicas, mas pela expectativa de renda do capital.

Se o comércio jurídico orienta-se em função do egoísmo, e a preferência pela liquidez em razão do motivo especulação, as instituições contratarão com o Estado na medida em que for mais vantajoso se tornar credor deste do que dos particulares. Esta vantagem é mensurável em função das taxas de juros.

Assim, se, em uma operação de open-market, o Banco Central oferta títulos a taxas de juros atraentes, as instituições financeiras optarão com a renda depositada subscrever títulos públicos, e não instrumentar operações de crédito, o que implicará numa retirada de parcela da renda de circulação, reduzindo, portanto, a liquidez e a base de ampliação da moeda. Se, pelo contrário, o Banco Central se depara com a necessidade de ampliação da base monetária, reduz a taxa de juros, direcionando o encaminhamento da poupança aos tomadores particulares de crédito, ou resgata os títulos junto ao público, aumentando a liquidez. Com efeito, verifica-se que o instrumento pelo qual se viabiliza este mecanismo de política monetária é o juro.

${ }^{177}$ HUGON, 1972, p. 122. 
Com o desenvolvimento destes mecanismos de controle numa perspectiva de ordem pública, a interferência do Estado na renda social poupada gera a percepção de que esta renda se configura uma fonte de receita ao Estado, permitindo que seja utilizada como mecanismo de financiamento do déficit público.

Esta consideração colhe relevante consequiência, pois implica considerar que não apenas o Banco Central é o órgão responsável por operacionalizar os instrumentos de política de crédito e moeda, no sentido de orientar a renda social, seja em direção ao consumo, seja em direção ao investimento, bem como revela a utilização de tais instrumentos para financiar insuficiência de recursos do Estado, retirando parcelas da poupança.

Desta forma, o déficit do Estado passa a ser financiado mediante três mecanismos: arrecadação tributária, emissão monetária e negociação de títulos da dívida pública. A principal limitação da arrecadação tributária como mecanismo de financiamento do Estado decorre de sua sazonalidade, uma vez que vai depender, exclusivamente, da ocorrência do fato gerador e, por conseguinte, da capacidade contributiva da sociedade. A limitação da emissão monetária, por sua vez, decorre das consequiências diretas que se colhe no âmbito da atividade econômica do Estado, com alterações no nível de preços. ${ }^{178}$

Esta percepção inicia-se em 1933, com a fixação dos juros em termos nominais, por força do Decreto ${ }^{\circ} 22.626$ (Lei da Usura), que vedava juros superiores ao dobro da taxa legal e, portanto, de $12 \%$ ao ano.

Com o público se valendo de mecanismos que assegurassem a prática de juros acima dos limites da lei da usura (vide capítulo 4.1.) e o Estado adstrito a seu teor, os intermediários financeiros passaram a obrigar-se com o Estado a taxas de $1 \%$ ao mês, e com o público a taxas reais. Este efeito gerou distorções no plano de todos os mecanismos de controle da moeda e do crédito, inviabilizando as operações de redesconto, de openmarket e até mesmo de arrecadação tributária.

No âmbito das operações de redesconto de liquidez, as taxas de juros fixadas em altos patamares desempenham a função de resguardar seu caráter de penalidade, desestimulando a insolvência. Entretanto, com taxas de juros fixadas em $1 \%$ ao mês, estas

\footnotetext{
${ }^{178}$ CHIARA, José Tadeu de. A moeda e a ordem jurídica. Ob cit.
} 
operações passaram a ser encaradas como verdadeiras fontes de subsídios às instituições financeiras que se socorriam junto ao Banco Central para adquirir liquidez. ${ }^{179}$

Outrossim, esta limitação da taxa de juros comprometeu a arrecadação tributária, uma vez que os juros moratórios decorrentes do crédito tributário não integralmente pago perderam seu caráter punitivo, bem como sequer seriam suficientes para compensar os gastos decorrentes da fiscalização destes créditos.

Finalmente, as operações de open-market como mecanismo de financiamento da estrutura do Estado foram inviabilizadas, em razão dos títulos públicos não poderem ser ofertados a taxas competitivas no mercado, aumentando a base da expansão monetária com o encaminhando da renda poupada e depositada junto às instituições financeiras em direção aos tomadores particulares.

Com dois, dos três mecanismos utilizados para financiamento do déficit público, comprometidos em razão da limitação nominal da taxa de juros, restou ao Estado lançar mão do único mecanismo disponível: a emissão monetária. Ocorre que uma vez que os preços se comportam em função das disponibilidades monetárias (vide capítulo 2.1.), o aumento na base monetária gerou consequiências na perda do poder aquisitivo da moeda e, por conseguinte, no aumento do nível geral de preços, o que acarretou uma tendência inflacionária.

Nesta época, a necessidade em se conter a emissão desenfreada da moeda a todo tempo se chocava com a necessidade em se obter recursos para financiamento da estrutura do Estado, de forma que em 1942 tentou se limitar estas emissões decretando-se que deveriam respeitar uma garantia de $25 \%$ em ouro e divisas (Decreto-lei $n^{\circ} 4.792$ ), com o posterior restabelecimento da emissão sem limite pelo Decreto-lei $\mathrm{n}^{\circ}$ 8.220.

A disposição constitucional que atribuía competência ao Congresso Nacional a emissão de papel-moeda (art. 65 da Constituição Federal de 1946) foi contornada pelo art.

${ }^{179} \mathrm{O}$ redesconto de liquidez, que ocorre quando um banco comercial se socorre junto ao Banco Central, emitindo títulos em troca de instrumento monetário, para evitar crises de insolvência e recuperar sua liquidez, quando praticado com alta taxa de juros servem como mecanismo para desestimular a insolvência, enquanto que o redesconto seletivo, que se dá pelo redesconto de títulos junto ao Banco Central, em razão de empréstimos concedidos pelos bancos comerciais a certas atividades previamente definidas pelo Banco Central, quando praticado com taxas de juros atrativas, direcionam o encaminhamento da poupança para as atividades que se pretenda desenvolver. BACHA, 2004, p. 80. 
48 do Código de Contabilidade que permitia ao governo autorizar as despesas orçamentárias excedentes "em caso de necessidade impreterível". O aumento no volume de emissões (circulavam cinco bilhões de cruzeiros, em 1939 e, mais de trinta e um bilhões de cruzeiros, em 1950) acarretou a aceleração da inflação até o golpe militar. ${ }^{180}$

Com a Revolução de 31 de março de 1964, uma nova política econômica foi delineada, com intuito de se corrigir as principais distorções no sistema de preços, disciplinar o controle do crédito, e estimular o crescimento da economia sem alta inflacionária.

A lei $\mathrm{n}^{\circ} 4.357$ de 16.07.1964 traria alterações significativas no controle do crédito e da moeda, ao criar os títulos públicos de longo prazo (Obrigações Reajustáveis do Tesouro Nacional - ORTN) e permitir sua correção monetária, segundo uma metodologia própria. Esta medida permitiu o resgate da credibilidade dos títulos públicos que passaram a se proteger contra as instabilidades do instrumento monetário, constituindo uma importante fonte de financiamento. Com a possibilidade de aplicação desta correção monetária também aos débitos fiscais, e um fomento na fiscalização, os níveis da arrecadação tributária se elevaram.

Todavia, seria com a promulgação da Lei n 4.595 de 31.12.1964 que as operações de crédito praticadas pelas instituições financeiras estariam a salvo da lei usura, podendo ser praticadas a taxa de juros limitadas pelo Conselho Monetário Nacional, segundo a atribuição de competência prevista no art. $4^{\circ}$, inciso IX. Os juros praticados em negócio financeiro passariam a ter regime jurídico distinto dos juros praticados em negócio mercantil.

O parágrafo $2^{\circ}$, do art. 49 desta lei mantinha a possibilidade do Estado financiar seu déficit público com a emissão monetária, pois permitia que o Banco Central, mediante autorização do Conselho Monetário Nacional, pudesse adquirir diretamente letras do Tesouro Nacional, com emissão de papel-moeda. Esta possibilidade perdurou até a promulgação da Constituição Federal de 1988, que por força de seu art. 164, parágrafo $1^{\circ}$, vedou ao Banco Central conceder, direta ou indiretamente, empréstimos ao Tesouro Nacional e a qualquer órgão ou entidade que não seja instituição financeira.

${ }^{180}$ HUGON, 1972, p. 165. 
O mecanismo de emissão de moeda para financiamento da estrutura do Estado foi substituído pelas operações de open-market, com atribuição de competência ao Banco Central para comprar e vender títulos públicos federais, conforme previsão no inciso XII do art. 10 da referida lei, ratificado pela Constituição Federal, em seu parágrafo $2^{\circ}$ do art. 164.

O mercado aberto iniciou-se com a introdução das Letras do Tesouro Nacional (LTN), cuja emissão, colocação e resgate eram realizados pelo Banco Central. Estas LTNs diferenciavam-se das Obrigações Reajustáveis do Tesouro Nacional por terem prazo inferior definido em função da inflação (Decreto-Lei n ${ }^{\circ} 2.376$ de 25.11.1987). ${ }^{181}$

Com a implantação da SELIC e a substituição da liquidação física das operações de compra e venda de títulos públicos por meio de lançamento de débitos e créditos nas reservas bancárias das instituições financeiras junto ao Banco Central, os títulos públicos passam a ser corrigidos em conformidade a esta taxa.

O atrativo estava na composição da SELIC, mensurada diariamente, consoante uma taxa de juros real adicionada à correção monetária. Isto significa dizer que, se a criação da ORTN serviu para resgatar a credibilidade do Estado como devedor, resguardando aqueles títulos públicos das instabilidades do poder de compra da moeda, a SELIC, por sua vez, conferiu aos títulos públicos a conformação da taxa de juros em patamares atraentes para atração do investidor, que se orienta pelos motivos de liquidez (vide capítulo 2.1.).

Na prática, a despeito dos juros praticados pelas instituições financeiras a salvo da lei da usura e, por conseguinte, na possibilidade em se utilizá-los como mecanismo de controle de política de crédito e moeda, o que se verificou foi que a partir deste momento, as taxas de juros passaram a ser manipuladas para financiar o déficit público.

Evidenciando a utilização das operações de open-market com a finalidade de financiar a estrutura do Estado, o Decreto $\mathrm{n}^{\mathrm{o}} 2.376$ de 25.11.1987 permitia ao Tesouro Nacional emitir títulos de sua responsabilidade (Letras Financeiras do Tesouro - LFT) atrelados à taxa SELIC, passando a dívida pública a ser rolada diariamente pelas operações de overnight.

181، “Art. $2^{\circ}$ As Letras do Tesouro Nacional instituídas por este decreto-lei poderão ser emitidas para cobertura de déficit orçamentário, bem assim para realização de operações de crédito por antecipação da receita, observados os limites fixados pelo Poder Legislativo." 
Com efeito, em abril de 2003, a SELIC chegou a representar, na Dívida Pública Mobiliária Federal Interna (DPMFi), 67,68\% de sua composição. Em outubro de 2008, a despeito desta relação ter caído para $36,26 \%$, ainda representa o fator de maior participação na composição da DPMFi. ${ }^{182}$

O Plano Real, ao implantar a atualização diária do padrão monetário (Unidade Real de Valor - URV instituída por força da Lei $\mathrm{n}^{\circ} 8.880$ de 27.05.1994) e ao eliminar a indexação (Lei $\mathrm{n}^{\circ} 10.192$ de 14.02.2001), gerou a possibilidade das transferências de valor se dar de forma praticamente estável, uma vez que o instrumento monetário acumulava as instabilidades diariamente, neutralizando a inflação na data da transferência.

Assim, a manipulação na taxa de juros que passa a substituir o sistema de indexação, aliada com a política cambial, faz com que o financiamento do déficit público deixe de ser operacionalizado em função da emissão de títulos públicos e passe a se dar em função da captação de capital estrangeiro. Por conseguinte, é a partir desta época que os juros passam a desempenhar diferentes funções:

"a taxa de juros passou a ter múltiplas funções após a implantação do Plano Real: estabilizar a inflação, equilibrar o Balanço de Pagamentos (mantendo a taxa de câmbio sobrevalorizada), induzir investidores internos a comprar títulos para financiar o déficit público, e reduzir o déficit comercial através do controle da demanda interna." 183

A taxa de câmbio, nos ensinamento de José Tadeu De Chiara, é fator de conversão de moeda que transita pelo nominalismo monetário, que não se confunde com índice ou sistema de indexação, cuja formação orienta-se, no âmbito interno: em razão do conjunto de dispêndios necessários para que os bens e serviços sejam produzidos e, no âmbito externo: em razão da alternativa de venda de produtos nacionais em concorrência com os produtos internacionais. ${ }^{184}$

\footnotetext{
${ }^{182}$ Em Relatório da Dívida Pública disponível em www.tesouro.fazenda.gov.br, acessado em $10 / 06 / 2008$.

${ }^{183}$ HARFUCH, Leila. Determinantes da Taxa de Juros Nominal e sua relação com a taxa de câmbio no Brasil no período de 1990 a 2006. Ob. cit., p. 20.

${ }^{184}$ CHIARA, José Tadeu de. A moeda e a ordem jurídica. Ob cit.
} 
Sustentam as teorias econômicas que um aumento na taxa de juros pode provocar um duplo efeito na taxa de câmbio, pois, se de um lado, o aumento na taxa de juros faz aumentar o fluxo de capitais estrangeiros no país, provocando a valorização da taxa de câmbio, por outro lado, este aumento no fluxo de capitais poderia provocar uma redução na credibilidade do Estado em honrar seus compromissos, o que faria com que a taxa de cambio desvalorizasse.

Certo é que, a despeito dos efeitos que provoca na taxa de câmbio, a manipulação da taxa de juros influencia a atração de investidor externo, uma vez que sinaliza a expectativa de renda do capital em relação ao conjunto dos demais países concorrentes, agindo também no controle da inflação. ${ }^{185}$

À época do Plano Real, em razão do processo de intensificação da abertura econômica e do aumento da taxa de juros serem insuficientes para conter a acelerada inflação que se estendeu ao longo dos anos (o que gerou a fixação da taxa de juros em patamares elevadíssimos), o câmbio foi adotado como instrumento para conter as instabilidades do poder de compra da moeda. Inicialmente, foi estabelecido um regime de bandas assimétricas, com estipulação apenas de um limite máximo de taxa de câmbio que, por conta dos investimentos estrangeiros, atraídos pela alta taxa de juros, provocaram sua substancial queda. Em março de 1995 haveria a estipulação também de um limite mínimo para evitar a desvalorização da taxa de câmbio. Todavia, o desequilíbrio nas contas do governo e a necessidade de financiar seu déficit forçaram a fixação da taxa básica de juros no patamar de 43,4\% em outubro de 1997. Algumas crises no cenário internacional e a fuga de capital estrangeiro do país culminaram na livre flutuação do câmbio, com sua subseqüiente desvalorização. ${ }^{186}$

Nesta conjuntura, com o advento do Decreto ${ }^{\circ} 3.088$ de 21.06.1999, a taxa básica de juros, divulgada pelo Banco Central do Brasil, passa a servir como instrumento para atendimento das metas fixadas em razão do novo regime de política monetária baseada em metas para inflação. Com esta nova sistemática, a taxa de juros passa a gerar algumas distorções no âmbito da política monetária.

\footnotetext{
${ }^{185}$ HARFUCH, Leila. Determinantes da Taxa de Juros Nominal e sua relação com a taxa de câmbio no Brasil no período de 1990 a 2006. Ob. cit.

${ }^{186}$ POLICANO, Rodrigo Mantovani. A sensibilidade da política monetária no Brasil: 1995-2005. Ob. cit.
} 
Este regime de metas para inflação funciona da seguinte forma: o Conselho Monetário Nacional, a quem compete formular as políticas monetárias (Lei n 4.595/1964) disciplina as metas da inflação e intervalo de tolerância tendo como índice de referência o IPCA $^{187}$ (Resolução 3.463 de 26 de junho de 2007 do Banco Central do Brasil). O Copom, por sua vez, analisa o Relatório da Inflação ${ }^{188}$, e define a meta da taxa SELIC $^{189}$ e seu eventual viés (Circular 3.297 do Banco Central do Brasil) ${ }^{190}$.

Com um histórico de desequilíbrio fiscal e instabilidades no poder de compra da moeda, o Brasil experimentou elevadas taxas de juros para financiar seu déficit público e neutralizar as medidas de risco relacionadas à credibilidade do devedor que, no âmbito do Estado, estão relacionadas com o equilíbrio das finanças públicas e a possibilidade do Estado honrar seus compromissos.

Desta forma, se, por um lado, o aumento na taxa básica de juros leva um aumento na captação de investidor estrangeiro e, por conseguinte, um aumento na taxa de câmbio, e uma redução na dívida atrelada à moeda externa, por outro lado este mesmo aumento gera um aumento na dívida pública interna, e uma contração nas operações de crédito (pois reduz a base monetária sobre a qual recai o efeito multiplicador da moeda), reduzindo o ritmo da atividade econômica. ${ }^{191}$

Outrossim, justamente quando a conjuntura econômica é desfavorável e apresenta tendência inflacionária, a taxa SELIC sofre um aumento, uma vez que sua estrutura é composta por taxa de juros reais e correção monetária (vide capítulo 4.2.) o que, por sua vez, gera um aumento no déficit público, tendo em vista serem os títulos da dívida pública a ela atrelados, por conseguinte, provocando uma inconsistência no plano de metas.

\footnotetext{
${ }^{187}$ Índice que mede a variação do custo de cesta de consumo representativa da população com renda até 40 salários mínimos em 12 regiões metropolitanas do país, com projeções de dois anos, e divulgação trimestral

${ }^{188}$ O Relatório de Inflação é o documento divulgado trimestralmente pelo Comitê, que analisa detalhadamente a conjuntura econômica e financeira do País, compreendendo a política creditícia, monetária e fiscal, o nível de atividade, preços e economia internacional, bem como apresenta perspectivas para a taxa de inflação.

${ }^{189}$ O Comitê atua avaliando a tendência futura da inflação: num primeiro momento, é feita análise de conjuntura doméstica, que abrange evolução recente da economia, avaliação prospectiva das tendências da inflação, implementação da política monetária, inflação, atividade econômica, expectativas e sondagens, mercado de trabalho, crédito e inadimplência, ambiente externo, comércio exterior e reservas internacionais, mercado monetário e operações de mercado aberto, em seguida são feitas recomendações acerca da política monetária, para que assim seja realizada a votação e fixada meta para a Taxa SELIC.

${ }^{190}$ Disponível em www.bcb.gov.br, acessado em 20/05/2008.

${ }^{191}$ PARREIRAS, Maria Araujo. A estrutura institucional da dívida pública brasileira e seus impactos sobre a gestão da política monetária: uma análise empírica do regime de metas para a inflação. Ob. cit.
} 
Sobre estas distorções decorrentes da utilização da taxa de juros para a conformação da estrutura da Dívida Pública, e as inconsistências do sistema de metas para inflação, Maria Araujo Parreiras ${ }^{192}$ constata: a) o aumento na taxa SELIC diminui o poder da política monetária para controlar a demanda agregada e, conseqüentemente, a inflação; b) ao aumentar os juros para conter a inflação, há elevação na dívida pública e, por conseguinte, redução da credibilidade do Estado como devedor; c) a redução da credibilidade do Estado pode gerar a desvalorização da moeda e aumentar o nível de preços; d) a influência desta credibilidade na formação da taxa de juros pressiona sua elevação; e) a elevação na SELIC retira parcelas da renda social, gerando a contração do crédito e, por conseguinte, reduzindo a atividade econômica do Estado.

Todavia, estas distorções não decorrem da metodologia quantitativa sobre a qual se fundamentam, mas, do desvio de função dos juros como mecanismo de controle de moeda e de crédito com a finalidade de administrar necessidades de liquidez do Estado, protegendo-se falsamente sob o manto das atribuições de caráter normativo e fiscalizador das autoridades monetárias. Por este motivo é que a solução desta problemática encontrase no plano da legitimidade. 


\subsection{A FIXAÇÃo DA TAXA BÁSICA DE JUROS E O PROBLEMA DE LEGITIMIDADE}

Para o desenvolvimento do presente capítulo, partirei do conceito de legitimidade elucidado por Eros Roberto Grau, in verbis: “a norma jurídica é legítima - dotada de legitimidade - quando existir correspondência entre o comando nela consubstanciado e o sentido admitido e consentido pelo todo social, a partir da realidade coletada como justificadora do preceito normatizado. (...) dotado de legitimidade é o direito posto que corresponde ao direito pressuposto." 193

$\mathrm{O}$ autor prossegue esclarecendo que o fundamento de legitimidade do direito encontra-se na autoridade - como produto do racional relacionamento entre os comandos emitidos pelos que detém o poder e o consenso do grupo social - e que este consenso social é observado na medida em que o direito posto permite o pleno desenvolvimento das forças materiais produtivas, em determinada sociedade.

Desta forma, para que se possa fazer um debate adequado acerca da ilegitimidade do direito posto que regula a fixação da taxa básica de juros, é necessário evidenciar que não apenas tal direito não se coaduna ao sentido admitido e consentido pelo todo social, bem como constitui entrave ao pleno desenvolvimento das forças produtivas ("ocasião em que se instala uma época de revolução social" ${ }^{194}$ ), motivo pelo qual esta discussão apenas é possível sob uma perspectiva macrojurídica.

Para tanto, breves considerações acerca do direito posto, além das já expostas no decorrer do presente trabalho, são necessárias.

Antes da reforma da organização bancária, com a criação do Banco Central do Brasil, as funções de política monetária estavam distribuídas entre vários órgãos da administração pública, que se sujeitavam ao Ministro das Finanças. A função de emissão monetária pertencia ao Tesouro Nacional, cuja distribuição se daria pelo Banco do Brasil, por intermédio da Caixa de Estabilização Bancária e de sua Carteira de Redescontos. A

\footnotetext{
${ }^{193}$ GRAU, 2001, p. 86.

${ }^{194}$ Ibid., p. 89.
} 
função de controle da política monetária era exercida pela Superintendência da Moeda e do Crédito (SUMOC) com atribuição principalmente de controle de crédito, de receber reservas dos bancos particulares e de comprar e vender títulos públicos (neste momento em volume inexpressivo). A função de redesconto era realizada pelo Banco do Brasil, mediante a Caixa de Mobilização Bancária (CAMOB). E as operações financeiras com o exterior ficavam a cargo da Carteira de Câmbio do Brasil (que controlava o mercado de câmbio) e Carteira do Comércio Exterior (que autorizava e fiscalização as importações e exportações). ${ }^{195}$

Com o advento da lei $\mathrm{n}^{\circ} 4.595$ de 31.12.1964, a SUMOC foi substituída pelo Conselho Monetário Nacional (CMN), encarregado de formular a política da moeda e do crédito, objetivando o progresso econômico e social do país (art. $2^{\circ}$ ), cujas principais atribuições importam ressaltar: adaptar o volume dos meios de pagamento (art. $3^{\circ}$, inciso I), regular o valor interno e externo da moeda (art. $3^{\circ}$, inciso II e III), zelar pela liquidez e solvência das instituições financeiras (art. $3^{\circ}$, inciso VI), coordenar as políticas monetária, creditícia, orçamentária, fiscal e da dívida pública, interna e externa, fixar as diretrizes e normas da política cambial (art. $4^{\circ}$, inciso V), disciplinar o crédito em todas as suas modalidades e as operações creditícias em todas as suas formas (art. $4^{\circ}$, inciso VI), limitar, sempre que necessário, as taxas de juros (art. $4^{\circ}$, inciso XI).

Ao lado do CMN, a quem incumbe formular a política da moeda e do crédito, foi instituído o Banco Central do Brasil, com a função precípua de executar esta política, cujas principais atribuições são de: receber os recolhimentos compulsórios de que trata o inciso anterior e, ainda, os depósitos voluntários à vista das instituições financeiras (art. 10 inciso IV), realizar operações de redesconto e empréstimos a instituições financeiras bancárias (art. $10^{\circ}$, inciso V), exercer o controle do crédito sob todas as suas formas (art. $10^{\circ}$, inciso VI), efetuar o controle dos capitais estrangeiros (art. $10^{\circ}$, inciso VII), ser depositário das reservas oficiais de ouro e moeda estrangeira (art. $10^{\circ}$, inciso VIII), efetuar, como instrumento de política monetária, operações de compra e venda de títulos públicos federais (art. $10^{\circ}$, inciso XII).

A fiscalização, administração e controle do déficit público, portanto, não foi atribuída a nenhum destes dois órgãos (CMN ou Banco Central) e sim a Secretaria do 
Tesouro Nacional (STN), instituída por força do Decreto $\mathrm{n}^{\circ} 92.452$ de 10.03.1986. Esta função de controle da dívida pública restava evidenciada pelas atribuições previstas em seu art. 2': "I - controlar as operações: a) realizadas por conta e ordem do Tesouro Nacional; e b) nas quais o Tesouro Nacional figure como mutuário ou financiador; II - controlar as responsabilidades assumidas pelo Tesouro Nacional, em decorrência de contratos de empréstimos e financiamentos (...); III - autorizar os pagamentos necessários à satisfação de compromissos financeiros garantidos pelo Tesouro Nacional (...); V - controlar os valores mobiliários representativos de participação societária da União (...); VI compatibilizar, com os objetivos da execução financeira e orçamentária da União: a) a contratação de operações de crédito externo (...); e b) a contratação ou renovação de operações de crédito interno (....)”.

Verifica-se, a princípio, que essas competências, bem como as demais que se referem a todas as autoridades monetárias sobre as quais recai o controle da moeda e do crédito, justificam-se num plano formal de distribuição do exercício do poder do Estado, do ponto de vista da legalidade. ${ }^{196}$

A despeito da elaboração dos referidos diplomas legais sob a égide das Constituições de 1946 e 1967, respectivamente, a Constituição Federal de 1988, sob o fenômeno da recepção, recebeu todas as normas infraconstitucionais elaboradas anteriormente a ela, sem que a contrariasse materialmente. Desta forma, antes que se perquira acerca dos efeitos econômicos gerados em razão da atuação das autoridades monetárias, é necessário que esta atuação subordine-se aos princípios constitucionais, consubstanciados não só no capítulo da ordem econômica (art. 170), bem como nos princípios fundamentais (art. $3^{\circ}$ ) e decorrentes dos direitos e garantias fundamentais (principalmente art. $5^{\circ}$ ).

Esta primeira consideração é de extrema relevância, na medida em que a autoridade monetária ao atuar em conformidade às atribuições conferidas pelas normas infraconstitucionais, porém de maneira incompatível com a construção de uma sociedade livre, justa e solidária, ou com o desenvolvimento nacional, ou erradicação da pobreza e da marginalização e redução das desigualdades sociais e regionais, ou promoção do bem de

${ }^{196}$ CHIARA, José Tadeu de. A moeda e a ordem jurídica. Ob. cit. 
todos, digo, com qualquer dos princípios consagrados pela Constituição Federal, colhe conseqüências no plano da ilegalidade e, por conseguinte, da inconstitucionalidade.

Quer se dizer com isso que as normas sobre as quais se fundamenta o funcionamento do Sistema Financeiro Nacional não permite que as autoridades atuem apenas adstritas aos limites nelas previstos, pois se assim o fosse, consubstanciariam verdadeira afronta material à Magna Carta. Exemplificativamente, o Conselho Monetário Nacional, ao formular a política da moeda e do crédito, não apenas deve fazê-lo tendo em vista o progresso econômico e social do país, limite previsto no art. $2^{\circ}$, caput, da própria norma infraconstitucional - Lei $\mathrm{n}^{\circ}$ 4.595, mas além, deve objetivar a finalidade de assegurar a todos existência digna, conforme os ditames da justiça social, e os princípios consagrados no art. 170 da Constituição Federal e outros.

A simples leitura dos textos normativos basta para que se verifiquem eventuais incompatibilidades no plano da legalidade, entretanto, no plano da legitimidade, apenas uma análise dos fatos da realidade é necessária para revelar aquilo que é consentido pelo todo social e, por conseguinte, apontar incompatibilidades entre os comandos emitidos pelos que detém o poder e o consenso do grupo social.

Observando a estrutura e o funcionamento do Banco Central do Brasil, a primeira verificação que salta aos olhos diz respeito a exagerada centralização de funções na esfera do poder executivo, decorrente de uma autoridade monetária organizada sob a sombra de um regime ditatorial (observe que a lei $n^{\circ} 4.595$ data de 1964) e, portanto, com a mínima sujeição ao poder legislativo, situação que se agrava pela ausência dum "conjunto de regras que permitam a eficiente gestão e fiscalização das decisões do executivo por outra esfera do poder" e pela "falta de destaque para as questões monetárias que caracterizam o desempenho dos membros de nosso Congresso Nacional"197.

Outrossim, o funcionamento da taxa de juros como mecanismo de controle da moeda e de crédito revela que sua finalidade foi deturpada para atender apenas as necessidades de financiamento da estrutura do Estado. Desde a época das operações de open-market, com juros fixados em patamares que permitissem ao Estado concorrer com particulares na participação da renda social poupada, à época do Plano Real, com juros 
fixados em taxas atrativas para o influxo de recursos internacionais e, até mesmo após a adoção da sistemática de metas para inflação, cuja fixação de juros em altos patamares revelaria de maneira inequívoca as incongruências desta política monetária (vide capítulo 4.4.).

Em abril de 2008, quando aproximadamente 31\% do estoque da Dívida Pública Interna tinham como fator de correção a taxa SELIC, o aumento em 0,5 pontos percentuais (de $11,25 \%$ para $1,75 \%$ ) representaria ao Tesouro Nacional um acréscimo na dívida de $\mathrm{R} \$$ 2,9 bilhões de reais. ${ }^{198}$

$\mathrm{Na}$ medida em que a elevação das taxas de juros provoca o endividamento do Estado, há uma contração de recursos monetários e, por conseguinte, uma restrição na utilização do crédito como mecanismo de política monetária. É aqui que a manipulação destas taxas de juros, ainda que decorrente das atribuições previstas formalmente nos textos normativos, confronta o sentido admitido e consentido pelo todo social, uma vez que estes mecanismos de controle justificam-se apenas na medida em que são utilizados para instrumentar a moeda e o crédito:

"A combinação dessas finalidades" (função desempenhada pelos títulos de dívida pública de controle quantitativo do crédito e de ajuste a liquidez do mercado) "deve ser presidida por um sistema de decisão que assegure a predominância dos interesses coletivos presentes nas categorias que atuam nos mercados, sobre os individuais de setores privados, ou do próprio governo." 199

Nesta exegese, inclusive o direito positivo sobre o qual se fundamentam as competências do Banco Central e da Secretaria do Tesouro Nacional servem como parâmetro para uma análise do que o todo social quis admitir e consentir, ou seja, ao Banco Central foram conferidas atribuições de controle da moeda e de fixação da taxa de juros, com o objetivo de controlar a base monetária, as instabilidades do poder de compra da moeda, e a oferta de crédito, enquanto que ao Tesouro foram conferidas atribuições de

\footnotetext{
${ }^{198}$ Disponível em www.tesouro.fazenda.gov.br, acessado em 17/08/2008.

${ }^{199}$ CHIARA, José Tadeu de. A moeda e a ordem jurídica. Ob. cit., p. 107.
} 
administrar a dívida pública; ocorre que a utilização da taxa de juros como se dá hodiernamente é incompatível com tais atribuições, porque se por um lado a fixação da taxa de juros em altos patamares pode ser utilizada como medida de controle de instabilidade do poder de compra da moeda, por outro lado acarreta um aumento na dívida pública.

De todo o exposto, conclui-se, pois, que a manipulação da taxa básica de juros como hoje é feita, a despeito de conformada aos limites dos textos normativos que regulam o sistema financeiro, revela a ilegitimidade da atuação do Estado, decorrente do desvio de função dos mecanismos de controle da moeda e do crédito para administrar suas necessidades de liquidez. 


\section{CAPÍTULO 5. CONCLUSÃO}

1. O negócio jurídico de crédito não se confunde com o negócio jurídico a crédito e com o negócio jurídico de mútuo.

2. Este negócio de crédito, ou negócio financeiro, decorre da atividade de intermediação financeira - pela qual se operacionaliza o suprimento de recursos monetários para instrumentar consumo ou investimento, a partir de recursos tomados junto ao público - e consubstancia-se num negócio de natureza contratual ou cambiária, em que prestação e contraprestação cumprem-se pelo fornecimento de moeda, colhendo efeitos para além da relação jurídica bilateral contratada entre tomador e instituição financeira.

3. É a partir do crédito que se torna possível a antecipação do resultado do produto social, permitindo a ampliação da renda (em sua forma monetária), antes mesmo que se altere o conjunto de bens e serviços produzidos (em sua forma física) pela atividade econômica do Estado.

4. Uma vez que as disponibilidades monetárias orientam-se em função das motivações de liquidez, o juro será o instrumento pelo qual se viabilizará a manipulação da atividade econômica do Estado.

5. O juro decorre da comparação entre diferentes situações de liquidez, e se expressa em razão da equivalência entre as disponibilidades monetárias, da preferência pela liquidez e da eficiência marginal dos capitais.

6. A preferência pela liquidez motiva-se em razão da renda, do negócio, da precaução e da especulação, sendo este último o motivo que revela que os recursos para instrumentar consumo ou investimento em direção aos particulares se ajustam em função da participação do Estado na renda social.

7. Assim, o equivalente no juro se completa a) pelo interesse da coletividade (que no âmbito individual traduz o sentimento de egoísmo que orienta a opção de buscar da melhor forma a satisfação de sua necessidade em condições vantajosas); b) pelas relações de mercado (decorrente das disponibilidades monetárias, da preferência pela liquidez e da 
eficiência marginal dos capitais); c) pelo tempo; e d) pela participação do Estado na renda social.

8. Donde se conclui que a disciplina jurídica do juro deve adequar-se de forma a assegurar o equilíbrio constante do preço pela renúncia a liquidez, enquanto perdurar o negócio e, além, em função dos mecanismos de controle da moeda e do crédito, levando em consideração toda a atividade econômica do Estado.

9. A perspectiva história acerca da matéria elucida que as funções dos juros foram reformuladas à medida que se reformulavam as funções do crédito.

10. Classificam-se os juros quanto à natureza em remuneratórios e moratórios. Aqueles, frutos civis, devidos desde a contratação até o vencimento da obrigação, estes, penalidade pecuniária, devidos após o vencimento da obrigação.

11. Quanto à forma de cálculo, classificam-se em simples ou compostos. Aqueles quando incidirem apenas sobre o valor principal, sem que incidam novos juros a cada período que se conte, este quando somados ao capital em cada período para cálculo de novos juros nos períodos subseqüentes.

12. A prática do anatocismo vedada pelo Decreto-Lei 22.626, por força de seu art. $4^{\circ}$, proíbe que se contem juros de juros em período inferior a um ano, donde se colhe que será permitido: i) contar juros de juros anualmente ii) contar juro de juro quando previstos em lei especial (como ocorre nos financiamentos mediante cédulas de crédito rural, industrial e comercial, nos termos do art. $5^{\circ}$ do Decreto-Lei 167/67 e Súmula 93 do STJ, nas Cédulas de Crédito Bancário, nos termos do art. 28, § $1^{\circ}$ da Lei 10.931/2.004) e iii) contar juro de juro nos casos em que o Conselho Monetário Nacional deliberar no exercício da competência do art. $4^{\circ}$ da Lei 4.595/1964.

13. A vedação ao anatocismo não se refere a prática de juros compostos, pois aquele diz respeito a forma de cobrança enquanto este, a forma de cálculo.

14. Sobre a Medida Provisória 2.170, de 23.8.01 que permitiu a capitalização de juros em período inferior a um ano, em operações realizadas por instituições integrantes do Sistema Financeiro Nacional, foram refutados os argumentos enumerados em sede de ADIn 2316/DF acerca de sua inconstitucionalidade formal e material. 
15. A análise da comissão de permanência revelou seu caráter de juros remuneratórios devidos após o vencimento da obrigação, apenas quando fundamentado num negócio jurídico de crédito, não se confundindo, pois, com juros moratórios ou correção monetária.

16. São acumuláveis: i) juros remuneratórios e juros moratórios; ii) juros remuneratórios e comissão de permanência; iii) juros moratórios e comissão de permanência; iv) comissão de permanência e correção monetária.

17. Em se tratando das taxas praticadas no negócio financeiro, a limitação dos juros remuneratórios se dá em função da noção de equivalência entre as diferentes situações de liquidez, devendo levar em conta, portanto, para sua composição: i) o interesse da coletividade (traduzido pelo sentimento de egoísmo que orienta a opção de buscar da melhor forma a satisfação de sua necessidade em condições vantajosas); ii) as relações de mercado (expressos nas motivações de liquidez, em razão das disponibilidades monetárias e da eficiência marginal dos capitais) e; iii) a participação do Estado (ora como agente econômico, concorrendo com particulares na participação da renda social poupada, ora como autoridade monetária, orientando decisões de consumo e investimento).

18. Por este motivo, concluiu-se que a limitação da taxa de juros em termos nominais confronta a vertente dinâmica que o ordenamento jurídico pretende tutelar, cujo conteúdo está previsto nos princípios do equilíbrio econômico-financeiro e da vedação ao enriquecimento sem causa.

19. A taxa básica de juros é a taxa que reflete a expectativa de renda do capital para os empréstimos bancários, praticada no mercado, que tenha como lastro títulos públicos federais negociados no Sistema Especial de Liquidação e Custódia, composta por juros reais e uma taxa de inflação no período considerado, motivo pelo qual para o cálculo de perdas e danos nos termos do art. 404 do Código Civil, a taxa de juros fixadas em função da SELIC é inacumulável com a correção monetária, sob pena de configurar bis in idem.

20. Outrossim, foi constatada a constitucionalidade da cobrança da taxa básica de juros a título de juros moratórios decorrentes do crédito tributário, pela análise detalhada dos princípios da anterioridade tributária, da legalidade tributária e da indelegabilidade de competência tributária. 
21. Finalmente, um estudo sobre a fixação da taxa básica sob uma perspectiva macrojurídica revelou seu papel fundamental no encaminhamento do fluxo monetário, influenciando de maneira decisiva o crédito e, por conseguinte, a atividade produtiva do Estado.

22. A despeito desta constatação, uma análise dos efeitos colhidos no plano da ordem social decorrentes da manipulação da taxa básica de juros evidenciou, por um lado, que o Estado passou a utilizar este mecanismo com o principal objetivo de financiar sua estrutura e, por outro, que a elevação de seus patamares provoca um endividamento público em razão da composição da Dívida Pública.

23. Concluiu-se, portanto, que esta manipulação confronta com o sentido admitido e consentido pelo todo social, seja porque implica numa contração de recursos monetários e, por conseguinte, na restrição da utilização do crédito como mecanismo de política monetária, seja porque as atribuições previstas no ordenamento jurídico justificam-se apenas em razão dos mecanismos de controle da moeda e crédito.

24. Desta forma, se conclui que a manipulação da taxa básica de juros como hoje é feita, a despeito de conformada aos limites dos textos normativos que regulam o sistema financeiro, revela a ilegitimidade da atuação do Estado, decorrente do desvio de função dos mecanismos de controle da moeda e do crédito para administrar necessidades de liquidez do Estado. 


\section{REFERÊNCIAS PRIMÁRIAS (JURISPRUDÊNCIA)}

\section{SUPREMO TRIBUNAL FEDERAL (STF)}

Ação Direta de Inconstitucionalidade 004-DF

Ação Direta de Inconstitucionalidade 4-7/DF

Ação Direta de Inconstitucionalidade 162-1/DF

Ação Direta de Inconstitucionalidade 493-DF

Ação Direta de Inconstitucionalidade 2316-DF

Ação Direta de Inconstitucionalidade 2591/DF

Recurso Extraordinário 100336/PE

Recurso Extraordinário 103051/SP

Súmula 121

Súmula 596 


\section{SUPERIOR TRIBUNAL DE JUSTIÇA (STJ)}

Agravo Regimental no Recurso Especial 440182/RS 2002/0065631-8, Relator(a) Ministro Ari Pargendler, Órgão Julgador: Terceira Turma, Data do Julgamento 18/08/2005.

Agravo Regimental no Agravo 562712/RS, Relator Ministro Humberto Gomes de Barros, Órgão Julgador Terceira Turma, Data do Julgamento 30/11/2004.

Agravo Regimental no Recurso Especial 604470-RS, Relator Ministro Castro Filho Órgão julgador: Terceira Turma, Data do julgamento: 10/9/2007.

Agravo Regimental no Recurso Especial 609257/RS, Relator Ministro César Asfor Rocha, Órgão Julgador Quarta Turma, Data do Julgamento 07/10/2004.

Agravo Regimental no Recurso Especial 682884 - RS 2004/0119457-4, Relator Ministro Ari Pargendler, Órgão Julgador: Terceira Turma, Data do julgamento: 02/08/2005.

Agravo Regimental no Recurso Especial 706368/RS, 2004/0169391-0 Relatora Ministra Nancy Andrighi, Órgão Julgador: Segunda Seção do STJ, Data do Julgamento $27 / 04 / 2005$.

Agravo Regimental no Recurso Especial 801072/RS, 2005/0198163-0 Relator Ministro Aldir Passarinho Junior, Órgão Julgador: Quarta Turma, Data do Julgamento: 07/03/2006.

Agravo Regimental no Recurso Especial 921815-RS, Relator Ministro Carlos Alberto Menezes Direito, Órgão julgador: Terceira Turma, Data do julgamento 8/11/2007.

Agravo Regimental no Recurso Especial 973549-RS, Relator Ministro Hélio Quaglia Barbosa, Órgão Julgador: Quarta Turma, Data do julgamento 26/11/2007. 
Argüição de Inconstitucionalidade no Recurso Especial 215881 (1999/0045345-0 08/04/2002), Relator Ministro Franciulli Netto, Órgão Julgador: Segunda Turma, Data do julgamento: 098/04/2002).

Recurso Especial 103051/SP, Relator Ministro Rafael Mayer, Órgão Julgador: Primeira Turma, Data do julgamento: 16/11/1984.

Recurso Especial 1061530 - RS (2008/0119992-4), Relator Ministro Ari Pargendler, Órgão julgador: Segunda Seção do STJ, Data do julgamento: 22/10/2008.

Recurso Especial 271214 - RS (2000/0079249-7), Relator Ministro. Ari Pargendler, Órgão julgador: Segunda Seção do STJ, Data do julgamento: 12/03/2003.

Recurso Especial 402483 (2002/0000391-4 - 05/05/2003), Relator Ministro Castro Filho, Órgão Julgador Segunda Seção do STJ, Data do Julgamento 26/03/2003.

Recurso Especial 627511/GO 2004/0013338-7, Relator(a) Ministro Aldir Passarinho Junior, Órgão Julgador Quarta Turma, Data do Julgamento 13/12/2005.

Súmula 07

Súmula 30

Súmula 93

Súmula 294

Súmula 295

Súmula 296 
TRIBUNAL DE JUSTIÇA DO ESTADO DE SÃO PAULO (TJ-SP)

Agravo de Instrumento 1170899- 0/6, Relator: Adilson de Araújo, Comarca: Teodoro Sampaio Órgão julgador: $31^{\mathrm{a}}$ Câmara de Direito Privado, Data do julgamento: 03/06/2008, Data de registro: 04/06/2008.

Apelação 1190489100, Relator(a): João Camillo de Almeida Prado Costa, Comarca: São Paulo, Órgão julgador: $19^{\mathrm{a}}$ Câmara de Direito Privado, Data do julgamento: 10/11/2008, Data de registro: 14/01/2009.

Apelação 1248480700, Relator(a): Moura Ribeiro, Comarca: Santos, Órgão julgador: $11^{\mathrm{a}}$ Câmara de Direito Privado, Data do julgamento: 17/12/2008, Data de registro: $16 / 01 / 2009$.

Apelação 7000322800, Relator(a): João Camillo de Almeida Prado Costa, Comarca: São Paulo, Órgão julgador: $19^{a}$ Câmara de Direito Privado, Data do julgamento: 15/12/2008, Data de registro: 14/01/2009.

Apelação 7102052100, Relator(a): Renato Siqueira De Pretto, Comarca: São Paulo Órgão julgador: $21^{a}$ Câmara de Direito Privado, Data do julgamento: 19/11/2008, Data de registro: 01/12/2008.

Apelação 7168980200, Relator(a): Irineu Fava, Comarca: Praia Grande, Órgão julgador: $13^{a}$ Câmara de Direito Privado, Data do julgamento: 26/11/2008, Data de registro: $15 / 01 / 2009$.

Apelação 7206752400, Relator(a): Maia da Rocha, Comarca: Rancharia, Órgão julgador: $17^{\mathrm{a}}$ Câmara de Direito Privado, Data do julgamento: 22/09/2008, Data de registro: 01/12/2008.

Apelação 7236587600, Relator(a): Salles Vieira, Comarca: Ribeirão Preto, Órgão julgador: 24a Câmara de Direito Privado, Data do julgamento: 06/11/2008, Data de registro: 16/01/2009. 
Apelação 7245329300, Relator(a): Gilberto dos Santos, Comarca: Osasco, Órgão julgador: $11^{a}$ Câmara de Direito Privado, Data do julgamento: 19/06/2008, Data de registro: 30/06/2008.

Apelação 7253762300, Relator(a): Gilberto dos Santos, Comarca: Avaré Órgão julgador: $11^{\mathrm{a}}$ Câmara de Direito Privado, Data do julgamento: 14/08/2008, Data de registro: 22/08/2008.

Apelação 72566586, Relator: Paulo Pastore Filho, Comarca: Itu, Órgão julgador: $17^{\text {a }}$ Câmara de Direito Privado, Data do julgamento: 08/09/2008, Data de registro: 03/10/2008.

Apelação 7301655200, Relator(a): Luiz Sabbato, Comarca: São Paulo, Órgão julgador: $13^{\mathrm{a}}$ Câmara de Direito Privado, Data do julgamento: 26/11/2008, Data de registro: 13/01/2009.

Apelação Com Revisão 1014015100, Relator(a): Nilza Bueno da Silva, Órgão julgador: $21^{\mathrm{a}}$ Câmara de Direito Privado, Data do julgamento: 12/06/2006, Data de registro: 26/06/2006.

Apelação Com Revisão 3173174800, Relator(a): Natan Zelinschi de Arruda, Comarca: São Paulo, Órgão julgador: $7^{\mathrm{a}}$ Câmara de Direito Privado, Data do julgamento: 17/12/2008, Data de registro: 15/01/2009.

Apelação Com Revisão 970713009, Relator(a): Emanuel Oliveira, Comarca: São José dos Campos, Órgão julgador: $34^{\mathrm{a}}$ Câmara de Direito Privado, Data do julgamento: 03/10/2007 Data de registro: 05/10/2007.

Apelação Com Revisão 755791900. Relator(a): Benedito Roberto Garcia Pozzer Comarca: Cabreúva Data do julgamento: 30/11/2005 Data de registro: 07/12/2005.

Apelação Com Revisão 7267198200, Relator(a): Zélia Maria Antunes Alves, Órgão julgador: $13^{\mathrm{a}}$ Câmara de Direito Privado, Data do julgamento: 12/11/2008, Data de registro: $28 / 11 / 2008$. 
Embargos Infringentes 975320601, Relator(a): Ricardo Negrão, Comarca: São Paulo, Órgão julgador: 19a Câmara de Direito Privado, Data do julgamento: 24/11/2008, Data de registro: 14/01/2009. 
TRIBUNAL DE JUSTIÇA DO RIO GRANDE DO SUL (TJ-RS)

Apelação 196006639, Relator: Márcio Oliveira Puggina, Órgão julgador: Quarta Câmara Cível, Data do julgamento: 11/04/1996. 


\section{REFERÊNCIAS SECUNDÁRIAS (BIBLIOGRAFIA)}

\section{LIVROS}

ALTAVILA, Jayme de. Origem dos Direitos dos Povos. 2ed. São Paulo: Melhoramentos, 1987.

ARISTÓtEleS, 384-322 a.C. Política. Madrid: Comp Ibero-Americana de Publicaciones, 19-?

ASCARELLI, Tulio. Obbligazioni pecuniarie. Bologna: Zanichelli, 1959.

BACHA, Carlos José Caetano. Macroeconomia aplicada `a análise da economia brasileira. São Paulo: Universidade de São Paulo, 2004.

BALEEIRO, Aliomar. Uma introdução à ciência das finanças. 14ed. Rio de Janeiro: Forense, 1990.

BASTOS, Celso Ribeiro. Comentários à Constituição do Brasil. 2ed, Saraiva, São Paulo, 2000.

BERGER, Pierre. A Moeda e seus Mecanismos. São Paulo: Difusão Européia do Livro, 1967.

BOBBIO, Norberto. Teoria da Norma Jurídica. São Paulo: Edipro, 2001.

BRAVO, Ramon Herrera. Usurae, problematica juridical de los intereses enderecho romano. Jaen: Universidad de Jaen, 1997 apud SCAVONE Junior, Luiz Antonio. Juros no direito brasileiro. São Paulo: Editora Revista dos Tribunais, 2003.

CANARIS, Claus- Wilhelm. Pensamento sistemático e conceito de sistema na ciência do Direito. 3ed. Lisboa: Fund Calouste Gulbenkian, 1989.

CARNELUTTI, Francesco. Teoria generale del diritto. Roma: Soc. ed. del "Foro italiano", 1940. 
DALTON, Hugh. Princípios de finanças públicas. 2ed. Rio de Janeiro: Fundação Getúlio Vargas, 1970.

D’Auria, Francisco. Matemática Financeira e Atuarial. 4ed. São Paulo: São Paulo, 1962.

FISHER, Irving. Le pouvoir d'achat de la monnaie. Paris: M. Giard, 1926.

GRAU, Eros Roberto. Elementos do Direito Econômico. São Paulo: Editora Revista dos Tribunais, 1981.

O direito posto e o direito pressuposto. 4ed. São Paulo: Malheiros, 2001.

GUDIN, Eugenio. Princípio de Economia Monetária. Rio de Janeiro: Agir, 1956.

HUBERMAN, Leo. História da Riqueza do Homem. 9ed. Rio de Janeiro: Zahar 1973 ,

HUGON, Paul. A Moeda: introdução à análise e às políticas monetárias e à moeda no Brasil. 2ed. São Paulo: Livraria Pioneira, 1972.

JHERING, Rudolf Von. Evolução do direito. S.l. : S.N., 19-?

KEYNES, John Maynard. Teoria Geral do Emprego, do Juro e da Moeda. 1ed. São Paulo: Atlas, 1982.

MARTINS, Fran. Títulos de crédito. Rio de Janeiro: Forense, 1998.

MATHIAS, Washington Franco. Matemática Financeira. 5ed. São Paulo: Atlas, 2008.

MEIRELLES, Hely Lopes. Direito Administrativo Brasileiro. 28ed. São Paulo: Malheiros, 2003.

MENDONÇA, Manoel Inácio Carvalho de. Doutrina e prática das obrigações. Tomo II. 2ed. Rio de Janeiro: Freitas Bastos, 1956. 
MIRANDA, Pontes de. Tratado de Direito Privado. Parte Geral. Tomo III. Rio de Janeiro: Borsoi, 1971.

. Tratado de Direito Privado. Parte Geral. TomoVI. Rio de Janeiro: Borsoi, 1954-1969.

. Tratado de Direito Privado. Parte Especial. Tomo XXIV.

3ed. Rio de Janeiro: Borsoi. 1971.

- Tratado de Direito Privado: negócios jurídicos. Parte especial. Tomo XXXVIII. Rio de Janeiro: Borsoi, 1962.

Tratado de Direito Privado. Parte Especial. Tomo XLII.

Rio de Janeiro: Borsoi. 1971.

MONTESQUIEU. O espírito das leis. v2. São Paulo: Cultura, 1945.

MORAES, Alexandre de. Direito Constitucional. 11ed. São Paulo: Atlas, 2002.

NUSSBAUM, Arthur. Teoría jurídica del dinero. Madrid: V. Suárez, 1929.

REALE, Miguel. Lições Preliminares de Direito. São Paulo: J. Bushatsky, 1974.

RIZZARDO, Arnaldo. Contratos de crédito bancário. 5ed. São Paulo: Revista dos Tribunais, 2000.

SAVIGNY, Friedrich Karl Von. Metodología jurídica. Buenos Aires: Depalma, 1979

SCAVONE Junior, Luiz Antonio. Juros no direito brasileiro. São Paulo: Editora Revista dos Tribunais, 2003.

SCHUMPETER, Joseph A. Teoria do desenvolvimento econômico. Rio de Janeiro: Fundo de Cultura, 1961.

TELLES JR, Goffredo. O Direito Quântico. 3ed. São Paulo: Max limonad, 19?

THOMAS DE AQUINO, Santo. Suma Teológica. Madrid: Moya Y Plaza, 1880. 
VIEIRA SOBRINHO, José Dutra. Matemática Financeira. São Paulo: Atlas, 1989.

VIDIGAL, Geraldo de Camargo. Teoria Geral do Direito Econômico. São Paulo: Revista dos Tribunais, 1977.

Fundamentos do Direito Financeiro. São Paulo: Revista dos Tribunais: 1973.

WEBER, Max. A Ética Protestante e o Espírito do Capitalismo. 15ed. São Paulo: Pioneira, 2000.

WICKSELL, Knut. Lectures of political economy. London: Routledge \& Kegan Paul, 1934 apud GUDIN, Eugenio. Princípio de Economia Monetária. Rio de Janeiro: Agir, 1956. 


\section{ARTIGOS, PERIÓDICOS E TRABALHOS PUBLICADOS}

BENTHAM, Jeremy. Défense de L'Usure e Lettres sur lês Inconvenients dês Lois que Fixent lês taux de l'Intérêt de l'Argent. Malrer et Compagnie, Paris, 1828 apud VIDIGAL, Geraldo de Camargo. Teoria Geral do Direito Econômico. São Paulo, Editora Revista dos Tribunais, 1977.

BULGARELli, Waldirio. A mora e a resolução 1.129 do Banco Central. Revista de Direito Mercantil, São Paulo, ano XXVI, n. 67, p. 71-81, jul-set, 1987.

CHIARA, José Tadeu de. Disciplina jurídica das instituições financeiras. Revista de Direito Público, São Paulo, v. 41/42, p. 289-307, 1977.

Operações de credito: disciplina das obrigações. Revista de Direito Público, São Paulo, v. 49/50, p. 303-311, 1979.

MUNIZ, Francisco José Ferreira. Confronto de comissão de permanência e de correção monetária. In: Simpósio sobre as condições gerais dos contratos bancários e a ordem pública econômica, 1988, Paraná. Anais Jurídicos I... Paraná: Juruá, 179p, p. 75-79, 1988.

OLIVEIRA, Marcos Cavalcante de. Comissão de permanência: legalidade e necessidade. Revista de Direito Bancário, São Paulo, ano 9, n. 33, p. 33-60, jul-set 2006.

R.H.TAWNER; E. POWER. Tudor Economic Documents. Compilação. Londres: Longmans, Green and Company, 1924, vol II, p. 142, apud Leo Huberman. História da Riqueza do Homem. 9. ed. Rio de Janeiro: Zahar 1973.

SOBRINHO, Ruy Cunha. Inadmissiblidade de cobrança da comissão de permanência pela via executiva. In: Simpósio sobre as condições gerais dos contratos bancários e a ordem pública econômica, 1988, Paraná. Anais Jurídicos I... Paraná: Juruá, 179p, p. 101-102, 1988. 
VIDIGAL, Geraldo de Camargo. Taxas de Juros, no Brasil. Revista do Direito Bancário, do Mercado de Capitais e da Arbitragem, São Paulo, v. 3, n. 10, p. 35-43, outdez. 2000. 


\section{DISSERTAÇÕES E TESES}

CAPUCHO, Fábio Jun. O enriquecimento sem causa no Código Civil Brasileiro. 184p. Dissertação (Mestrado em Direito) - Faculdade de Direito, Universidade de São Paulo, São Paulo. 2007.

CHIARA, José Tadeu de. A moeda e a ordem jurídica. 217p. Tese (Doutorado em Direito) - Faculdade de Direito, Universidade de São Paulo, São Paulo. 1986.

HARFUCH, Leila. Determinantes da Taxa de Juros Nominal e sua relação com a taxa de câmbio no Brasil no período de 1990 a 2006. 209p. Tese (Doutorado em Economia) - Faculdade de Economia, Universidade de São Paulo, São Paulo. 2008.

MOURA, Cristiane Angélica. Contéudo dos requisitos para resolução dos contratos por onerosidade excessiva da prestação no novo Código Civil. 150p. Dissertação (Mestrado em Direito) - Faculdade de Direito, Universidade de São Paulo, São Paulo, 2007.

PARREIRAS, Maria Araujo. A estrutura institucional da dívida pública brasileira e seus impactos sobre a gestão da política monetária: uma análise empírica do regime de metas para a inflação. 154p. Dissertação (Mestrado em Economia) Faculdade de Economia, Universidade de São Paulo, São Paulo. 2007.

POLICANO, Rodrigo Mantovani. A sensibilidade da política monetária no Brasil: 1995-2005. 97p. Dissertação (Mestrado em Economia) - Faculdade de Economia, Universidade de São Paulo, São Paulo. 2006.

SALOMÃO NETO, EDUARDO. Atividade privativa de instituição financeira. 208p. Tese (Livre Docência) - Faculdade de Direito, Universidade de São Paulo, São Paulo. 1998. 


\section{INTERNET}

www.stj.jus.br

www.stj.gov.br

www.tj.gov.br

www.tesouro.fazenda.gov.br

www.bcb.gov.br

www.presidencia.gov.br

www.in.gov.br

www.teses.usp.br

www.usp.br/sibi

www.febraban.org.br 